Est Ag 54 (2019) 269-428

\title{
Imágenes chinas de historia sagrada
}

Blas Sierra de la Calle, osa

Resumen: Esta investigación, estructurada en dos partes, estudia 381 imágenes cristianas chinas. La primera parte es la ambientación histórica. Se comienza mostrando las diversas formas de cristianismo en China -nestoriano, católico, protestante-, para seguir haciendo una breve presentación de los agustinos en China. Sigue el estudio sobre el desarrollo de la imprenta en China, y de la imprenta católica, protestante y de los agustinos en la China de la primera mitad del siglo XX. Seguidamente, se reflexiona sobre la importancia de la imagen y se analizan los principales modelos iconográficos que han servido en China para la publicación de los libros cristianos ilustrados para la catequesis: los grabados europeos, la Biblia de Nadal, las láminas del Antiguo y Nuevo Testamento de Julius Schnorr von Carolsfeld, la Historia Sagrada del Antiguo y Nuevo Testamento de Ignaz Schuster y la obra francesa Catecismo en imágenes. En la segunda parte se estudian con detalle las tres obras chinas objeto de este estudio, que forman parte de los fondos del Museo Oriental y de la Biblioteca del Estudio Teológico Agustiniano. La primera de ellas es "La Historia Sagrada" publicada en 1920, con 82 grabados en blanco y negro. La segunda es el "Catecismo Chino en láminas policromadas", impreso hacia 1925, con veinte láminas en color. Se indica cómo una parte está inspirada en modelos europeos y otra es obra de factura e inspiración china. La tercera obra que se estudia es "La historia más famosa", una vida de Jesús en colores impresa en Shanghai en 1950, escrita por Chen Wanlin y dibujada por Chen Guanyi. Esta publicación en dos tomos consta de 279 cromolitografías. Cada página lleva un pequeño texto chino en la parte derecha del diseño y otro texto en la parte superior, que hacen alusión a la escena representada. La temática de los grabados es, fundamentalmente, la vida de Jesús, desde su nacimiento hasta su ascensión al cielo y, brevemente, los inicios de la vida de la Iglesia 
primitiva y las persecuciones. Sintéticamente, algunas de las cromolitografías representan varios de los aspectos culturales promovidos por la religión católica en China. Se concluye la obra dedicando un diseño a cada uno de los siete sacramentos cristianos. El estudio se completa con 88 ilustraciones en color que hacen referencia al texto.

Palabras claves: Catecismos chinos, Imágenes religiosas, Historia Sagrada.

Abstract: The research, divided in two parts, study 381 Christian Chinese images. The first part present the background to understand the works that are the main subject of these work. Start showing the different forms of Christian faith in China -Nestorians, Catholics, Protestants- and the missionary work of the Augustinians friars there. Next, is the development of the printing press in China making reference to the engravings in colour and the antichristian propaganda, and also the printing press of the Catholic, Protestants and Augustinians in the first half of XX Century China. Later, speaks about the important role of the images and the main artistic models that were used in China in the publication of the books about the Christian faith: European engravings, the Bible of Nadal, the designs of the Old and New Testament of Julius Schnorr von Carolsfeld, the Sacred History of Ignaz Schuster, and the French work "Catechism in Pictures". In the second part, are studied in detail three Chinese illustrated publications that exist in the Library of Museo Oriental and the Augustinian Convent of Valladolid. The first one, "The Holy History", published in 1920, presents 82 engravings in black and white of the Old and New Testament, showing the European sources of inspiration. The second one is the "Chinese Catechism with colour illustrations", published about 1925, where can be seen 20 stories of the Old and New Testament, the Church, death, judgement, purgatory, hell and glory. The third publication is "The most famous History" about the life of Jesus, published in Shanghai in 1950. Was written by Chen Wanli and the artist Chen Guanyi did the 279 colour designs presenting the life of Jesus, the persecution of the early church, the Christian faith promoting art and culture and the seven sacraments. The study is completed with 88 colour illustrations related with the text.

Key Words: Chinese Cathechism, Religious Images, Sacred History

Al principio era la imagen. En el paleolítico los hombres primitivos aprendieron a pintar antes que a escribir. En la China antigua, entre el año 8.000 al 3.000 a. C. los antiguos chinos comenzaron a representar diseños 
que reproducían la realidad que les circundaba. Habían nacido los "pictogramas”. Más tarde, en el llamado periodo arcaico, entre el 3.000 al 1.600 a. C., se pasará de los "pictogramas" a los "ideogramas", de los símbolos directos a los indirectos, colmando el vacío que los primeros dejaban ante un concepto abstracto. Posteriormente, hasta la dinastía Han (202 a. C. 220 d. C.) la escritura completa su evolución y se desarrollan los estilos principales ${ }^{1}$. Se había realizado el paso definitivo de la pintura a la escritura.

Un autor chino, Sun Congtian (c. 1680-1759) escribió en su obra "Cangshu Jiyao" (Manual del Librero) que "Los libros son el tesoro más valioso del mundo. Pues es en los libros donde encontramos discriminado el bien y el mal en la naturaleza humana, y los puntos débiles y fuertes en el mundo"2.

Si esto es verdad para los libros en general, es doblemente cierto si lo referimos a libros con imágenes, pues estas últimas tienen por sí mismas una mayor fuerza de persuasión que la palabra escrita. De ahí la importancia de los libros ilustrados para todo proceso de enseñanza, propaganda, adoctrinamiento o catequesis.

A lo largo de la historia del cristianismo -desde sus orígenes hasta la actualidad- las imágenes han sido siempre un medio privilegiado para expresar la fe y, al mismo tiempo, para difundirla.

\section{PRIMERA PARTE: AMBIENTACIÓN HISTÓRICA}

\section{A.- EL CRISTIANISMO EN CHINA}

El cristianismo fue introducido en China en tres formas distintas: nestoriana, católica y protestante.

\section{a).- Las diversas formas de cristianismo}

El cristianismo nestoriano llegó a China desde Persia, en el año 631, gracias a un personaje llamado Olopan, que se estableció en Chang'an (mo-

\footnotetext{
${ }^{1}$ FAzZIoli, Edoardo, Caratteri cinesi. Dal disegno all'idea. 214 caratteri per comprendere la Cina, Arnaldo Mondadori Editore, Milano 1986, p. 11; Moore, Oliver, Chinese, University of California Press, Berkeley Los Angeles 2000, pp. 15-16.

${ }^{2}$ Citado por: ReEd, Christopher, Gutenberg in Shanghai. Chinese Print Capitalism (1876-1937) UBC Press, Vancouver-Toronto, 2004, p. 5.
} 
derna Xian), la capital cosmopolita de la dinastía Tang (618-906). La célebre estela de Xian, del siglo VIII confirma esta presencia cristiana.

La presencia del cristianismo católico se inicia con los viajes de los franciscanos Giovanni da Pian del Carpine en 1245, y el de Guillermo de Rubruck en 1253. En 1289 el papa Nicolás IV envió a la corte de Kublai Khan al franciscano Giovanni da Montecorvino, que se estableció en Pekín en 1293. En 1307 Pekín se convertiría en archidiócesis y G. de Montecorvino sería su primer arzobispo. En 1327 el también franciscano Odorico da Pordenone, visitó Pekín. La narración de su viaje continuaba y completaba el libro de Marco Polo.

Tras un periodo de estancamiento, en 1575 viaja a China la primera embajada española, presidida por el agustino P. Martín de Rada, que escribirá una relación de su viaje, el primer documento en español sobre el País del Centro.

Entre todas las órdenes religiosas, los jesuitas fueron quienes consiguieron mayores éxitos. Fueron admirados por los chinos por sus conocimientos matemáticos, científicos y tecnológicos. Destacaron el P. Matteo Ricci, que se estableció en Pekín en 1601; el P. Adam Shall von Bell (15911666) que será nombrado director del Observatorio Astronómico de Pekín; el P. Ferdinand Verbiest, que le sucederá en 1669.

En el siglo XVIII la polémica de los llamados "ritos chinos" llevará a la prohibición de las actividades de los misioneros católicos. Años después, en 1724, un decreto del emperador Yongzheng vetó el cristianismo en China y expulsó a la mayor parte de los misioneros. Esta prohibición será levantada solo en 1846.

La tercera forma de cristianismo que llegó a China fue la protestante, por obra de los comerciantes ingleses y holandeses, residentes en Cantón y Macao en el siglo XVIII. Pero el primer misionero protestante que llegó a China fue Robert Morrison enviado a Guangzhou en $1807^{3}$.

\footnotetext{
${ }^{3}$ Una visión global de la historia del cristianismo en China puede encontrarse en las siguientes obras: LATOURETTE, Kenneth Scout, A History of Christian Missions in China, Ch'eng Wen Publishing Company, Taipei 1975; CARY-Elwes, Columba, China and the Cross. Studies in Missionary History, Longmans, Green and Co. London, New York, Toronto 1957; WoLfERSTAN, Bertram, The Catholic Church in China from 1860 to 1907, Sands \& Company, St. Louis, 1909; Laurentin, René, Cina e cristianesimo. Al di lá delle occasioni mancate, Citta Nuova, Roma 1981; BAYs, Daniel H., (Edit) Christianity in China. From the Eighteenth Century to the Present, Stanford University Press, Stanford 1996; CHOng, Alan (Edit.) Christianity in Asia. Sacred Art and visual Splendor, Asian Civilisation Museum, Singapore 2016. pp. 136-169.
} 
En el siglo XIX renacerá la fe cristiana. Los misioneros católicos y protestantes -que eran ya 1300 en 1890-, fundaron escuelas, hospitales, orfanatos, asilos, imprentas y otros proyectos que contribuyeron a la modernización de China.

Según los datos ofrecidos por el jesuita Bertram Wolferstan, en 1909, la situación de los católicos en China era la siguiente: $\mathrm{n}^{\circ}$ de misiones: $44 ; \mathrm{n}^{\circ}$ de obispos:13; $\mathrm{n}^{\mathrm{o}}$ de sacerdotes europeos: $1346 ; \mathrm{n}^{\circ}$ de sacerdotes chinos: 592; $\mathrm{n}^{\mathrm{o}}$ de religiosos europeos: $229 ; \mathrm{n}^{\circ}$ de religiosos chinos: $130 ; \mathrm{n}^{\circ}$ de religiosas europeas $558 ; \mathrm{n}^{\circ}$ de religiosas chinas: $1.328 ; \mathrm{n}^{\circ}$ total de católicos $1.071 .920 ; \mathrm{n}^{\circ}$ de catecúmenos $424.321^{4}$.

En 1948, a la vigilia de la Revolución Comunista, el número total de cristianos era de unos 5.000.000, correspondiendo a los católicos 3.251. 347 con 190.850 catecúmenos. Los católicos estaban divididos en 79 diócesis y 20 archidiócesis. En ellas trabajaban 5.588 sacerdotes seculares, de los cuales 2.542 eran chinos y 1.070 religiosos, de estos 663 eran chinos. El número de religiosas que desarrollaban diversas actividades apostólicas y caritativas era de 6.753, de las cuales 4.171 eran chinas. Los católicos atendían, por entonces 3 universidades, 202 escuelas secundarias, 184 escuelas primarias, 194 hospitales, 4 leprosarios, 257 orfanatos, 864 dispensarios y 29 imprentas 5 .

Pero, a pesar de los esfuerzos, el cristianismo será siempre una religión minoritaria. A principios del siglo XXI se calcula que el número de católicos es de unos doce millones y el de los protestantes unos 30 millones.

\section{b).- Los Agustinos en China}

Establecidos en Filipinas en 1565, los agustinos siempre tuvieron como meta llegar a China, para cuyo objetivo Filipinas era solamente un trampolín de lanzamiento.

Tras varios intentos frustrados, finalmente en 1575, los PP. Martín de Rada y Jerónimo Marín consiguieron llegar a China. Zarparon de Manila el 12 de junio de 1575. Viajaron por varias ciudades de la Provincia de Fujian, en las que fueron recibidos por las respectivas autoridades, quienes les agasajaron con banquetes y regalos. De paso, ellos aprovecharon para ir tomando información sobre los usos y costumbres del país, sobre la religión

\footnotetext{
${ }^{4}$ Wolferstan, Bertram, The Catholic Church in China, p. 453.

${ }^{5}$ Laurentin, René, Cina e cristianesimo, pp. 171-172.
} 
e historia, etc. No pudiendo llegar hasta el emperador, regresaron a Filipinas. Estaban ya de vuelta en Manila el 28 de octubre de $1575^{6}$.

Más tarde, en 1584, los agustinos fundaron el convento de Macao y, a partir de 1680, gracias a la labor de los PP. Álvaro de Benavente y Juan de Rivera comienzan las primeras fundaciones en las provincias de Guangdong y Guangxi, en el sur de China.

Las misiones crecieron grandemente hasta 1704 en que el papa publicó la bula "Ex illa die" sobre los ritos chinos lo que suscitó la persecución. Con grandes dificultades los agustinos permanecieron en estas regiones hasta 1818.

En 1877 son enviados a China los PP. Raymundo Lozano y Mariano Fábregas, para estudiar la posibilidad de establecer nuevas misiones en Hunan $^{7}$. Fruto de esta visita es la reanudación de las tareas misionales en 1879. Esta vez será a orillas del río Yangtze-kiang, en la provincia de Hunan, en el centro de China. Es encomendada a los agustinos una extensión de más de 81.000 kms. cuadrados con once millones de habitantes. Aquí desarrollaron una intensa labor apostólica y social hasta su expulsión en $1952^{8}$.

\section{(Ilustración 1)}

Dada la escasez de misioneros, era indispensable para la evangelización la colaboración de los catequistas. En la misión de los agustinos de Changteh estos eran, frecuentemente el marido y la mujer de una familia cristiana que vivía al pie de la iglesia o capilla de la misión y a expensas de esta. En 1923 eran 141 hombres y 114 mujeres?.

\footnotetext{
${ }^{6}$ Para estudiar la historia de este viaje véase: Rodríguez, Isacio, Historia de la Provincia Agustiniana del Santísimo Nombre de Jesús de Filipinas, Vol. XIV, Manila 1981; GoNZÁleZ de MENDOZA, Fr. Juan, Historia de las cosas más notables ritos y costumbres del Gran Reino de la China, Roma 1585. Una biografía del P. Rada puede encontrarse en: GALENDE, Pedro G. Apología pro Filipinos, Manila 1980; Boxer, C. R., South China in the Sixteenth Century, The Hakluyt Society, London 1953, pp. 243-310.

${ }^{7}$ LozAnO y Megia, Fr. Raymundo, Viage a China con algunas observaciones útiles y provechosas para los que vayan a aquel imperio, Manila 1979.

${ }^{8}$ Martínez, Bernardo, Historia de las misiones agustinianas en China, Imprenta del Asilo de Huérfanos del S. C. de Jesús, Madrid 1918; Sierra DE la CAlle, Blas, Pintura china de exportación, Museo Oriental. Valladolid, Catálogo III, Valladolid Caja España-Museo Oriental, Valladolid 2000, pp. 87-88; SIERRA DE LA CALle, Blas, Fr. Andrés de Urdaneta y los agustinos en China, en Diáspora. Anuario Misional, n 29, 2007-2008, pp. 35-38.

${ }^{9}$ Melcón, Agustín, Nuestras misiones en China en 1923, en Archivo Histórico Hispano Agustiniano, Vol. XXI, Enero-Junio 1924, p. 200.
} 
Según nos cuenta el P. Agustín Melcón, en 1923 estos catequistas eran "el elemento indispensable y más eficaz para el funcionamiento y progreso de la misión”. Pertenecientes al pueblo, y conviviendo con él atraen hacia la iglesia a los paganos, los hacen inscribirse entre los catecúmenos, les indican o proporcionan los libros de propaganda o doctrina cristiana más conveniente, les instruyen a ciertas horas en las verdades fundamentales de la fe; dirigen y acompañan sus rezos, representan al misionero en los centros de misión secundarios y, en ausencia del misionero sacerdote, son quienes hacen las veces y van al frente de todos los cristianos" ${ }^{\prime 10}$. (Ilustración 2)

En estos años fundaron y administraron 32 centros de misión, con casaresidencia e iglesia; 151 estaciones de misión con oratorio y casa para el misionero; 26 iglesias, 71 escuelas de niños y 57 de niñas; 2 colegios; un seminario; dos catecumenados y un orfanato, además de las casas de la misión de Shanghai y Hankow ${ }^{11}$.

Al salir de China los agustinos españoles en 1952, existían en su misión de Hunan 30.000 cristianos. Al frente de ellos quedaron una docena de agustinos chinos a quienes ha tocado afrontar difíciles tiempos de persecución y encarcelamiento, en especial durante la Revolución Cultural (19661976).

A partir de 1981 se ha iniciado una ligera apertura religiosa que se va incrementando en estos últimos años del siglo XXI.

\section{B.- LA IMPRENTA EN CHINA}

Una de las contribuciones más importantes de China a la civilización fue el invento del arte de imprimir, acontecimiento revolucionario que tuvo lugar en el siglo VIII.

\section{a.- Desarrollo de la imprenta en China}

Los orígenes de la imprenta se remontan a un pasado más lejano pues, anteriormente, ya existían múltiples técnicas de impresión sobre diversas superficies. Una de las técnicas de protoimpresión se basaba en el vaciado en bronce. Otro sistema para fabricar masivamente escrituras y textos sa-

\footnotetext{
${ }^{10}$ Melcón, Agustín, Nuestras misiones en China en 1923, p. 196.

${ }^{11}$ Estos datos se pueden ver en la revista: Casiciaco, Junio 1959, pp. 75 y ss.
} 
grados, consistía en estampar con tinta tallas de piedra de los escritos originales.

El primer texto que se imprimió en el mundo fue un rollo de hechizos budistas que se realizó en China entre los años 704 y 751. Y el primer libro impreso fue el "Sutra de Diamante" que se imprimió en el año 868.

Un oscuro estudiante llamado Pi Sheng -que vivió entre el 990 y el 1051-, inventó un tipo móvil realmente eficaz entre el 1041 y 1048. Dos siglos y medio después Wang Chen perfeccionó el tipo de madera, con el que imprimiría en 1313 su obra clásica "Tratado de Agricultura"12.

Durante la dinastía Ming (1368-1644) las principales imprentas se encontraban en las capitales de Pekín y Nanking, así como en Hangzhou, Huizhou y Jianyang. A finales de la dinastía Ming y principios de la dinastía Qing (1644-1912) las elites literarias se trasladaron a Suzhou, Hangzhou, Nanking y Yangzhou.

A finales del siglo XVIII y principios del XIX, surge en Pekín el distrito de libreros de Liulichang, donde se concentrarían la mayor parte de la industria de impresión de libros. El embajador inglés Sir Rutherford Alcock -que pasó por Liulichang en 1870-, confirma la existencia de numerosas imprentas concentradas en este distrito ${ }^{13}$.

En las primeras décadas del siglo XX, Shanghai pasó a ser el principal centro de impresión de libros, marginando tanto a Pekín como a otros centros de publicaciones. Esta industria estaba concentrada en el distrito conocido como Wenhuajie (Calles de cultura y educación) que se encontraba dentro de la zona de la Concesión Internacional Anglo-Americana. Allí se concentraban también libreros, impresores, calígrafos, pintores, escritores,

12 Amplia información sobre la historia de la imprenta puede verse en: CARTER, Th. Francis, The Invention of Printing in China and its Spread Westward, Columbia University Press, New York, 1925; Pelliot, Paul; Le débuts de L'imprimerie en Chine, Imprimerie Nationale, Paris 1953; Guouun, Liu-Rusi, Zheng, L'histoire du livre en Chine, Editions en Langues étrangéres, Beijing 1989: Wou, Tchen-fou, Chine. L'estampe, Editions Philippe Picquier, Paris 1990; NeEdHAM, Joseph, Science and Civilisation en China. Vol. 5 Chemistry and Chemical Technology, Part I: Paper and Printing, by Tsien Tsuen-hsuin, Cambridge University Press, Cambridge, 1985; BARRET, T. H., The Woman who discovered printing, Yale University Press, New Haven and London 2008; Shubao, Luo,(Edit.)An Illustrated History of Printing in Ancient China, City University of Hong Kong Press, Hong Kong 1998; SiERRA DE La CAlle Blas, Museo Oriental. China, Japón, Filipinas. Obras selectas. Edición Caja España, Museo Oriental, Valladolid 2004, pp. 234-235.

${ }^{13}$ REED, Christopher, Gutenberg in Shanghai, pp. 10-11. 
anticuarios y tiendas especializadas en los cuatro tesoros del estudio del letrado los "Wefang Sibao" (tinta china, tinteros, pinceles y papel). Se llegaron a juntar alrededor de 300 firmas distintas de impresores, publicistas y libreros. Las tres principales imprentas en Shanghai de este periodo fueron: Comercial Press, Zhonghua Books y World Books, situadas todas ellas en el distrito de Wenhuajie ${ }^{14}$.

En todas estas imprentas el método xilográfico fue sustituido por las técnicas mecánicas de impresión. Además de novelas, se imprimieron obras de ciencias sociales, libros de referencia clásicos, así como periódicos y re$\operatorname{vistas}^{15}$.

\section{b).- La impresión de grabados policromados}

La impresión de grabados de imágenes en China es muy anterior a la aparición de la imprenta. Durante la dinastía Han (206-a. C. -220 d. C.) los chinos ya realizaban grabados utilizando bloques de piedra y en otros casos ladrillos.

Las estampas a partir de bloques de madera comenzaron a realizarse entre el 680 y 750, durante la dinastía Tang. El desarrollo de esta nueva técnica de impresión estuvo, durante mucho tiempo, estrechamente relacionada con la religión budista y contribuyó a su difusión en China. Los temas religiosos de los grabados serán los que predominarán en un principio.

Con la dinastía Yuan (1279-1368) y más tarde, durante las dinastías Ming y Qing irán abriéndose camino los grabados de temas literarios y científicos, así como las escenas de la vida de la naturaleza.

La impresión multicolor, a partir de varios bloques de madera fue introducida en el siglo XII. Se tallaban bloques separados para cada color, y algunas de las gradaciones de color eran conseguidas pintando tintas más diluidas o concentradas en el mismo bloque. Esta técnica requería impresores expertos, mucho más especializados que los impresores a tinta china negra.

Las principales innovaciones técnicas en este campo de la impresión policromada se atribuyen a dos autores de la dinastía Ming (1368-1644). Uno de ellos es Min Qiji , autor de la obra "Las diez vistas del Monte Wu" y el otro Hu Zhengyan ${ }^{16}$.

\footnotetext{
${ }^{14}$ REED, Christopher, Gutenberg in Shanghai, p. 17.

${ }^{15}$ REED, Christopher, Gutenberg in Shanghai, p. 11.

${ }^{16}$ Cohen, Monique-Monnet, Nathalie, Impresions de Chine, Biblioteque Nationale, Paris 1992, pp. 147-156.
} 
Este método fue usado para producir hermosos álbumes basados en pinturas, que eran usados frecuentemente como manuales de pintura. Más tarde en el siglo XIX y principios del siglo XX fueron utilizados comúnmente para producir las conocidas pinturas de Año Nuevo en largas hojas impresas en media docena de colores, siguiendo el gusto popular, muy alejado de las pinturas refinadas de los manuales. En estos grabados del Año Nuevo se utilizaban símbolos que eran tradicionalmente considerados de buen auspicio. Además de los populares "Dioses Porteros" había otros alusivos a los motivos de la juventud, la larga vida, la carrera oficial en el gobierno, o la riqueza. Los niños estaban también relacionados con todos estos deseos ${ }^{17}$.

\section{c).- La propaganda anticristiana}

A finales de la dinastía Qing (1850-1911) las misiones cristianas eran percibidas por los chinos, generalmente, como un brazo cultural del imperialismo occidental y como una amenaza al orden tradicional chino y a su identidad cultural.

Los sentimientos anticristianos eran especialmente fuertes entre los letrados chinos, intelectuales confucianos y la alta sociedad local. Todos ellos consideraban al cristianismo no solo como una religión extranjera, sino como una secta heterodoxa, especialmente después de que el cristianismo hubiese sido prohibido - tras la controversia de los ritos chinos-, por varios edictos de los emperadores Kangxi y Yongzheng. Estos sentimientos anticristianos y antiextranjeros llevaron a centenares de actos violentos y de persecución contra los cristianos ${ }^{18}$.

La oposición al cristianismo fue instigada por escritos literarios anticristianos, así como por medio de panfletos y posters. Uno de estos panfle-

${ }^{17}$ Wood, Frances, Chinese Ilustration, The British Library Board, London 1985, p. 83; Comentale Christophe, Les estampes chinoises. Invention d'une image, Editions Alternatives, Paris 2003, p. 97-123; SierRA DE LA CALle, Blas, Imágenes de la Revolución Cultural China, Museo Oriental. Valladolid. Catálogo V, Edición Caja España-Museo Oriental, Valladolid 2001, pp. 89-90.

${ }^{18}$ Cohen, Paul, A., China and Christianity. The Missionary Movement and the Growth of anti-foreignism 1860-1870, Harvard University Press, Cambridge 1963; CoHEN, Paul, A., Christian Missions and their Impact to 1900, en: FAIRBANK, John, K., (Edit) The Cambridge History of China, Volume 10, Late Ch'ing, 1800-1911, Part I, Cambridge University Press, Cambridge 1978, p. 569; LAI, John T. P., Literary Representations of Christianity in late Qing and republican China, Brill, Leiden-Boston 2019, pp. 110-111. 
tos que tuvo una gran repercusión fue el titulado "Gui Jiao Gai Si” (Maldito Culto del demonio). Su autor, Zhou Han (1842-1911) era un miembro del ejército de la provincia de Hunan, que tuvo un papel predominante en la supresión de la Rebelión Taiping. Esta obra -de la que se pusieron en circulación unos 800.000 ejemplares-, tuvo un gran impacto y fue ampliamente distribuida en las provincias centrales de China e, incluso, a través de los miembros de las triadas ${ }^{19}$.

De modo similar, en posters y otras publicaciones la figura de Jesús era representada gráficamente como un cerdo. Esto se basaba en el hecho que el ideograma chino por "Señor" $(Z h u)$ se pronuncia de la misma manera que cerdo (Zhu), aunque se escriba de forma distinta. Así aparece en una obra muy difundida a finales del siglo XIX, titulada "La causa de los tumultos en el Valle del Yangtse"20. Se publicó en contra de los extranjeros y de los misioneros cristianos. A unos y a otros se les acusa de todas las monstruosidades posibles (desde el infanticidio, hasta el abuso de las mujeres chinas) al mismo tiempo que se les trata de ridiculizar a ellos y a sus creencias representándoles en forma de ciervos cornudos o cerdos. (Ilustración 3)

Al mismo tiempo, los misioneros occidentales eran acusados frecuentemente de predicar la promiscuidad sexual, porque se permitía en las reuniones litúrgicas que estuvieran mezclados los hombres y las mujeres. Teniendo esto en cuenta, la imagen del cerdo -que en la cultura china está vinculada al sexo y a la fertilidad-, servía para presentar de modo negativo tanto a la fe cristiana como a sus representantes, los misioneros ${ }^{21}$.

\section{d).- Las imprentas católicas en el siglo XX}

A finales del siglo XIX y principios del siglo XX la imprenta se convirtió en uno de los principales agentes de propaganda en todo el mundo. Contemporáneamente la palabra impresa adquirió una gran importancia como medio de difusión del mensaje cristiano.

A principios del siglo XX, los católicos en China tenían cinco imprentas principales: la de los Lazaristas en Pekín, la de los Jesuitas en Shanghai,

\footnotetext{
${ }^{19}$ LAI, John T. P., Literary Representations of Christianity in late Qing, p. 111; COHEN, Paul, A., Christian Missions and their Impact to 1900, p. 570.

${ }^{20}$ The cause of the Riots in the Yangtse Valley. A complete Picture Gallery, Hankow 1891.

${ }^{21}$ LAI, John T. P., Literary Representations of Christianity in late Qing, p. 112.
} 
la de las Misiones Extranjeras en Hong Kong, la de los Salesianos en Macao y la de la Sociedad de la Divina Palabra, también en Pekín.

Además de estas, sabemos de la existencia de otras varias: 2 en Manchuria, 2 en Shanshi, 2 en Kiangsu; 2 en Szechwan, 3 en Hopei, 3 en Hupei, 3 en Kuangtung, 1 en Hunan, 1 en Chekiang, y 1 en Fukien ${ }^{22}$.

La imprenta de los Lazaristas comienza a funcionar en Pekín en 1862, bajo el nombre de "Imprimerie Lazariste”. Se convirtió en una de las imprentas católicas más importantes de China en el siglo XX. De ella salieron entre 1864 y 1930, más de 500 obras en chino, mongol, tibetano, francés, latín, inglés, alemán, holandés, italiano y español. Los temas de estas publicaciones eran gramáticas, libros de oración, devocionarios, obras de teología,...23

En la imprenta de los jesuitas de Zi-Ka-Wei, en Shanghai, comenzaron con la impresión con bloques de madera en 1874, pero, posteriormente, añadieron los tipos mecánicos, lo que les permitió producir libros más baratos y en mayor cantidad. Se publicaron numerosos estudios para la Universidad Aurora, para la Escuela de Altos Estudios Industriales y Comerciales, fundada en 1923, así como para el Observatorio de los jesuitas. La obra más prestigiosa sería la serie "Varietés Sinologiques" que en 1936 había publicado ya 36 volúmenes, llegando más tarde a 66 volúmenes ${ }^{24}$.

En el año 1937 en esta imprenta de los jesuitas trabajaban 120 personas, gran parte de ellos residentes del orfanato de T'ou-Se-We, en Zi-KaWei. Producían al año 75.000 ejemplares de obras en lenguas europeas y 350.000 ejemplares de libros en lengua china. Además de libros con texto e ilustraciones artísticas, imprimían también calendarios, tarjetas de visita, recordatorios de ordenaciones o primeras comuniones, etc. ${ }^{25}$. (Ilustración 4)

Por su parte la imprenta de las Misiones Extranjeras en Hong Kong tenían en plena producción tres rotativas que siguieron imprimiendo obras de temática cristiana hasta el triunfo de la revolución comunista en $1950^{26}$.

${ }^{22}$ CAry-Elwes, Columba, China and the Cross., p. 208.

${ }^{23}$ RyBolt, John, E., The Vicentians. A General History of the Congregation of the Mission. Expansions and reactions (1843-1878), New City Press, New York 2014, Nota 2602.

${ }^{24}$ CARY-Elwes, Columba, China an the Cross., p. 208. Más información sobre esta imprenta de los jesuitas en Zikawei puede verse en: Mugello, D. E., The Catholic Invasión of China. Remaking Chinese Christianity, Rowman \& Littlefield, New York-London, 2015, pp. 24-25.

${ }^{25}$ Henriot, Christian-Macaux, Ivan, Shanghai: Scènes de la vie en Chine. Les figurines de bois de T'ou-Sè-Wè, Editions des Equateurs, Paris, 2014, p. 44.

${ }^{26}$ CARY-Elwes, Columba, China an the Cross., p. 209. 


\section{e).- Las imprentas protestantes en el siglo $\mathrm{XX}$}

Las obras impresas han sido siempre un instrumento fundamental utilizado por los protestantes como medio de evangelización. La distribución de la Biblia o partes de la misma, fue uno de los métodos más comunes utilizados por los protestantes para acercar el mensaje cristiano a la población china.

En un principio estas Biblias eran impresas en Inglaterra y otros países occidentales pero, ya a partir de 1895 , tenemos constancia de la existencia en China de una decena de imprentas protestantes. El historiador K. S. Latourette ofrece la siguiente lista: 1.- The American Presbiterian Missión; 2.- The American Board of the Church Missionary Society; 3.- The English Presbiterians; 4.- The National Bible Society of Scotland; 5.-The Society for the Difussión of the Christian and General Knoweledge; 6.- The Methodist Episcopalian Mission at Foochow; 7.- The Central China Press; 8.The China Indian Mission Press ${ }^{27}$. A estos habría que añadir la imprenta de la London Missionary Society que a lo largo del siglo XIX difundió numerosas publicaciones entre los chinos ${ }^{28}$.

En 1914 el número de imprentas protestantes había aumentado hasta diecinueve. La mayoría de los libros que se imprimían eran Biblias completas, o partes de la misma. El número de ejemplares que se distribuían gratuitamente o a un precio simbólico era ingente. Se tiene constancia que, en 1924 se distribuyeron más de nueve millones de biblias ${ }^{29}$.

\section{f.- La imprenta de los agustinos en China en el siglo XX}

Changteh era en el primer cuarto del siglo XX una ciudad de unos 300.000 habitantes. Los agustinos consiguieron establecerse en 1899. El primer misionero agustino que residió allí fue el P. Abrahán Martínez. En este lugar se edificaron entre 1916-1917 una espaciosa casa, con apariencia de convento, y su iglesia correspondiente.

En el año 1921 se construyó un nuevo edificio para la imprenta. En ella se imprimieron obras tanto con caracteres chinos, como europeos.

${ }^{27}$ Latourette, Kenneth Scout, A History of Christian Missions in China, p. 437. Más información en pp. 438-441.

${ }^{28}$ Ching Su, K., The Printing Presses of the London Missionary Society, University College, London 1996.

${ }^{29}$ Información más detallada sobre esta millonaria distribución de ejemplares puede verse en: Wolferstan, Bertram, The Catholic Church in China, pp. 55-67. 
Según los datos que ofrece la obra publicada en 1929, con motivo del 50 Aniversario del Vicariato, en esta imprenta "hasta el año 1927 se habían impreso más de 200.000 ejemplares de libros de doctrinas, propaganda, relaciones..." ${ }^{30}$. (Ilustración 5)

En la Exposición Vaticana de Misiones, celebrada en Roma en 1925, los agustinos estuvieron presentes con una importante colección de obras de arte y etnología, tanto de China como de la Amazonía Peruana. Al mismo tiempo, presentaron en dicha muestra 500 libros de carácter religioso, científico e histórico, sobre China, Filipinas, Amazonía, temas agustinianos, la mayor parte de ellos escritos por autores agustinos ${ }^{31}$.

Los libros editados en chino fueron enviados por el P. Vicente Avedillo desde Changteh ${ }^{32}$. Se encontraban entre ellos algunas obras del P. Tomás Ortiz, como la "Explicación de los novísimos en lengua china" publicada en Chungchin, Stechuan, en 1836, y la "Explicación de la doctrina cristiana en lengua china" procedente, precisamente, de la Imprenta Agustiniana de Changteh ${ }^{33}$.

Otra obra publicada en la Imprenta Agustiniana de Changteh, que estuvo presente en la Exposición Vaticana fue la "Memoria-Relación del Vicariato de Hunan Septentrional (China) encomendado a los PP. Agustinos españoles de la Provincia del Santísimo Nombre de Jesús de Filipinas”. Año 1923-1924"34.

En esta relación sobre el estado de la misión de Changteh en 1923, el P. Agustín Melcón deja constancia que "contamos con el modesto establecimiento tipográfico de Changteh, destinado principalmente a la difusión de los libros de catequesis en chino, pero que se sentiría orgulloso contribuyendo a que las obras y adelantos de los misioneros fueran algo más conocidos, de lo que han sido hasta ahora" 35 .

${ }^{30}$ AA. VV., Vicariato de Changteh, 1879-1929, Hunan, China, PP. Agustinos Españoles, Dah Hsing Printing Office, Hankow, 1929.

${ }^{31}$ Díez Aguado, Manuel, Los PP. Agustinos en la Exposición Vaticana de las Misiones, Imprenta del Real Monasterio del Escorial, El Escorial 1926, pp. 67-116.

${ }^{32}$ Díez Aguado, Manuel, Los PP. Agustinos en la Exposición Vaticana, p. 66.

${ }^{33}$ Díez Aguado, Manuel, Los PP. Agustinos en la Exposición Vaticana, p. 101.

${ }^{34}$ AA. VV., "Memoria-Relación del Vicariato de Hunan Septentrional (China) encomendado a los PP. Agustinos españoles de la Provincia del Santísimo Nombre de Jesús de Filipinas”. Año 1923-1924” Imprenta del Sagrado Corazón, Changteh, Hunan 1924. Citado en: Díez Aguado, Manuel, Los PP. Agustinos en la Exposición Vaticana, p. 96.

${ }^{35}$ Melcón, Agustín, Nuestras misiones en China en 1923, p. 196. 


\section{C.- LIBROS ILUSTRADOS PARA LA CATEQUESIS EN CHINA}

La letra escrita, el libro, es esencial para transmitir ideas, mensajes y como medio de adoctrinamiento, tanto en el mundo religioso como en el político. Pero, hay que tener en cuenta que para acceder a ellos se necesita que la población sea capaz de entenderlos, es decir, sea capaz de leer. A finales de la dinastía Qing, en 1912, se calcula que la población china era de unos 450 millones de personas. Según el investigador Christopher A. Reed, por entonces el número de chinos que sabía leer era entre el 20 y el $25 \%$ de la población, es decir entre 90 y 110 millones de habitantes. Estas personas vivían, fundamentalmente, en las zonas urbanas ${ }^{36}$.

Desde que Mao Zedong (Mao Tse Tung) declarara la República Popular el 1 de octubre de 1949, China se ha convertido en una de las culturas del libro más destacadas. El Partido Comunista ha promovido la producción de libros a gran escala. Un ejemplo de ello es que del famoso "Libro rojo de Mao" se llegaron a imprimir cerca de un billón de copias y unos 150 millones de copias de sus "Obras selectas" 37.

\section{a).- La importancia de la imagen}

El lenguaje escrito puede ser comprendido por aquellas personas que saben leer y escribir una determinada lengua. Para quienes no conocen el idioma, esas palabras escritas carecen de significado y no transmiten nada. Sin embargo la imagen tiene un carácter más universal y, a través de ella, se puede transmitir un mensaje a todas las personas, independientemente que estas sepan o no leer y escribir.

Esto lo saben muy bien lo políticos y lo sabían muy bien Mao Zedong y los comunistas chinos, al igual que sus colegas los rusos y otros movimientos revolucionarios de distintos signos. De ahí que hayan desarrollado una ingente tarea de propaganda a base de carteles para adoctrinar a las masas, de los que se imprimieron muchos millones de copias presentando a las masas iletradas "el paraíso comunista"38.

\footnotetext{
${ }^{36}$ REED, Christopher, Gutenberg in Shanghai, p. 5.

${ }^{37}$ REED, Christopher, Gutenberg in Shanghai, p. 22.

${ }^{38}$ Amplia información sobre el tema, en: SiERRA DE LA CALLE, Blas, Imágenes de la Revolución Cultural China, en especial pp. 81-106.
} 
La historia de la difusión del cristianismo ha tenido esto muy en cuenta desde un principio. Durante siglos la gran masa de la población iletrada, era instruida y catequizada por medio de imágenes esculpidas, pintadas o grabadas que hacían que las verdades de fe -además de por el oído, escuchando la catequesis del predicador-, entrasen también por los ojos.

Los misioneros que, a lo largo de los siglos evangelizaron América, Asia y África han tenido esto también en cuenta promoviendo los catecismos pictográficos y las obras de arte de imágenes sagradas.

Las imágenes han sido particularmente importantes a la hora de difundir el mensaje cristiano en China. Entre los motivos para esta afirmación está, por un lado, la dificultad a la que tenían que enfrentarse los misioneros occidentales a la hora de aprender la lengua china y sus complicados ideogramas. Se necesitaban varios años de estudio y práctica hasta que podían hacerse entender correctamente por los de su feligresía.

A esto hay que añadir la situación sociológica de las comunidades cristianas chinas. Salvo algunas excepciones la gran mayoría de los cristianos -tanto católicos como protestantes-, provenían del mundo rural, con escasa formación intelectual. Según los datos que proporciona el "China Year Book de 1923" solamente el 2\% del total de la población china estaba escolarizada y, por lo tanto, era capaz de leer y escribir. Entre los cristianos -dada la tarea educativa desarrollada por los misioneros-, el porcentaje de personas escolarizadas se elevaba al 14\%. En cualquier caso, en ambos grupos está claro que el número de personas letradas capaces de leer y escribir era minoritario ${ }^{39}$.

El libre uso de pinturas en la enseñanza de los jóvenes se convirtió ya a principios del siglo XX en algo común en el sistema educativo de todos los países civilizados. Ha sido incluso universalmente adaptado para la alfabetización de los niños. Así para enseñar a leer cada letra del alfabeto se ha asociado con un objeto familiar que inicia con esa letra. Igualmente en China, para enseñar los ideogramas se utilizaban imágenes de modo que era fácil memorizar el ideograma asociado. En el Museo Oriental del Real Colegio de PP. Agustinos de Valladolid se expone una caja de ideogramas chinos impresos en xilografía que se utilizaban para enseñar a leer y escribir. Al lado de cada figura (casa, pato, granada, reloj, gusano de seda,...) se representa el dibujo correspondiente.

\footnotetext{
${ }^{39}$ Latourette, Kenneth Scout, A History of Christian Missions in China, p. 731.
} 
Para la enseñanza de la doctrina cristiana, todos los creyentes podrán admitir con facilidad que el ofrecer estas pinturas y grabados religiosos a los niños excitaba en ellos un mayor interés por las cosas sagradas y, al mismo tiempo, estimulaba los sentimientos religiosos en ellos.

\section{b).- Los modelos iconográficos}

Conocemos la existencia de algunas obras de arte europeo, así como de libros impresos que llegaron a China y tuvieron un influjo en la representación de las verdades cristianas.

\section{Grabados europeos}

Grabados europeos con representaciones del Antiguo y Nuevo Testamento llegaron a China como ilustraciones de ejemplares de la Biblia, o de otras publicaciones de carácter religioso. Tenemos constancia del influjo que tuvo en la decoración de las porcelanas chinas la Biblia luterana "Nederduytse Bijbel” ilustrada por Jan Luyken (1649-1712), publicada en Ámsterdam en $1750^{40}$. Jan Luyken ilustró muchas ediciones de la Biblia y otras publicaciones religiosas, que incluían series de 24 grabados de escenas del Nuevo Testamento. Publicadas en 1680 se hicieron muy populares, tanto en Europa como en otros países ${ }^{41}$. Del mismo modo que fueron utilizadas para la decoración en porcelanas, igualmente fueron fuente de inspiración para la ilustración de publicaciones religiosas.

Además de los libros, los misioneros católicos y protestantes llevaron a China también estampas de la vida de Cristo, de la Virgen y de los santos, tanto para su devoción personal, como para repartir entre los recién convertidos.

Aunque todavía no se ha estudiado con detalle este tema, tenemos algunos testimonios que nos ofrecen pistas de información, entre ellos el informe del agustino P. Martín de Rada sobre su viaje a China en 1575. Él nos cuenta que mientras estaban en Hocchin (Provincia de Fujian) el virrey o mandarín de la ciudad pidió "que le enviásemos el libro con que solíamos rezar, que lo quería ver, y como le enviásemos el Breviario tomó de él cinco o seis estampas de unas questavan por registros, entre las cuales tomó

\footnotetext{
${ }^{40}$ Nederduytse Bijbel ilustrada por Jan Luyken (1649-1712), Ámsterdam 1750.

${ }^{41}$ WelshH, Jorge ( Edit.) Christian images in Chinese Porcelain, London 2003, p. 48.
} 
un crucifijo y una columna y un ecce homo y una coronación de nuestra señora y una imagen de sancta Brígida, y no sé si alguna otra más,..." ${ }^{42}$.

También llegaron a China grabados de las pinturas religiosas de varios grandes artistas europeos, bien italianos, españoles, alemanes o flamencos. Como se verá a continuación, algunas pinturas de Rafael Sanzio, Leonardo da Vinci y de Bartolomé Estaban Murillo, entre otros, sirvieron de fuente de inspiración para ilustrar libros religiosos y catecismos.

\section{La Biblia de Nadal}

Se conoce como "Biblia de Nadal” la obra "Evangelicae Historiae Imágines" ("Imágenes de Historia Evangélica”), escrita por el jesuita P. Jerónimo Nadal y publicada en Amberes en $1593^{43}$.

El texto del P. Nadal sobre la vida de Jesucristo se completaría con los diseños dibujados por los artistas, Livio Agresti, P. Johan Zonhoeven, Bernardino Passari, Martin de Vos. Estas imágenes fueron trasladadas a grabados por los célebres grabadores flamencos Antón Wierix (1555/59-1604) que grabó 58 imágenes; Hieronymus Wierix (ca. 1553-1619) que grabó 56 imágenes; Jan Wierix (1549-1618) que grabó 17 imágenes; Adrian Collaert (1560-1618) que grabó 11 imágenes; Jan Collaert (1540-1620) que hizo una, Carlos van Mallery (1516-1631) que realizó 9, y el resto anónimas hasta un total de 153 grabados $^{44}$.

Ejemplares de esta obra fueron llevados a China por los jesuitas en 1605. El P. Mateo Ricci, a propósito de la misma, escribía el 12 de mayo de 1605: "este libro es tan necesario en aquella cristiandad,... más útil por el momento que la misma Biblia, porque ayuda para declarar y aun para poner ante los ojos lo que con palabras no podemos expresar" $" 4$.

La obra del P. Nadal serviría de inspiración para otras publicaciones con imágenes promovidas en China por otros jesuitas. Así el P. Joao da Rocha (1565-1623) portugués que llegó a China en 1598, publicó el “Método

${ }^{42}$ Rodríguez, Isacio, Historia de la Provincia Agustiniana, Vol. XIV, p. 284; SIERRA DE LA CAlle, Blas, La evangelización de Filipinas durante el gobierno de Legazpi (1565-1572), en: Cabrero, Leoncio ( Edit), España y el Pacífico. Legazpi. Tomo I, Sociedad Estatal de Conmemoraciones Culturales, Madrid 2004, p. 363.

${ }^{43}$ NADAL, Jerónimo, Evangelicae historiae imagines, Amberes 1593.

${ }^{44}$ García GutiÉRreZ, Fernando, Los grabadores flamencos de los siglos XVI y XVII y la Compañía de Jesús, Real Maestranza de Caballería de Sevilla, Sevilla 2002, pp. 155-156.

${ }^{45}$ Citado en: García Gutiérrez, Fernando, Los grabadores flamencos de los siglos XVI y XVII , p. 162. 
del Rosario". Esta obra lleva 14 ilustraciones de los misterios del Rosario, inspiradas en el libro de $\mathrm{Nadal}^{46}$. El P. Julio Aleni (1582-1649) italiano de Brescia y misionero en China desde 1610, publicó en 1635 su obra "Evangelios expuestos por medio de la imagen" que contenía unos 49 grabados realizados por un artista chino, siguiendo los modelos de Nadal. Por su parte el P. Juan Adam Schall von Bell (1591-1669) natural de Colonia y misionero en China desde 1622, compuso una "Vida de Cristo" que iba acompañada de 48 grabados, algunos de los cuales seguían los modelos de las láminas de $\mathrm{Nadal}^{47}$.

El éxito que la obra del P. Nadal tuvo en China fue enorme. De ahí que fuese altamente estimada por los misioneros como medio de catequización. Así nos lo demuestra el testimonio del P. Francisco de Rougemont quien escribe en 1658: "La práctica nos ha enseñado muchas cosas (...) Hemos venido cargados con muchos libros cuando hubieran bastado las imágenes, tanto en pergamino como en papel, acerca de los misterios de la fe. Lo que sobre todo aquí se estima es la Vida de Cristo editada por el P. Jerónimo Nadal y grabada por Jerónimo Wierix; y es un regalo en verdad utilísimo" $"$.

En los siglos siguientes las “Imágenes de Historia Evangélica”, del jesuita P. Jerónimo Nadal con las ilustraciones de los grabadores flamencos, seguiría influyendo en muchas de las publicaciones sobre doctrina cristiana que se realizaron en China.

\section{Láminas del Antiguo y Nuevo Testamento de Julius Schnorr von Ca- rolsfeld}

Otra de las obras de las que tenemos constancia que inspiraron las representaciones de la doctrina cristiana en diversas publicaciones de China es la "Gran Colección de láminas del Antiguo y Nuevo Testamento de Julius Schnorr von Carolsfeld" 4 .

${ }^{46}$ Reed Marcia-Demattè, Paola (Edit.) China on Paper. European and Chinese Works from the Late Sixteenth to the Early Nineteenth Century, Getty Research Institute, Los Angeles 2007, pp. 32-33, 168-171.

${ }^{47}$ GarCía GutiérReZ, Fernando, Los grabadores flamencos de los siglos XVI y XVII, p. 163.

${ }^{48}$ Citado en: García Gutiérrez, Fernando, Los grabadores flamencos de los siglos XVI y XVII, p. 163.

${ }^{49}$ Schnorr von Carolsfeld, Julius, Gran colección de láminas del Antiguo y Nuevo Testamento, Imprenta y Litografía de Faustino Paluzié, Barcelona 1885. 
Julius Schnorr von Carolsfeld (1794-1872) fue un pintor grabador alemán asociado al movimiento de los Nazarenos. Su carrera artística se suele dividir en tres periodos. El primer periodo corresponde a su etapa romana de 1815 a 1825, dentro del grupo de los Nazarenos, donde se familiarizó con las pinturas al fresco y realizo varias obras importantes, entre ellas la decoración de la "Villa Mássimo" cerca de la Basílica del Laterano. El segundo periodo va de 1825 a 1846 y, por entonces, trabajó en Munich al servicio de Ludwig I de Baviera, ilustrando su palacio con la historia de los Nibelungos. El tercer periodo de su vida se desarrolló en Dresden donde, además de profesor de la Academia de Bellas Artes, fue Director de la Gemalde Galerie.

Entre 1852 y 1860 trabajó en la ilustración de historias bíblicas del Antiguo y Nuevo Testamento. Creó 240 láminas que serían publicadas en esos años en Leipzig. En el año 1861 se realizó la edición inglesa y en 1885, Faustino Paluzié realizaría la edición española en Barcelona.

Estas ilustraciones de la Biblia marcaron la devoción bíblica en Alemania durante muchas generaciones. Se publicaron y reeditaron en diversos países europeos hasta 1940. Junto a Gustave Doré, el artista Julius Schnorr von Carolsfeld es considerado el ilustrador más importante de la Biblia del siglo XIX.

En sus últimos años realizó las vidrieras para las catedrales de Glasgow y San Pablo de Londres ${ }^{50}$.

\section{La Historia Sagrada del Antiguo y Nuevo Testamento de Ignaz Schuster}

Ignaz Schuster (1813-1869) fue un sacerdote alemán, especialista en catequesis, nacido en Ellwangen. Ordenado sacerdote en 1837 ejerció el ministerio pastoral en Treffelhausen a partir de 1841. En 1847 obtendría el doctorado en Teología en la Universidad de Friburgo y, desde 1857 hasta su muerte ejercería su ministerio en Unterailingen. Destacó por sus estudios sobre catequesis. Entre ellos cabe citar: Catecismo de la Religión Católica, Manual de Catequesis, en cinco volúmenes y la Historia Bíblica del Antiguo y Nuevo Testamento ${ }^{51}$.

${ }^{50}$ WAEtzoldt, Stephan, German Masters of the Nineteeth Century, Metropolitan Museum of Art, New York 1981, pp. 272-273.

${ }^{51}$ SCHUSTER, Ignaz, Katechismus der katholichen Religion, Freiburg im Breisgau 1845; Katechetisches Handbuch, 5 Bande, Freiburg 1846-1854; Biblische Geschichte des Alten Testaments un Neuen Testament, Freiburg 1847; http://www.kathpedia.com/index.php/Ignaz_Schuster 
Su obra Historia Sagrada del Antiguo y Nuevo Testamento - publicada originalmente en alemán en 1847-, sería muy pronto traducida a distintos idiomas, obteniendo una gran difusión. Entre 1888 y 1906 varios obispos de lengua española -entre ellos los de Madrid Alcalá, Chiapas, México, Quito, Bogotá, Granada, Buenos Aires, Tunja,...-, promovieron su publicación en lengua castellana. Esta edición verá la luz en Friburgo de Brisgovia, Alemania en $1908^{52}$.

El texto sobre las distintas historias bíblicas está acompañado por 114 grabados en blanco y negro y dos mapas. La mayor parte de los diseños son anónimos, aunque hay una pequeña parte que llevan la firma del grabador. En nueve de ellos puede leerse la firma H.M.; en dos el nombre Henri Weber K. A. Stuttgart; uno lleva las iniciales C.H.; y otro más la firma L. Fraule.

Como veremos más adelante, varios de estos grabados están inspirados en los grabados de pintores europeos, la Biblia de Nadal, y las láminas del Antiguo y Nuevo Testamento de Julius Schnorr von Carolsfeld.

\section{La obra francesa "Catecismo en Imágenes"}

Otra de las obras de las que tenemos constancia que influyó en las representaciones de imágenes cristianas en China es el "Catecismo en Imágenes" publicado originalmente en francés por la "Maison de la Bonne Presse" de París. Estaba dividido en cuatro partes, según el orden del catecismo del Concilio de Trento: 1.- El credo de los apóstoles; 2.- Los sacramentos; 3.- Los mandamientos de Dios y de la Iglesia: 4.- Oraciones, novísimos, pecado y virtud, obras de misericordia.

El "Grand Catechisme en Images" contenía 68 cromolitografías. De esta edición en color se publicaron más de 20.000 ejemplares. Para reducir los costes se realizó en 1909 una edición con las litografías en blanco y negro. Solo en los primeros tres años se habían vendido 200.000 copias. Dado el gran éxito obtenido se decidió realizar ediciones en otras lenguas entre ellas: español, portugués, polaco, japonés, chino, tamil, cingalés, italiano, flamenco y alemán ${ }^{53}$.

${ }^{52}$ SCHuster, Ignaz, Historia Sagrada del Antiguo y Nuevo Testamento, B. Herder librero y editor, Friburgo de Brisgovia 1908. Aparecerá también una edición en lengua visaya, promovida por el obispo filipino de la diócesis de Jaro, Dionisio Dougherty: SCHUSTER, Ignaz, Historia Sagrada sang daan cag bag-o nga Testamento, Tipografía pontificia de B. Herder, Friburgo de Brisgovia 1915.

${ }^{53}$ Maison de la Bonne Presse, Catecismo en estampas. 70 grabados en negro, Casa de la Buena Prensa, Paris 1909. Imágenes de esta obra, así como de otros muchos autores apa- 
Un misionero jesuita, escribiendo desde China, deja constancia de que esta obra era usada allí en la catequesis. Él comenta: "Las pinturas del catecismo recibidas de "La Bonne Presse" han sido mostradas aquí en nuestra capilla y han sido comprendidas por todos aquellos que las han contemplado. Este método de explicar el Antiguo y Nuevo Testamento es tan bueno como una serie de los más elocuentes sermones" ${ }^{4}$.

Estas imágenes también fueron fuente de inspiración -como veremos más adelante-, para los ilustradores chinos que trabajaron en la ilustración de obras de catequesis cristiana.

\section{SEGUNDA PARTE: DESCRIPCIÓN DE TRES OBRAS GRÁFICAS CHINAS}

En esta segunda parte se estudian las imágenes que aparecen en tres obras gráficas chinas de la primera mitad del siglo XX: "La Historia Sagrada" de 1929, el "Catecismo chino en láminas policromadas" de 1925 y "La Historia más famosa”, una vida de Jesús, de 1950.

\section{A.- LA HISTORIA SAGRADA DE 1920}

De las tres publicaciones con imágenes que vamos a estudiar en esta investigación esta es la más antigua.

\section{Datos generales}

El título chino, según la trascripción que disponemos, sería "Llu-sin-selio-tou-suo", traducido al castellano como "Historia Sagrada”, publicado en Youchowfu (Shangtung), China en $1920^{55}$. (Ilustración 6)

El libro lleva en su interior el "Nihil Obstat" del P. Aloysius Versiglia, C. S. Superior, y el permiso de impresión del P. J. Da Costa Nunes, Vicario Capitular. Todo ello fechado en Macao el 23 de octubre de 1919.

recen recopiladas en las obras: PEPIN vON RoOJEn (Edit.) Images from the Bible. The Old Testament, The Pepin Press, Amsterdam 2010; PePIn von Roojen (Edit.) Images from the Bible. The New Testament, The Pepin Press, Amsterdam 2010.

${ }^{54}$ Maison de la Bonne Presse, The Catechism in Pictures, Paris 1912, Prefacio.

${ }^{55}$ Llu-sin-se-lio-tou-suo (Historia Sagrada), Youchowfu, Shangtung, 1920. 
En la biblioteca del Estudio Teológico Agustiniano del Real ColegioSeminario de PP. Agustinos de Valladolid, está identificada por un lado con la numeración antigua: 100.589 y, por otro, con la numeración actual: CH 96/3.

Las dimensiones del libro son 19'8 x 12'3 cms., mientras que la dimensiones de los grabados es de 7'3 x 8'8 cms.

La publicación consta de 94 páginas más un mapa. Tras una introducción de dos páginas en chino siguen las 81 imágenes grabadas, 34 de ellas correspondientes al Antiguo Testamento y 47 del Nuevo Testamento. Concluye con el mapa de Palestina.

Todos los grabados llevan un enunciado en la parte superior y un texto explicativo en la parte inferior, todo ello en caracteres chinos.

Desconocemos quiénes han sido los autores de los grabados. Solamente algunos de ellos llevan unas iniciales del grabador. Tenemos entre ellas: El juicio de Salomón, La purificación del templo, grabados por H. M.; La resurrección de la hija de Jairo, firmado en la parte izquierda con las iniciales del grabador C. H.; Jesús atado a la columna, y La Ascensión de Jesús al cielo, firmados por Henri Weber, K. A. Stuttgart... Pero no hemos conseguido descubrir a quién corresponden las diversas iniciales. Dado el estilo de los mismos es evidente que se trata de autores europeos, muy probablemente algunos italianos, y otros alemanes, que han sido reproducidos por los impresores chinos.

En esta edición china de la Historia Sagrada se han copiado 80 grabados de la obra Historia Sagrada del Antiguo y Nuevo Testamento de Ignaz Schuster, de los 114 que aparecen en la obra original alemana. Solamente uno -la aparición de Jesús a la Magdalena-, no está tomado de allí. Por lo que se refiere a las fuentes originales de inspiración de los grabados, algunos de ellos están inspirados -incluso reproducidos casi fielmente- en la obra "Gran Colección de láminas del Antiguo y Nuevo Testamento", realizada por el eminente artista Julius Schnorr von Carolsfeld, de la que tenemos una edición realizada en la imprenta y litografía de Faustino Paluzié de Barcelona en 1885. Algunos otros, como se indicará en su momento, están tomados de obras de Rafael Sanzio, Leonardo da Vinci y Bartolomé Esteban Murillo; pero, de la mayoría, no hemos descubierto hasta ahora el origen último.

\section{Descripción de los grabados}

Pasamos a continuación a estudiar una tras otra las distintas imágenes de la obra. 


\section{1.- La creación (Gen 1-2)}

Preside la escena el Padre Eterno sentado sobre una nube y rodeado de una aureola circular. Su rostro, con abundante barba, está enmarcado dentro de un triángulo. A ambos lados están tres ángeles: uno de ellos toca el arpa, mientras que los otros dos sostienen una cinta en la que se lee: "Credo in unum Deum omnipotentem". Por encima se encuentran las estrellas y la luna.

A ambos lados del grabado están representados dos árboles. En el de la derecha está enroscada una serpiente. En el medio, en la parte baja encontramos a Adán y Eva desnudos que contemplan y veneran al Padre Eterno. La parte inferior de sus cuerpos está cubierta por un arbusto. Detrás de ellos se encuentran 4 pájaros y, delante, dos elefantes, dos ciervos, dos leones, otro ave y un pez en un riachuelo.

\section{2.- La expulsión del paraíso (Gen 3, 23-24)}

"Y lo echó Dios del jardín del Edén para que labrase el suelo de donde había sido tomado. Tras expulsar al hombre, puso delante del jardín de Edén querubines, y la llama de espada vibrante, para guardar el camino del árbol de la vida" (Gen 3, 23-24).

A la puerta del paraíso un ángel, con una espada de fuego en la mano, está expulsando a Adán y Eva vestidos con sencillas túnicas. Adán, compungido, cubre su rostro entre las manos, mientras que Eva le mira triste cruzando sus brazos sobre el pecho. Por la puerta abierta del paraíso puede verse el árbol con el fruto de las manzanas. Del recinto salen huyendo la serpiente -que está a los pies de Adán-, el león y un ciervo.

Por encima, el Padre Eterno, sobre una nube, ordena con su mano la expulsión. En el ángulo superior derecho aparece una pequeña imagen de la Virgen con el Niño pisando la serpiente, rodeada de una aureola brillante y estrellas".

Algunas de las partes del diseño están inspiradas en la lámina nº 10 de Julius Schnorr von Carolsfeld, grabada por Steinbrecher ${ }^{56}$.

\section{3.- Caín y Abel (Gen 4, 9-12)}

"Dios dijo a Caín: ¿Dónde está tu hermano Abel?. Contestó: No sé. ¿Soy yo acaso el guardián de mi hermano? Replicó Dios: ¿Qué has hecho? Se oye la

\footnotetext{
${ }^{56}$ Schnorr von CARolsfeld, Julius, Gran colección de láminas del Antiguo y Nuevo
} Testamento, Grabado n ${ }^{\circ} 10$. 
sangre de tu hermano clamar a mí desde el suelo. Pues bien, maldito seas (...) Vagabundo y errante serás en la tierra..." (Gen 4, 9-12).

En primer plano aparece el cuerpo de Abel tendido en el suelo, que acaba de ser asesinado por su hermano Caín. Detrás, vemos un rebaño de ovejas y los sacrificios que ambos ofrecían a Dios. Uno, el de Abel, de lo mejor del rebaño; el otro, el de Caín, de lo peor. Por encima, entre las nubes, el Padre Eterno airado -rodeado de cuatro ángeles tristes-, condena la acción de Caín, que huye escondiendo su rostro entre las manos.

\section{4.- El arca de Noé (Gen 6, 18-19)}

"Entrarás en el arca tú y tus hijos, tu mujer y las mujeres de tus hijos contigo. $Y$ de todo ser viviente meterás en el arca una pareja para que sobrevivan contigo. Serán macho y hembra" (Gen 6,18-19).

Al lado de unas altas montañas se encuentra el arca de Noé, que es como una gran casa dentro de una barca. Por una rampa de acceso están entrando en ella distintas parejas de animales. Pueden distinguirse: camellos, jirafas, ciervos, elefantes, caballos, toros,... En primer plano, de espaldas, un grupo de ocho personas: la familia de Noé que espera su turno para entrar.

\section{5.- El sacrificio de Noé (Gen $8,20-21)$}

"Noé construyó un altar a Yahvé y tomando de todos los animales (...) ofreció holocaustos en el altar. Al aspirar Yahvé el calmante aroma, dijo en su corazón: "Nunca más volveré a maldecir el suelo por causa del hombre..." (Gen 8,20-21).

Pasado el diluvio, nos encontramos a Noé ofreciendo el sacrificio de un cordero sobre un altar de piedra. Alrededor está su familia. Por encima de las llamas, dentro de una nube, aparece el Padre Eterno que acepta la ofrenda y, como signo de reconciliación, hace surgir el arco iris. Al fondo se puede observar el arca, varada sobre una montaña.

Este grabado está inspirado en la lámina nº 19 de Julius Schnorr von Carolsfeld, grabada por F. Obermann ${ }^{57}$.

\section{6.- La confusión de las lenguas (Gen 11, 8-9)}

"Y los desperdigó Yahvé por toda la faz de la tierra, y dejaron de edificar la ciudad. Por eso se la llamó Babel, porque allí embrolló Yahvé el lenguaje de todo el mundo y desde alli los desperdigó Yahvé por toda la faz de la tierra" (Gen 11, 8-9).

\footnotetext{
${ }^{57}$ SCHNORR vON CAROLSFELD, Julius, Gran colección de láminas, grabado no 19.
} 
Tras la construcción de la Torre de Babel -que aparece al fondo del grabado- el Padre Eterno, rodeado de ángeles dentro de una nube, hace surgir la confusión de las lenguas. Esta lleva a la dispersión de los habitantes. En primer plano parecen tres grupos: unos huyen hacia la izquierda con un burro; al centro, están montando sobre un camello; y a la derecha un tercer grupo acompaña a un joven con espada en mano montado sobre un caballo.

\section{7.- El sacrificio de Melquisedec (Gen 14, 17-20)}

"A su regreso, después de batir a Quedorlaomer y a los reyes que con él estaban, le salió al encuentro el rey de Sodoma (...) Entonces Melquisedec, rey de Salem, presentó pan y vino, pues era sacerdote del Dios Altísimo y le bendijo diciendo..." (Gen 14, 17-20).

Junto a una colina con fortalezas aparece, al lado izquierdo, la figura de Melquisedec, rey de Salem, que lleva una corona sobre la cabeza y que, mirando al cielo, está ofreciendo una fuente de panes y tiene a su lado sobre un altar de piedra un cáliz. Le acompañan otros tres personajes. Uno de ellos es un joven que tiene al lado un cesto de pan y una tinaja, y sostiene un cesto de panes y una jarra. Frente a ellos, arrodillados, aparecen Abrán y toda su tropa, con las lanzas en sus manos, tras su victoria sobre Quedorlaomer. En primer plano, Abrán está adorando la ofrenda del sacerdote, con la rodilla en tierra, la lanza en su mano y los brazos cruzados sobre el pecho.

Este grabado está inspirado en la lámina nº. 25 de Julius Schnorr von Carolsfeld, grabada por F. Reusche. Algunas imágenes son iguales. En otras cambia la postura de las figuras ${ }^{58}$.

\section{8.- La destrucción de Sodoma y Gomorra (Gen 19, 15-26)}

"Al rayar el alba los ángeles apremiaron a Lot diciendo: "Levántate, toma a tu mujer y a tus dos hijas (...) Como él remoloneaba, los hombres le asieron de la mano lo mismo que a su mujer y a sus dos hijas, por compasión de Yahvé hacia él, y sacándolo, lo dejaron fuera de la ciudad" (Gen 19,15-16).

Al fondo del grabado pueden verse envueltas en llamas las ciudades de Sodoma y Gomorra. En primer plano dos jóvenes ángeles acompañan a Lot y a sus hijas en su huida. Los rostros de los personajes reflejan la angustia del momento. En medio, a la derecha, puede verse a la mujer de Lot que, al volver la vista atrás, se convirtió en una estatua de sal.

\footnotetext{
${ }^{58}$ SCHNORR vON CAROLSFElD, Julius, Gran colección de láminas, grabado $\mathrm{n}^{\circ} 25$.
} 
Este grabado podría estar inspirado en la pintura al fresco con este mismo tema, pintada por Rafael Sanzio, en la Logia de los apartamentos papales del Vaticano. De hecho, tiene muchos puntos comunes.

\section{9.- El sacrificio de Isaac (Gen 22, 9-14)}

"Entonces le llamó el Ángel de Yahvé desde el cielo diciendo: ;Abrahán, Abrahán! No alargues tu mano contra el niño, ni le hagas nada, que ahora ya sé que eres temeroso de Dios, ya que no me has negado tu hijo, tu único" (Gen 22,11-12).

El grabado nos muestra el momento cumbre en el que Abrahán está dispuesto a sacrificar a su único hijo Isaac. Este, semidesnudo, con las manos atadas a su espalda, está arrodillado sobre la leña del altar de sacrificio esperando ser ejecutado por su propio padre. Este, con el cuchillo en la mano, se dispone a sacrificarle. Pero, en ese momento, aparece la figura del ángel y se oye la voz divina impidiéndoselo. Por debajo del ángel, entre zarzas, aparece un cordero que será sacrificado en sustitución de Isaac.

Esta obra está inspirada en otra del mismo tema de Julius Schnorr von Carolsfeld, concretamente la lámina $n^{\circ} 28$ de la serie ${ }^{59}$. (Ilustración 7)

\section{0.- José vendido por sus hermanos (Gen 37, 21-36)}

"Pasaron unos madianitas mercaderes y, descubriéndolo, subieron a José del pozo. Vendieron a José por veinte piezas de plata a los ismaelitas que se llevaron a José a Egipto" (Gen 37,28).

La escena representa el momento en el que José es vendido por sus hermanos a los mercaderes ismaelitas. El joven José acaba de ser sacado del pozo en el que le habían arrojado sus hermanos y es entregado a uno de los mercaderes, vestido con una larga túnica y un turbante. Alrededor del pozo están los hermanos. Uno de ellos, Rubén, está recibiendo el precio ajustado por la venta: 20 monedas de plata. Al fondo, se ven pastar los rebaños de ovejas que los hermanos de José estaban cuidando.

\section{1.- José, Primer Ministro de Egipto (Gen 41, 37-43)}

"Dijo el faraón a José: Mira, te he puesto al frente de todo el país de Egipto (...) luego le hizo montar en su segunda carroza, e iban gritando delante de él: ¡Abrek! Así lo puso al frente de todo el país de Egipto” (Gen 41, 42-43).

Tras interpretar los sueños de los cortesanos y los sueños del faraón, José es nombrado Primer Ministro de Egipto. En este grabado se repre-

\footnotetext{
${ }^{59}$ SCHNORR vON CAROLSFeld, Julius, Gran colección de láminas, grabado $\mathrm{n}^{\circ} 28$.
} 
senta a José con ricas vestimentas y una cadena de oro al cuello, montado en un carro triunfal, tirado por dos caballos, mientras que la población lo aclama y se va postrando a su paso.

\section{2.- José se da a conocer a sus hermanos (Gen $45,1-15)$}

"Y, echándose al cuello de su hermano Benjamín lloró; también Benjamín lloraba sobre el cuello de José. Luego besó a todos sus hermanos llorando abrazado a ellos" (Gen 45, 14-15).

El grabado describe el momento del abrazo entre José y su hermano Benjamín, en presencia de los demás hermanos que no salen de su asombro.

Esta imagen está inspirada en el diseño $n^{\circ} 42$ de la Gran Colección de Láminas del Antiguo y Nuevo Testamento de Julius Schnorr von Carolsfeld, grabado por A. Gaber ${ }^{60}$.

\section{3.- La muerte de Jacob (Gen 48 y 49)}

Los capítulos 48 y 49 del Génesis describen la despedida de Jacob, la bendición de sus doce hijos y los dos nietos hijos de José.

En este grabado se representa a Jacob sentado en el lecho y dirigiéndose a sus hijos y nietos. En primer plano, tres de ellos están arrodillados y otros tres de pie. A la cabecera, otro de los hijos le sostiene por la espalda. A la izquierda del lecho, de pie, está José, con una corona en la cabeza, acompañado por sus hijos Manasés y Efraín y, detrás, otros cuatro hermanos.

\section{4.- Moisés es rescatado de las aguas del Nilo (Ex 2, 5-10)}

"Entonces la hija del faraón bajó a bañarse en el río, mientras sus doncellas se paseaban por la orilla del río. Ella divisó la cestilla entre los juncos y envió una criada para que la recogiera. Al abrirla vio que era un niño que lloraba. Se compadeció de él y exclamó: Es un niño de los hebreos” (Ex 2, 5-6).

El grabado nos muestra a la hija del faraón y sus sirvientas contemplando al pequeño Moisés dentro de la cesta. Detrás, entre la maleza, puede verse a la hermana de Moisés que, posteriormente, se ofrecerá para criarlo. Al otro lado del grabado se puede ver una de las pirámides de Egipto.

\section{5.- La zarza ardiente (Ex 3, 1-6)}

“Cuando Yahvé vio que Moisés se acercaba para mirar le llamó de en medio de la zarza (...): No te acerques aquí; quita las sandalias de sus pies, porque el

\footnotetext{
${ }^{60}$ SCHNORR vON CAROLSFEld, Julius, Gran colección de láminas, grabado ${ }^{\circ} 42$.
} 
lugar que pisas es suelo sagrado (...) Moisés se cubrió el rostro porque temía ver a Dios" (Ex 3, 4-6).

Moisés que estaba pastoreando el rebaño de su suegro Jetró ve una zarza ardiendo en el Monte Oreb, la Montaña de Dios, y se acerca a observarla. Este es el momento que nos muestra el grabado. La composición de esta obra está inspirada en la lámina $n^{\circ} 47$ de Julius Schnorr von Carolsfeld ${ }^{61}$.

\section{6.- La celebración de la Pascua $(\mathrm{Ex}$ 12, 1-34)}

El grabado nos muestra la celebración de la Pascua judía. Una familia se encuentra reunida alrededor de una mesa sobre la que está colocado el cordero pascual. Los comensales, unos de pie y otros sentados, se están llevando un bocado de pan a la boca. Una joven, con un cesto de verduras, acompañada de un niño, se está acercando a la mesa. Por la ventana que hay detrás, se ve pasar al ángel exterminador con su espada de fuego que causará la muerte de los primogénitos de los egipcios.

\section{7.- El paso del Mar Rojo (Ex 14, 15-31)}

"Moisés extendió su mano sobre el mar y, al rayar el alba, el mar volvió a su lugar habitual, de modo que los egipcios, en su huida, toparon con él. Así precipitó Yahvé a los egipcios en medio del mar" (Ex 14,27).

Destaca en el grabado la potente figura de Moisés, de pie sobre un promontorio, que está ordenando cerrarse las aguas, después de que el pueblo de Israel haya atravesado en seco el Mar Rojo. Gran parte de los israelitas están en actitud orante, de rodillas, o con las manos juntas agradeciendo a Dios, el verse libres de la esclavitud de Egipto. En la parte izquierda del grabado se ve cómo carros, caballos y soldados del ejército del faraón están intentando no ser engullidos por las aguas.

\section{8.- El maná y el agua de la roca (Ex 16 y 17)}

En esta obra se representan dos episodios de la historia del pueblo de Israel en su peregrinación por el desierto. En la parte izquierda podemos observar la caída del maná del cielo y cómo los israelitas lo están recogiendo. En la parte derecha vemos a Moisés que con su vara ha golpeado la roca de la que está manando agua por dos lugares. Delante, varias per-

\footnotetext{
${ }^{61}$ SCHNORR vON CAROLSFeld, Julius, Gran colección de láminas, grabado no 47.
} 
sonas están recogiendo agua en cuencos y bebiendo. Detrás de Moisés, otros más están en actitud suplicante.

\section{9.- Yahvé entrega el decálogo a Moisés (Ex 19, 16-25; 20, 1-20; 31, 18)}

"Después de hablar con Moisés en el Monte Sinaí, le dio las dos Tablas del Testimonio, tablas de piedra, escritas por el dedo de Dios" (Ex 31,18).

Mientras el pueblo se queda en el llano, en sus tiendas, Moisés sube a la montaña del Sinaí, donde Dios se le revela. En medio de nubes y ángeles con trompetas, Yahvé hace entrega a Moisés de las Tablas de la Ley, con el decálogo. Moisés, arrodillado y en actitud sumisa, las recoge de sus manos. Posteriormente, trasmitirá el mensaje al pueblo.

Este grabado está claramente inspirado en la obra $n^{\circ} 54$ de la Gran Colección de Láminas del Antiguo y Nuevo Testamento de Julius Schnorr von Carolsfeld, grabado por Junctow ${ }^{62}$.

\section{0.- Erección y consagración del santuario (Ex 40, 1-8)}

"El día primero del primer mes alzarás la Morada de la Tienda del Encuentro. Allí pondrás el arca del Testimonio (...) llevarás también el candelabro y pondrás encima las lámparas. Colocarás el altar de oro para el incienso delante del arca del Testimonio (...) Colocarás el altar de los holocaustos ante la entrada (...) Pondrás la pila entre la Tienda del Encuentro y el altar” (Ex 40.1-7).

El grabado nos muestra al pueblo de Israel acampado en sus tiendas, plantadas en un valle, en medio de los montes. Al centro se muestra el santuario del Señor construido según las instrucciones dadas por Dios a Moisés.

\section{1.- La serpiente de bronce (Num 21, 1-9)}

Ante la rebelión del pueblo contra Dios, este les castiga con las serpientes venenosas. Los israelitas acuden a Moisés para que interceda en su favor. Dios les responde del siguiente modo: "Hazte una serpiente abrasadora y ponla sobre un mástil. Todo el que haya sido mordido y la mire, vivirá” (Num 21, 8-9).

En este grabado se muestra, precisamente, a Moisés invitando al pueblo a que miren a la serpiente de bronce para ser sanados de sus picaduras.

\section{2.- La toma de Jericó (Jos 6, 1-21)}

“El pueblo lanzó el alarido y se tocaron las trompetas. Al escuchar el pueblo la voz de la trompeta, prorrumpió en gran alarido, y el muro se vino abajo. La

\footnotetext{
${ }^{62}$ SCHNORR vON CAROLSFeld, Julius, Gran colección de láminas, grabado no 54 .
} 
gente escaló la ciudad, cada uno por el lugar que tenía enfrente, y se apoderaron de ella" (Jos 6, 20).

Aquí se presenta al pueblo de Israel entrando en la ciudad de Jericó, cuyas murallas se están viniendo abajo. El Arca de la Alianza -sobre la que van los ángeles alados-, es precedida por el pueblo y los sacerdotes tocando las trompetas. En primer plano, un jinete a caballo invita al pueblo a avanzar.

\section{3.- David mata al gigante Goliat (1 Sam 17, 40-54)}

"Corrió David, se detuvo sobre el filisteo y tomando la espada de este le cortó la cabeza" (1 Sam. 7,51).

El grabado nos muestra al joven David quien después de haber abatido a tierra a Goliat, toma su espada y se dispone a cortar la cabeza del gigante. Por detrás se ve al ejército de los filisteos que huye entre las montañas, perseguido por los israelitas.

Este grabado es, prácticamente, una copia simplificada de la obra $\mathrm{n}^{\circ}$ 91 de la Gran Colección de láminas del Antiguo y Nuevo Testamento de Julius Schnorr von Carolsfeld, grabada por Zschelckel ${ }^{63}$. (Ilustraciones 8 y 9)

\section{4.- Entrada triunfal del arca de la alianza en Jerusalén (2 Sam 6, 1-8)}

"David y toda la casa de Israel bailaban delante de Yahvé con todas sus fuerzas, cantando con cítaras, arpas,..." (2 Sam 6,5).

El rey David, acompañado de todo el pueblo, traslada en solemne procesión el arca de la alianza a Jerusalén. Delante de ella van los sacerdotes tocando las trompetas. Presidiendo el cortejo, se encuentra el rey David, tocando el arpa.

\section{5.- El juicio de Salomón. (1 Re 3, 16-28)}

"A la mujer de quien era el niño vivo se le conmovieron las entrañas por su hijo y replicó al rey: Por favor, mi señor, que le den a ella el niño vivo, pero matarlo ¡No! ¡No lo matéis!” (1 Re 3, 26-27).

El grabado representa el "Juicio de Salomón”. Dos mujeres se disputan la maternidad de dos niños: uno vivo y el otro muerto. Ambas pretenden que el hijo vivo es el suyo. Para discernir quién es la auténtica madre, Salomón sentencia que corten al niño vivo en dos, y den la mitad a cada una. La auténtica madre suplica al verdugo que no ejecute la sentencia dictada por el rey.

\footnotetext{
${ }^{63}$ SCHNORR VON CAROLSFELD, Julius, Gran colección de láminas, grabado no 91.
} 
Este grabado podría estar inspirado en la pintura al fresco con este mismo tema, pintada por Rafael Sanzio, en la Logia de los apartamentos papales del Vaticano.

Esta obra es una de las pocas que lleva como firma las iniciales del grabador: HM. Aunque no sabemos a quién corresponden dichas iniciales.

\section{6.- La oración de Salomón en el templo (1 Re 8, 22-30)}

"Salomón se puso en pie ante el altar de Yahvé, frente a toda la asamblea de Israel, extendió las manos al cielo y dijo: Yahvé, Dios de Israel, no hay Dios como tú arriba en los cielos ni abajo en la tierra,...” (1 Re 8,22-23).

El rey Salomón ora en el templo que él ha construido, levantando los brazos al cielo delante del altar de los sacrificios, en presencia del pueblo.

\section{7.- EI sacrificio del Carmelo (1Re 18, 20-40)}

"Cayó el fuego de Yahvé que devoró el holocausto y la leña, y lamió el agua de las zanjas. Todo el pueblo lo vio, cayeron rostro en tierra y exclamaron: Yahvé, él es Dios" (1 Re 18,38-39).

En el grabado se muestra al rey Ajab entre el altar de los profetas de Baal y el altar de Elías. En esta disputa para demostrar al pueblo de Israel quién era el verdadero dios, los sacerdotes de Baal -en la esquina superior del grabado-, no consiguen que su dios prenda el fuego. Sin embargo, Elías -a pesar de haber echado agua en el altar y alrededor-, consiguió con su oración la intervención de Dios.

\section{8.- El profeta Elías es arrebatado al cielo (2 Re 2,1-18)}

"Iban caminando y hablando, y de pronto un carro de fuego con caballos de fuego los separó a uno del otro. Elías subió al cielo en la tempestad. Eliseo lo veía y clamaba: ¡Padre mío, padre mío! ¡Carros y caballería de Israel” (2 Re 2, 11-12).

Se nos muestra aquí de una forma muy realista el momento en el que Elías es arrebatado en un carro de fuego, mientras Eliseo en tierra le suplica. El diseño representa a la perfección la dramaticidad del texto bíblico.

Esta obra tiene bastantes similitudes con la $\mathrm{n}^{\circ} 115$ de la gran colección de las láminas de Julius Schnorr von Carolsfeld ${ }^{64}$.

${ }^{64}$ SchnORR von CAROLSFeld, Julius, Gran colección de láminas, grabado no 115 . 


\section{9.- El profeta Jonás es tragado por un gran pez (Jon 2, 1-11)}

"Yahvé hizo que un gran pez se tragase a Jonás, y Jonás estuvo en el vientre del pez tres días y tres noches" (Jon 2,1).

A Jonás le recomiendan la misión de ir a Nínive a predicar la conversión. Pero él intenta huir, angustiado por la responsabilidad. Yahvé hizo que un gran pez lo tragase y después de tres días lo vomitase en tierra firme.

\section{0.- Tobías capturando un pez (Tob 6, 2-6)}

"El ángel le dijo: ;Agarra el pez y tenlo bien sujeto! El muchacho se apoderó del pez y lo arrastró a tierra. El ángel añadió: ;Abre el pez, sácale la hiel, el corazón y el hígado y guárdatelos (...) porque son remedios útiles” (Tob. 6, 4-5).

El grabado recoge el momento en el que Tobías captura el pez, cuyas entrañas le servirán para curar la ceguera de su padre. El joven tiene detrás de él a su perro y al arcángel Rafael.

\section{1.- Lamentaciones de Jeremías (Jer 8, 21-22)}

"Me duele el quebranto de la capital de mi pueblo; estoy abrumado, el pánico se apodera de mí" (Jer 8,21)

El personaje central del grabado, Jeremías, es un anciano que está sentado. Lleva en la mano derecha un rollo de escritura, mientras que con la izquierda sostiene su cabeza. Parece una persona abatida y apesadumbrada. Todo a su alrededor es tristeza y destrucción: edificios derruidos, mujeres con niños muertos, ancianos moribundos, personas abatidas, recostadas en tierra,...

Esta obra tiene bastantes similitudes con la n ${ }^{\circ} 135$ de la gran colección de las láminas de Julius Schnorr von Carolsfeld, grabado por F. Obermann, de Dresden ${ }^{65}$.

\section{2.- Los tres jóvenes salen del horno (Dan 3, 24-28)}

"Nabucodonosor se acercó a la boca de fuego abrasador y dijo: Sidrac, Misac y Abdénago, servidores del Dios Altísimo, salid y venid aquí. Y Sidrac, Misac y Abdénago salieron de entre el fuego" (Dan 3,26).

En esta obra se muestra el momento en el que el rey Nabucodonosor contempla la salida del horno de fuego de los tres jóvenes hebreos, acompañados por un ángel.

${ }^{65}$ SCHNORR VON CAROLSFELD, Julius, Gran colección de láminas, grabado n ${ }^{\mathrm{o}} 135$. 


\section{3.- Daniel en el foso de los leones (Dan 6, 17-25)}

“¿Ha podido tu Dios, a quien sirves tan fielmente, librarte de los leones? Y Daniel respondió (...): Mi Dios ha enviado a un ángel que ha cerrado la boca de los leones y no me han hecho daño, porque soy inocente ante él, como tampoco he hecho nada contra ti" (Dan 6,21-23).

De forma gráfica es representado el episodio de Daniel dentro de la fosa de los leones. El está en medio sentado tranquilamente, sin sufrir ningún tipo de agresión por parte de los leones, que están recostados pacíficamente en el suelo. Por la parte derecha aparece un ángel junto con un acompañante que lleva en su mano un recipiente con comida.

\section{4.- Sacrificio de los hermanos Macabeos (2 Mac 7)}

"Te ruego hijo que mires al cielo y a la tierra y, al ver todo lo que hay en ellos, sepas que a partir de la nada lo hizo Dios (...) No temas a este verdugo, antes bien, mostrándote digno de tus hermanos, acepta la muerte, para que vuelva yo a encontrarte con tus hermanos en la misericordia" (2Mac 7,28-29).

Los siete hermanos Macabeos rechazan comer la carne de cerdo que les estaba prohibida por la ley, por lo que el rey Antioco ordena que les quiten la vida. El grabado nos muestra al rey Antioco ordenando el martirio, así como a uno de los hermanos ya muerto en el suelo, otro que está siendo víctima del fuego y las torturas. En primer plano, se ve a la madre que consuela a su hijo más joven y le anima a ser valiente y no renegar de su fe, siguiendo la suerte de sus hermanos.

\section{5.- Anunciación a Zacarías (Lc 1, 5-20)}

"El ángel le dijo: No temas, Zacarías, porque tu petición ha sido escuchada. Isabel, tu mujer, te dará un hijo a quien pondrás por nombre Juan” (Lc 1,13).

Mientras Zacarías estaba ejerciendo su ministerio sacerdotal en el templo, recibe la visita de un ángel. Este es el momento que recoge el grabado. Zacarías, vestido de sacerdote, con el incensario en la mano, está delante de una mesa con panes ácimos y del altar del Señor, con el candelabro de los siete brazos. Por el lado derecho aparece un joven ángel radiante, que le anuncia el nacimiento de su hijo Juan el Bautista.

En esta obra, las posturas de Zacarías y el ángel son casi iguales a las del grabado $n^{\circ} 153$ de la Gran colección de láminas del Antiguo y Nuevo Testamento pintadas por Julius Schnorr von Carolsfeld, y grabada por Steinbrecher. (Ilustraciones 10 y 11) 


\section{6.- Anunciación a María (Lc 1, 26-38)}

"Envió Dios el ángel Gabriel (...) a una virgen, desposada con un hombre llamado José, de la casa de David; el nombre de la virgen era María" $(\operatorname{Lc} 1,26)$.

El ángel Gabriel, con un lirio en la mano, se aparece a María. Esta se encuentra arrodillada y orante con los brazos abiertos. El ángel le anuncia que "concebirá y dará a luz un hijo a quien pondrá por nombre Jesús" (Lc 1,31). Ella acepta: "He aquí la esclava del señor. Hágase en mí según tu palabra” (Lc 1, 38). En el grabado vemos al Espíritu Santo, representado en forma de paloma, que está descendiendo sobre María.

La postura del ángel nos recuerda a la anunciación de Hieronimus Wierix, en la obra “ Evangelicae Historiae Imágines” de Jerónimo Nadal ${ }^{66}$.

\section{(Ilustraciones 12 y 13)}

\section{7.- La Visitación (Lc 1, 39-45)}

"María se puso en camino y se fue con prontitud a la región montañosa a una ciudad de Judá; entró en casa de Zacarías y saludó a Isabel" (Lc 1,39-40).

Se nos muestra el momento en el que María se encuentra con su prima Isabel. Ambas se abrazan. Isabel se inclina ante María. Se las ve conversando, intercambiándose el saludo. Por detrás se observan las colinas. A la derecha aparece Zacarías en el umbral de la puerta de su casa, que está saliendo para dar la bienvenida a María.

En esta obra, se encuentran ciertos parecidos con el grabado $\mathrm{n}^{\circ} 153 \mathrm{de}$ la Gran colección de láminas del Antiguo y Nuevo Testamento pintadas por Julius Schnorr von Carolsfeld, y grabada por A. Gaber ${ }^{67}$.

\section{8.- Nacimiento de Jesús y visita de los pastores (Lc 2, 1-20)}

"Los pastores se decían unos a otros: ¡Vamos a Belén a ver lo que ha sucedido

y el Señor nos ha manifestado! Fueron a toda prisa y encontraron a María, a José y al niño acostado en el pesebre" (Lc 2,15-16).

En esta escena María y José muestran a Jesús niño a los pastores. El primero de ellos tiene un cordero a sus pies. Está arrodillado en actitud orante. Los otros están de pie. Desde lo alto desciende un haz de luz al lado del cual hay cuatro cabezas de ángeles con alas. Detrás de la Sagrada Familia, en la penumbra, pueden apreciarse las cabezas del buey y la mula.

\footnotetext{
${ }^{66}$ NADAL, Jerónimo, Evangelicae Historiae Imagines, Amberes 1593, grabado 1.

${ }^{67}$ SCHNORR VON CAROLSFELD, Julius, Gran colección de láminas, grabado no 153.
} 


\section{9.- Presentación de Jesús en el templo (Lc 2, 22-38)}

"Simeón, movido por el Espíritu Santo vino al templo y, cuando los padres introdujeron al niño Jesús, para cumplir lo que la ley prescribía sobre él, le tomó en sus brazos y bendijo a Dios diciendo...” (Lc 2, 27-28).

Con ocasión de la presentación de Jesús en el templo, María pone al niño en manos de Simeón. Al lado de este, medio agazapada y observando, está la profetisa Ana, junto con otra mujer. En el lado izquierdo, con una paloma entre sus manos, se encuentra San José, que mira tiernamente al niño. En el fondo de la escena se puede observar una figura de Moisés con las tablas de la ley y, a los lados, en la pared dos antorchas encendidas.

\section{0.- Huida a Egipto (Mt 2 13-15)}

"Él (José) se levantó, tomó de noche al niño y a su madre y se retiró a Egipto, y estuvo allí hasta la muerte de Herodes" (Mt 2,14-15).

Montada sobre un asno, la Virgen María viaja con el Niño Jesús entre sus brazos, hacia del exilio de Egipto. A su lado, caminando con los pies descalzos, le acompaña san José, que lleva al hombro una vara de la que cuelga un pequeño bulto con algunas pertenencias. Detrás de ellos, a un lado, vemos un paisaje de palmeras y, al otro, una estatua rota, parte de la cual ha caído en el suelo.

Esta imagen nos recuerda una pintura de Murillo sobre el mismo tema, muy similar en la composición. (Ilustraciones 14 y 15)

\section{1.- Jesús entre los doctores (Lc 2, 41-50)}

"Al cabo de tres días lo encontraron en el templo sentado en medio de los maestros, escuchándoles y haciéndoles preguntas, todos los que le oían estaban estupefactos por su inteligencia y sus respuestas" (Lc 2,46-47).

Sentado entre los doctores, Jesús -con un rollo de la ley en la manoresponde a uno de ellos que le está apuntando con el dedo. Son ocho los maestros representados, unos de pie y otros sentados, algunos de ellos con sus pergaminos en la mano. Por la parte derecha de la escena se introducen las figuras de José y María, quien intenta atraer la atención de Jesús, que se muestra absorto en la discusión.

\section{2.- Bautismo de Jesús (Lc 3, 21-22)}

"Jesús, ya bautizado, se hallaba en oración. Se abrió el cielo, bajó sobre él el Espíritu Santo en forma corporal, como una paloma y vino una voz del cielo: Tú eres mi Hijo. Yo hoy te he engendrado" (Lc 3, 21-22). 
A orillas del río Jordán vemos a Jesús arrodillado en oración, delante de Juan el Bautista, después de ser bautizado por este. Desde el cielo está descendiendo la paloma del Espíritu Santo.

\section{3.- Las bodas de Caná (Jn 2, 1-12)}

"Había allí seis tinajas de piedra puestas para las purificaciones de los judíos, de dos o tres medidas cada una. Les dice Jesús: Llenad las tinajas de agua. Y las llenaron hasta arriba" (Jn 2, 6-7).

En la parte izquierda del grabado pueden verse a los esposos dentro de la sala del banquete, toda ella engalanada. Están brindando, con una copa de vino en la mano. En primer plano, al centro, la figura de María en actitud suplicante. Delante de ella, Jesús está dando órdenes a dos criados para que llenen de agua las tinajas que tienen delante. Ellos están ejecutando el encargo. Posteriormente, como nos narra el evangelista, Jesús efectúa el milagro de la transformación del agua en vino, con gran asombro de los comensales.

\section{4.- La purificación del templo (Jn 2, 13-22)}

"Haciendo un látigo con cuerdas echó a todos fuera del templo, con las ovejas y los bueyes; desparramó el dinero de los cambistas y les volcó las mesas y dijo a los que vendían palomas: Quitad esto de aquí. No hagáis de la casa de mi padre una casa de mercado" (Jn 2, 15-16).

Jesús, en primer plano, con el látigo en la mano derecha, vuelca la mesa de un cambista y vemos caerse las monedas. Por detrás escapa una mujer con un cesto de palomas, y otra más se agacha con su jaula. Por detrás, otros dos hombres se alejan con su buey.

Volvemos a encontrar aquí de nuevo la firma del grabador H. M.

\section{5.- Jesús curando enfermos $(L c 4,40)$}

"A la puesta del sol todos cuanto tenían enfermos de diversas dolencias se los llevaban; y él, poniendo las manos sobre cada uno de ellos, los curaba” (Lc 4, 40).

En la parte superior pueden observarse los últimos rayos del sol que se está ocultando tras las montañas. Al centro, al pie de una larga escalinata, vemos que se están acercando a Jesús todo tipo de enfermos; ciegos, cojos, sordos, paralíticos,... Jesús les cura tocándoles con su mano. El diseño alude también al episodio de la hemorroísa (Lc 8, 43-48), al mostrarnos, en penumbra, una mujer tocando el manto de Jesús. 


\section{6.- Pesca milagrosa y vocación de Pedro (Lc 5, 4-11)}

“Al verlo, Simón Pedro cayó a las rodillas de Jesús diciendo: Aléjate de mí, Señor, que soy un hombre pecador. Pues el asombro se había apoderado de él y de cuantos con él estaban, a causa de los peces que habían pescado" (Lc 5,8-9).

Este grabado traslada con fidelidad, en imágenes, lo narrado por el evangelista Lucas. Este diseño reproduce con fidelidad uno de los cartones de Rafael Sanzio que se encuentra expuesto en el "Victoria and Albert Museum” de Londres. En la barca repleta de peces, está a un lado Jesús, sentado. Frente a él, arrodillado, Pedro, reconociéndose pecador. Detrás, Santiago y Juan, los hijos de Zebedeo. Por encima de ellos, se ven sobrevolando un grupo de aves. (Ilustraciones 16 y 17)

\section{7.- El sermón de la montaña (Mt 5 1-11)}

"Viendo la muchedumbre subió al monte, se sentó y sus discípulos se acercaron. Y, tomando la palabra, les enseñaba diciendo: Bienaventurados los pobres de espíritu,..." (Mt 5,1-3).

Jesús está sentado sobre un montículo, enseñando. Detrás de él se ve al grupo de los apóstoles, y, en la parte izquierda frente a Jesús, hombres, mujeres y niños que escuchan atentamente. Unos están recostados en el suelo, otros de pie.

\section{8.- Resurrección del hijo de la viuda de Naín (Le 7, 11-17)}

"Joven, a ti te lo digo: ; Levántate! El muerto se incorporó y se puso a hablar, y él se lo entregó a su madre" (Lc 7,14-15).

En el grabado se representa al fondo la ciudad de Naín y la puerta de la muralla. En primer plano, Jesús acaba de dirigirse al joven, quien, ya despierto está dando la mano a su madre, ante la admiración de todos los acompañantes al duelo.

\section{9.- La mujer pecadora unge los pies de Jesús (Lc 7, 36-50)}

"Llevó un frasco de alabastro de perfume y, poniéndose detrás a los pies de él, comenzó a llorar, y con sus lágrimas le mojaba los pies, y con los cabellos de su cabeza se los secaba; besaba sus pies y los ungía con el perfume” (Lc 7,37-38).

Estando a la mesa en casa del fariseo Simón, una mujer pecadora entró y, postrándose en tierra, se puso a ungirle los pies con perfume y a besarle. Al otro lado de la mesa, Simón y los otros compañeros fariseos están criticando este comportamiento para sus adentros. La escena dará pie a Jesús para dialogar después sobre los dos deudores. 


\section{0.- Jesús predicando desde la barca $(\operatorname{Lc~5,1-3)}$}

"Estaba él a la orilla del lago Genesaret y la gente se agolpaba a su alrededor para oír la palabra de Dios (...) Subiendo a una de las barcas, que era de Simón, le rogó que se alejase un poco de tierra; y, sentándose, enseñaba desde la barca a la muchedumbre” (Jn 5,1-3).

En el grabado se observa, en primer plano, a Pedro y Jesús sentados sobre la barca a la orilla del lago de Genesaret. Frente a ellos, en tierra, un grupo de gente escucha la predicación del maestro. Destacan en primera fila algunas mujeres, con sus hijos en brazos.

\section{1.- Jesús dormido, en medio de la tempestad (Le 8, 22-25)}

"Mientras ellos navegaban, se quedó dormido. Se abatió sobre el lago una borrasca; la barca se anegaba y estaban en peligro. Entonces, acercándose le despertaron diciendo: ;Maestro, Maestro, nos hundimos! (Lc 8,24-24).

El grabado muestra el dramático momento en el que los apóstoles intentan mantener a flote la barca, en medio de la tempestad. Contrasta que, mientras ellos están angustiados, Jesús duerme plácidamente. Después de despertarle Jesús recriminará su falta de fe. Ellos quedan maravillados pues “¿Quien es este que conmina a los vientos y al agua y le obedecen? (Lc 8,25).

\section{2.- Resurrección de la hija de Jairo (Lc 8, 48-56)}

"Él, tomándola de la mano, dijo en voz alta: Niña, levántate. Retornó el espíritu a ella, y, al punto, se levantó, y él mandó que la dieran de comer” (Lc 8, 54-55)

En esta grabado vemos a Jesús, acompañado de Pedro, Juan y Santiago, que ha entrado en la habitación donde estaba muerta la niña. A los pies del lecho, arrodillado, está Jairo y, a la cabecera, la madre de la niña. La imagen representa el momento en el que Jesús la vuelve a la vida.

En esta obra, las posturas de la niña, Jesús y los apóstoles son casi iguales a las del grabado ${ }^{\circ} 176$ de la Gran colección de láminas del Antiguo y Nuevo Testamento pintadas por Julius Schnorr von Carolsfeld.

Este grabado está firmado en la parte izquierda con las iniciales del grabador C. H., de quien desconocemos su identidad.

\section{3.- La decapitación de Juan el Bautista (Mt 14, 3-12)}

"El rey (...) envió a decapitar a Juan en la cárcel. Su cabeza fue traída en una bandeja y entregada a la muchacha, la cual se la llevó a su madre" (Mt 14,10-11). 
Juan Bautista está en las mazmorras con los pies encadenados a una piedra. Puesto de rodillas, dirige su mirada hacia la luz y, con las manos juntas, ora, instantes antes de ser decapitado. Detrás de él, el verdugo, con la espada en alto, está a punto de cortarle el cuello. Al fondo, en el dintel de la puerta, una joven, con una bandeja en la mano, está a la espera, para poder llevar la cabeza del Bautista a Herodías, la mujer de Herodes. (Ilustración 18)

\section{4.- La multiplicación de los panes (Lc 9, 12-17)}

"Levantando los ojos al cielo pronunció sobre ellos la bendición, los partió y los iba dando a los discípulos para que los fueran sirviendo a la gente” (Lc 9, 16).

En este grabado se nos muestra a Jesús sentado sobre una piedra, con los discípulos a su espalda, en el momento de realizar el milagro de la multiplicación de los panes y los peces. Tiene delante de él, arrodillado, un joven con un cesto en el que se encuentran cinco panes y dos peces. Por detrás, toda una multitud hambrienta que le sigue para escuchar su mensaje.

\section{5.- Profesión de fe y primado de Pedro (Mt 16, 13-20)}

"Tú eres Pedro, y sobre esta piedra edificaré mi iglesia, y las puertas del hades no prevalecerán contra ella" (Mt 16,18).

La obra nos muestra el momento en el que Jesús le dice a Pedro estas palabras. Pedro está arrodillado ante Jesús. Éste, con la mano izquierda, le entrega las llaves, mientras que, con la mano derecha, le está indicando la imagen de una iglesia, construida sobre una roca en medio del mar. Detrás de Jesús se pueden ver tres de los apóstoles que asisten de pie. (Ilustración 19)

\section{6.- La transfiguración (Lc 9, 28-36)}

"Mientras oraba el aspecto de su rostro se mudó, y sus vestidos eran de una blancura fulgurante. $Y$ he aquí que conversaban con él dos hombres que eran Moisés y Elías" (Lc 9, 29-30).

Este grabado es, sencillamente una copia, al inverso, de la parte superior de la pintura de Rafael Sanzio sobre este tema que se encuentra en el Vaticano. En la parte de arriba destaca la figura de Jesús, resplandeciente, y como volando en el aire. A su lado las figuras de Moisés y Elías. En la parte inferior, deslumbrados por el resplandor, están tumbados en el suelo los apóstoles Pedro, Juan y Santiago. (Ilustraciones 20 y 21) 


\section{7.- EI Buen Samaritano (Lc 10, 29-37)}

"Pero un samaritano que iba de camino llegó junto a él, y al verle tuvo compasión. Acercándose vendó sus heridas, echando en ellas aceite y vino, y le montó luego sobre su propia cabalgadura, le llevó a una posada y cuidó de él" (Lc 10, 33-34).

En primer plano se encuentra la víctima, a la que han robado y maltratado, dejándolo maltrecho, tumbado en el suelo. A ella se acerca compasivo un anciano samaritano dispuesto a ayudarle. Tiene a su lado una cabalgadura, con la que trasladará al herido hasta la posada. Por el lado derecho, se observa un camino ascendente, entre montañas, en el que todavía podemos ver al sacerdote y al levita que pasaron previamente, siendo indiferentes ante la víctima. (Ilustración 22)

\section{8.- El hijo pródigo (Lc 15, 11-31)}

"Estando todavía lejos, le vio su padre y, conmovido, corrió, se echó a su cuello y le besó efusivamente" (Lc 15,20).

El hijo pródigo llega a casa descalzo, hambriento y mal vestido. El padre se inclina hacia él y lo abraza lleno de amor y de ternura. Detrás del padre, se ve al perro que salta de alegría por la vuelta a casa del joven. En lo alto, entre las nubes, un coro de ángeles se alegra también por el acontecimiento. Por el lado izquierdo, a la entrada de la casa, un sirviente está trayendo una túnica nueva para el recién llegado.

En esta obra, encontramos muchos aspectos inspirados en el grabado n 190 de la Gran colección de láminas del Antiguo y Nuevo Testamento pintadas por Julius Schnorr von Carolsfeld ${ }^{68}$. (Ilustración 23)

\section{9.- El pobre Lázaro (Lc 16, 19-31)}

"Un pobre, llamado Lázaro que, echado junto a su portal, cubierto de llagas, deseaba hartarse de lo que caía de la mesa del rico,.. pero hasta los perros venían y le lamían las llagas" (Lc 16, 20-21).

Lázaro está sentado en el suelo, semidesnudo y lleno de llagas, al pie de la escalinata de la mansión del rico. Con sus manos juntas está mendigando una limosna. Su único auxilio son dos perros que le están lamiendo las heridas. Esta escena contrasta con la parte superior, en la que se puede observar a un grupo de personas, elegantemente vestidas, que están comiendo y bebiendo opíparamente.

${ }^{68}$ SCHNORR vON CAROLSFELD, Julius, Gran colección de láminas, grabado no 190. 


\section{0.- Jesús y los niños (Lc 18, 15-17)}

"Dejad que los niños vengan a mí, y no se lo impidáis, porque de los que son como estos es el reino de los cielos" (Lc 18, 16).

A las afueras de la ciudad, en un descampado, encontramos a Jesús rodeado de niños, a los que se está dirigiendo. Alrededor de este grupo se encuentran las madres que contemplan la escena con satisfacción.

\section{1.- La resurrección de Lázaro (Jn 11, 1-43)}

"Gritó con fuerte voz: ;Lázaro, sal afuera! Y salió el muerto, atado de pies y manos con vendas y envuelto el rostro en un sudario. Jesús les dice: ;Desatadlo y dejadle andar" (Jn 11, 43-44).

A la derecha aparece la figura de Lázaro envuelto en vendas. Frente a él, de pie, la imagen de Jesús que le invita a salir. En medio, arrodilladas, las dos hermanas, Marta y María. A las espaldas de Jesús están un grupo de personas que observan asombradas.

\section{2.- Entrada triunfal de Jesús en Jerusalén (Jn 12, 12-19)}

"Al enterarse la numerosa muchedumbre que había venido para la fiesta de que Jesús se dirigía a Jerusalén, tomaron ramas de palmera y salieron a su encuentro gritando: ¡Hosanna! Bendito el que viene en nombre del Señor! (Jn 12, 12-13).

Jesús, montado sobre un asno, entra triunfante en Jerusalén. Con su mano derecha bendice a la multitud. Algunas personas cubren el suelo con sus mantos. Hombres, mujeres y niños gritan "Hosanna", llevando palmas en sus manos. Desde las casas adyacentes a la calle por donde pasa se asoman las personas aclamándole. A la izquierda dos fariseos miran con suspicacia el acontecimiento.

\section{3.- Parábola de las diez vírgenes (Mt 25, 1-13)}

"Llegó el novio, y las que estaban preparadas entraron con él al banquete de boda y se cerró la puerta" (Mt 25,10).

El grabado interpreta la parábola de las diez vírgenes en clave cristológica. Cristo, resplandeciente de luz, aparece en el dintel de la puerta de la casa, dando la bienvenida a las cinco vírgenes prudentes. Estas llevan una corona de flores en la cabeza y, en sus manos, la lámpara encendida y las alcuzas de aceite. Al otro lado, desconsoladas, aparecen las vírgenes necias con sus lámparas apagadas, y tristes por no poder entrar en el banquete de bodas. 


\section{4.- El lavatorio de los pies (Jn 13, 1-15)}

"Luego echa agua en un librillo y se puso a lavar los pies de los discípulos y a secarlos con la toalla con que estaba ceñido" (Jn 13,5).

Jesús, arrodillado en tierra, está lavando en una palangana los pies de los doce apóstoles. Todos ellos observan pensativos la acción de Jesús. Posteriormente, Jesús les dirá: "Si yo, el Maestro y el Señor, os he lavado los pies, vosotros debéis también lavaros los pies unos a otros" $(\mathrm{Jn} 13,14)$.

\section{5.- La última cena (Lc 22, 14-38)}

"Cuando llegó la hora se puso a la mesa con los apóstoles y les dijo: Con ansia he deseado comer esta Pascua con vosotros antes de padecer" $(\mathrm{Lc} 22,14)$.

Jesús y sus discípulos son representados sentados a la mesa al estilo europeo. Sobre la mesa no se ven más que unos platos, copas y trozos de pan. Los apóstoles parece que están interrogando a Jesús sobre quién es el traidor. Judas aparece a la izquierda del grabado mirando a Jesús y con la bolsa del dinero en su mano derecha, puesta sobre la mesa.

La postura de Jesús y de los dos grupos de tres apóstoles a su derecha e izquierda está claramente inspirado en La Última Cena de Leonardo da Vinci. (Ilustraciones 24 y 25)

\section{6.- La oración del huerto (Lc 22, 39-46)}

"iPadre, si quieres, aparta de mí esta copa, pero no se haga mi voluntad, sino la tuya! Entonces se le apareció un ángel venido del cielo que le confortaba” (Lc $22,42-43)$.

La escena nos muestra a Jesús, angustiado, orando al Padre en el Huerto de los Olivos. Mientras está de rodillas y con las manos juntas orando, se le aparece un ángel. En primer plano, en la parte inferior, en penumbra, aparecen tres de los apóstoles, recostados en el suelo y durmiendo profundamente.

\section{7.- Negaciones de Pedro (Lc 22, 54-62)}

"Este también estaba con él." Pedro lo niega diciendo: Mujer, no le conozco" (Lc 22, 56-57).

En este grabado se nos muestran dos momentos del itinerario de la pasión de Jesús. Al fondo, se representa a Jesús de pie, maniatado, que es interrogado por el sumo sacerdote Caifás, quien está sentado en un trono, rodeado por otros escribas y ancianos. Por la parte baja, en primer plano, 
tenemos a Pedro calentándose en la hoguera, junto con un grupo de soldados. En este momento es abordado por una joven criada que le reconoce como discípulo de Jesús, pero él lo niega.

\section{8.- Jesús atado a la columna (Mt 27, 26)}

“A Jesús, después de azotarle, se lo entregó para que fuera crucificado” (Mt 27, 26).

El grabado nos muestra a Jesús con el torso desnudo, maniatado a una columna, que se encuentra al centro de una estancia de piedra. Tres verdugos, con los látigos en la mano, le están azotando. Jesús, con la cabeza inclinada, aguanta pacientemente el castigo.

Encontramos en esta obra la firma de Urine Weber R., de Stuttgart, que nos indica que se trata de un grabador alemán.

\section{9.- "Ecce Homo" (Jn 19, 1-7)}

"Salió entonces Jesús fuera, llevando la corona de espinas y el manto de púrpura. Díceles Pilato: Aquí tenéis al hombre. Cuando lo vieron los sumos sacerdotes y los guardias, gritaron: „Crucificalo! ¡Crucifícalo!” (Jn 19, 5-6).

Jesús, de pie, maniatado y con la corona de espinas, es presentado por Pilato a la multitud, desde lo alto de un estrado. La gente, desde la parte baja de una escalinata, está gritando para que sea condenado a muerte.

\section{0.- Jesús camino del calvario (Lc 23, 26-28)}

"Hijas de Jerusalén, no lloréis por mí; llorad más bien por vosotras y por vuestros hijos" (Lc 23, 28).

Jesús, con la cruz a cuestas, va camino del calvario. Un esbirro lo lleva atado por la cintura. Por detrás se ven algunos soldados. Después de salir por la puerta de la ciudad Jesús se dirigió a un grupo de mujeres que se compadecían de él.

\section{1.- Crucificado entre dos ladrones (Lc 23, 33-46)}

"Llegados al lugar llamado Calvario le crucificaron allí a él y a los malhechores, uno a la derecha y otro a la izquierda" (Lc 23,33).

Jesús, crucificado entre los dos ladrones, parece estar dirigiendo la palabra al que tiene a la derecha, asegurándole: "Hoy estarás conmigo en el Paraíso” (Lc 23, 43). Un soldado está a punto de atravesarle el costado con una lanza. Juan, la Magdalena, María su madre, y otras santas mujeres están al pie de la cruz. Todo alrededor hay varios soldados y multitud de gente. 


\section{2.- Sepultura de Jesús (Lc 23, 50-56)}

"José de Arimatea (...) se presentó a Pilato, le pidió el cuerpo de Jesús, y, después de descolgarle, le envolvió en una sábana y le puso en un sepulcro excavado en la roca, en el que nadie había sido puesto todavía” (Lc 23,52-53).

$\mathrm{Al}$ fondo del grabado se contempla el monte Calvario con las tres cruces vacías. En primer plano puede verse el cuerpo de Jesús que está siendo preparado para la sepultura. José de Arimatea le está quitando los clavos y la corona de espinas. Detrás, Nicodemo, tiene en la mano un vaso de ungüentos. Arrodillada, al lado del cuerpo de Jesús, está María Magdalena, que está besando su mano. Detrás, se encuentra la Virgen María con el rostro adolorado, y tres de las santas mujeres. A la izquierda, puede verse una sepultura cavada en la roca donde será depositado el cuerpo de Jesús.

\section{3.- La resurrección de Jesús (Mc 16,9)}

“Jesús resucitó en la madrugada, el primer día de la semana” (Mc 16,9).

La resurrección de Jesús es representada aquí con una imagen de Cristo triunfante, radiante de luz, que lleva el estandarte en la mano, y está saliendo de la tumba. A la puerta del sepulcro un ángel lo contempla. En primer plano, los tres soldados que estaban de guardia, se están despertando sobresaltados.

\section{4.- Aparición de Jesús a María Magdalena (Jn 20, 11-18)}

“No me toques! Que todavía no he subido al Padre” (Jn 20, 17).

En la penumbra, dentro del sepulcro, se encuentra un ángel al lado del sudario que está arrojado encima del sepulcro. Fuera, Jesús resucitado, con una pala al hombro y, frente a él, María Magdalena. Ésta, arrodillada -con un vaso de perfume a su lado-, piensa en un principio, que se trata del jardinero. Al oír que Él la llama por su nombre -¡María!, se da cuenta que es Jesús resucitado en persona. Abre sus brazos para intentar abrazarlo, pero Jesús se lo impide.

Este grabado es más grande que el resto. Mide 11'8 x 7'8 cms. y ocupa casi la totalidad de la página.

\section{5.- ¡Apacienta mis corderos! ( Jn 21, 15-19)}

"Después de haber comido, dice Jesús a Simón Pedro: Simón de Juan, ¿me amas más que estos? Le dice él: Sí, Señor, tú sabes que te quiero." Le dice Jesús. Apacienta mis corderos" (Jn 21,15). 
Tras la resurrección, Jesús se apareció a los apóstoles en varias ocasiones. En una de ellas, junto al lago de Tiberíades, después de haber comido con ellos, se dirige a Pedro y le pregunta por tres veces si le ama, y le encomienda que apaciente su rebaño. Aquí en este grabado vemos a Pedro arrodillado delante de Jesús que tiene en su mano un cayado y, a su alrededor, un rebaño de corderos. En el lado derecho, detrás de Pedro, aparecen las figuras de cuatro de los apóstoles.

\section{6.- La Ascensión de Jesús (Lc 24, 50-53)}

"Les sacó hasta cerca de Betania y alzando sus manos, les bendijo y, mientras les bendecía, se separó de ellos y fue elevado al cielo" (Lc 24, 50-51).

En el grabado vemos a Jesús elevándose hacia el cielo, acompañado de dos ángeles. En la parte baja, al fondo, aparece el Monte Calvario con las tres cruces vacías. En primer plano, los apóstoles, que, junto con María, contemplan la Ascensión de Jesús a los cielos.

También aquí en este grabado encontramos la firma de Heina Weber, A. Stuttgart.

\section{7.- La venida del Espíritu Santo (Hech 2, 1-13)}

"Al llegar el día de Pentecostés, estaban todos reunidos con un mismo objetivo. De repente, vino del cielo un ruido, como una impetuosa ráfaga de viento, que llenó toda la casa en la que se encontraban. Se les aparecieron unas lenguas como de fuego que se repartieron y se posaron sobre cada uno de ellos; se llenaron todos de Espíritu Santo" (Hech 2, 1-4).

Este grabado nos muestra a los once apóstoles reunidos en oración, con María en el centro, en el momento de recibir el Espíritu Santo, en forma de llamas de fuego.

\section{8.- La muerte de Esteban (Hech 7, 55-60)}

"Mientras le apedreaban, Esteban hacía esta invocación: "Señor Jesús, recibe mi espíritu. Después dobló las rodillas y dijo con fuerte voz: Señor, no les tengas en cuenta este pecado. Y diciendo esto, murió" (Hech 7,59-60).

Este grabado escenifica la muerte de Esteban, el primer mártir cristiano. Se le muestra arrodillado, con los brazos alzados al cielo en oración mientras, detrás de él, tres personas le están apedreando. En la parte derecha se ve a un joven -probablemente Saulo-, que está recogiendo piedras del suelo para arrojarlas sobre Esteban. (Ilustración 26) 


\section{9.- La vocación de Saulo (Hech 9, 3-6)}

"Yendo de camino, cuando estaba cerca de Damasco, de repente le envolvió una luz venida del cielo, cayó en tierra y oyó una voz que le decía: Saulo, Saulo ¿Por qué me persigues? Él preguntó: ¿Quién eres Señor? Y Él dijo: Yo soy Jesús a quien tú persigues" (Hech 9, 3-5).

El grabado refleja este momento. Pablo está tumbado en el suelo deslumbrado por una luz que viene del cielo, donde, entre nubes y ángeles aparece la figura de Dios que le está interrogando:“¿Por qué me persigues?”. En la penumbra, por un lado podemos ver los compañeros de viaje de Pablo que huyen y, por otro, un caballo que se aleja al galope. (Ilustración 27)

\section{0.- Concilio de Jerusalén (Hech 15, 5-35)}

Pablo y Bernabé, desde Antioquía subieron a Jerusalén, pues “algunos de la secta de los fariseos, que habían abrazado la fe, se levantaron para decir que era necesario circuncidar a los gentiles (...)Después de una larga discusión Pedro se levantó y dijo (...) hemos decidido el Espíritu Santo y nosotros no imponeros más cargas que las indispensables" (Hech 15, 5-29).

En el grabado se nos muestra al apóstol Pedro de pie predicando, con un libro en la mano izquierda. Todo alrededor, le escuchan atentamente un grupo de personas. Los más alejados están de pie; los más cercanos están sentados, algunos de ellos con libros y pergaminos en la mano.

\section{1.- Pantocrátor}

El grabado nos muestra a Jesucristo sentado con un báculo en su mano izquierda y un libro en su mano derecha, con las letras Alfa y Omega. Está rodeado por un círculo luminoso, alrededor del cual están los símbolos de los cuatro evangelistas: el león de Marcos, el toro de Mateo, el ángel de Lucas y el águila de Juan. En la parte superior, varios ángeles en vuelo. A los lados del Pantocrátor se encuentran dos filas de personajes. En la superior, a un lado, están san Pedro y san Pablo y, al otro, dos apóstoles, uno con un cuchillo y otro con un pergamino. En la otra fila, a la izquierda podemos ver a la Virgen, san José, y la Magdalena y, a la derecha, a Moisés, David y Juan Bautista.

\section{2.- Mapa de Palestina}

En este mapa de Palestina se localizan las principales ciudades, así como el lago de Tiberíades, el río Jordán y el Mar Rojo. Con caracteres chinos se identifican los nombres de los lugares geográficos respectivos.

El mapa tiene una dimensión de 19'5 x 14'5 cms. 


\section{B.- CATECISMO CHINO, HACIA 1925}

La segunda obra que vamos a estudiar es un Catecismo Chino con láminas policromadas, impreso hacia el año $1925^{69}$

\section{Datos generales}

Este catecismo se encontraba dentro de los fondos del Museo Oriental. Creemos que ha llegado aquí con ocasión de la Exposición Vaticana de Misiones del año 1925. Es muy probable que haya venido desde Shanghai, el principal centro impresor de China y donde los agustinos tenían, desde finales del siglo XIX, la casa procuración. Desde esta sede se dirigía la administración de la misión y allí los misioneros comenzaban el aprendizaje de la lengua china. En esta casa de Shanghai -gracias principalmente a la iniciativa del P. Gaudencio Castrillo-, se formó una biblioteca importante, donde, además de obras de filosofía y teología existían libros de otras disciplinas como literatura, viajes, geografía, arte, historia, religiones, mitología, etc., muchas de ellas relacionadas con el mundo oriental en general y con China en particular ${ }^{70}$.

El presente catecismo está formado por un total de 40 páginas impresas al estilo chino en forma de acordeón. Veinte de ellas son láminas litográficas policromadas, y las otras veinte, colocadas al frente, son una explicación en chino del tema de cada una de las láminas.

Las dimensiones totales de las páginas es de $322^{\prime} 5$ x $22^{\prime} 5 \mathrm{cms}$, y el diseño interior de $28^{\prime} 5$ x $20^{\prime} 5 \mathrm{cms}$.

Lleva como número de catálogo el 48.388 y en la lámina del infierno tiene impreso el sello de la biblioteca "Agustinos Filipinos, Valladolid".

Las veinte láminas en color tienen la siguiente temática: la primera se refiere a la Santísima Trinidad, tres más son de episodios del Antiguo Testamento, nueve nos presentan episodios de la vida de Jesús del Nuevo Testamento, una se refiere a la iglesia y las seis últimas están dedicadas a los llamados "Novísimos": muerte del justo y el pecador, juicio, infierno, y gloria.

Las trece primeras están inspiradas en grabados europeos, como veremos con más detalle, y siguen el estilo occidental. Algunos de ellos están ins-

\footnotetext{
${ }^{69}$ Catecismo chino con láminas policromadas, Shanghai, hacia 1925.

${ }^{70}$ Sierra de la Calle, Blas, China 1793. La Embajada de Lord Macartney, Edición Caja España-Museo Oriental, Valladolid 2006, pp. 67-69.
} 
pirados -incluso reproducidos casi fielmente- en la obra "Gran Colección de láminas del Antiguo y Nuevo Testamento", realizada por el eminente artista Julius Schnorr von Carolsfeld. Las siete últimas han salido indudablemente, de la mano de un artista chino y los rasgos orientales se reflejan en los rostros de la mayoría de los personajes representados.

\section{Descripción de los grabados}

Pasamos a continuación a estudiar una tras otra las distintas imágenes de la obra.

\section{1.- La Santísima Trinidad}

Esta litografía en color muestra la concepción cristiana de Dios uno y trino. La triada divina aparece enmarcada dentro de una estructura oval, formada en la parte inferior por nubes y, en la superior, por una franja de cabezas de ángeles alados.

El Padre y el Hijo son representados sentados en un trono. El primero, con barba blanca y corona en la cabeza, va vestido de una túnica blanca y un manto morado. Sostiene un cetro en su mano izquierda y una esfera del mundo en su mano derecha, para indicar su condición de creador del mundo.

El segundo, Jesús, con barba negra y corona, va vestido con una túnica roja y un manto azul. Lleva en sus manos la herida de los clavos, en alusión a la crucifixión. Con su mano izquierda indica su corazón ardiente de amor, mientras que con la mano derecha sostiene la cruz, símbolo de su misión redentora.

En la parte superior, entre el Padre y el Hijo, se encuentra representado el Espíritu Santo, en forma de paloma blanca. Está enmarcado en el interior de una flor de loto amarilla. En los ángulos superiores se contemplan las nubes y las estrellas.

Esta representación de la Santísima Trinidad ha tomado como modelo el grabado n 9 del "Catecismo en estampas" obra de P. Grenier, publicada en París en 190971. (Ilustraciones 28 y 29)

\section{2.- Adán y Eva en el Paraíso (Gen 2, 5-25)}

El grabado en color nos muestra la vida idílica de Adán y Eva en el paraíso terrenal. En la parte superior, aparece por encima de las nubes, la fi-

\footnotetext{
${ }^{71}$ Maison de la Bonne Presse (Edi.), Catecismo en estampas, Casa de la Buena Prensa, París 1909.
} 
gura del Padre Eterno, con los brazos abiertos contemplando su creación. Tiene el pelo y la barba blancas y está vestido con una túnica verde y un manto rojo. A uno y otro lado le acompañan una triada de ángeles y las representaciones del sol, la luna y las estrellas.

En la parte inferior ocupan el lugar central las figuras de Adán y Eva, que están desnudas y en actitud reverente mirando hacia lo alto. La parte inferior de su cuerpo está cubierta por unos arbustos. Entre ellos, a orillas de un lago, está colocado el árbol con el fruto prohibido, en el que está enroscada una serpiente verde. Entre varios árboles frondosos pueden observarse distintos animales: jirafa, caballo, león, buey, cordero, serpiente, conejos, garzas, ciervos, pavo real.

La viveza de los colores hace a la obra muy atractiva. Está inspirada en modelos europeos, probablemente de escuela italiana. (Ilustración 30)

\section{3.- Expulsión de Adán y Eva del Paraíso y promesa del redentor (Gen 3, 1-} 24)

El paraíso es mostrado con varios árboles verdes y flores de colores rosa, rojo y amarillo. Dentro de él, un ángel joven, con una espada de fuego en la mano derecha, señala, con la mano izquierda la puerta de salida del paraíso a Adán y Eva. Ellos caminan hacia el exterior acongojados, como puede verse por la expresión adolorada de Eva y la postura de Adán, que esconde el rostro entre las manos. Ambos van descalzos, vestidos con trajes de pieles. A sus pies puede verse la serpiente tentadora.

En el ángulo superior de la imagen está representada encima de una nube y una media luna, la Virgen María con el Niño Jesús en brazos, como preanuncio de la futura salvación. Madre e Hijo están rodeados de una aureola de luz para indicar su santidad.

Se trata de una interpretación simplificada y policromada de la obra "Salida del Paraíso" pintada por Julius Schnorr von Carolsfeld, entre 1852 y 1860, grabada por Steinbrecher, en el no. 10 de la "Gran colección de láminas del Antiguo y Nuevo Testamento"72. (Ilustraciones 31 y 32)

4.- Moisés recibe las tablas de los Diez Mandamientos (Ex 19, 16-25, 20, 1-

21)

En esta imagen Dios se muestra como un anciano con barba y pelo blanco. Viste una túnica naranja y un manto rojo. De Él brota un resplan-

${ }^{72}$ SchnORR VON CAROLSFELD, Julius, Gran colección de láminas, grabado n ${ }^{\circ} .10$. 
dor de rayos amarillos. Le rodean seis ángeles tocando la trompeta. Todo ello está encerrado dentro de una nube blanca. Él sostiene en sus manos las tablas del Decálogo, donde están escritos de derecha a izquierda, en números romanos los Diez Mandamientos. Está haciendo entrega de ellos a Moisés, vestido con una túnica morada y un manto azul. Éste las recibe arrodillado en actitud sumisa, en la cima del monte a donde ha subido para encontrarse con su Dios.

Esta cromolitografía sigue el modelo de la obra "Moisés recibe las tablas de la Ley” pintada por Julius Schnorr von Carolsfeld, entre 1852 y 1860, grabada por J. Jungtow, en el $\mathrm{n}^{\circ} .54$ de la "Gran colección de láminas del Antiguo y Nuevo Testamento"73. (Ilustraciones 33 y 34)

\section{5.- Natividad de Jesús y adoración de los pastores (Le 2, 1-20)}

Este colorista grabado nos muestra a Jesús recién nacido en la cuna, bajo los cuidados de su madre María, que le está cubriendo con un manto blanco y la atenta mirada de José, que está a sus espaldas. Al lado, aparecen las cabezas del buey y la mula. Se encuentran bajo un cobertizo de madera construido al lado de la gruta. Frente a ellos, un grupo de cuatro pastores que han venido a adorarlo y lo contemplan admirados. Han traído como regalo un cordero blanco que está en el suelo, con las patas atadas. En el ángulo superior derecho resplandece en el cielo la figura de un ángel que está dando el anuncio del nacimiento de Jesús a algunos pastores, que están al cuidado de su rebaño de ovejas.

Esta cromolitografía es una reproducción parcial de la obra "Nacimiento de Cristo" pintada por Julius Schnorr von Carolsfeld, entre 1852 y 1860 , grabada por Gaber, en el n'. 158 de la "Gran colección de láminas del Antiguo y Nuevo Testamento" "74. (Ilustraciones 35 y 36)

\section{6.- María y José encuentran al Niño en el templo de Jerusalén (Lc 2, 41-50)}

Un Jesús adolescente está sentado en la cátedra. Tiene a su lado una pequeña estantería de libros. Discute con tres doctores de la ley sentados y un tercero de pie. Todos ellos llevan vestimentas muy coloristas (verde, roja, amarilla, azul,...). Uno se está dirigiendo a Jesús, mientras, con una mano, está indicando una cita en el Libro de la Ley; otro, está todo pensa-

\footnotetext{
${ }^{73}$ SCHNORR VON CAROLSFELD, Julius, Gran colección de láminas, grabado no ${ }^{\circ} 54$.

${ }^{74}$ SCHNORR VON CAROLSFELD, Julius, Gran colección de láminas, grabado n ${ }^{\circ} .158$.
} 
tivo leyendo un texto; el tercero está observándole con atención. Mientras Jesús está concentrado en este diálogo, por el fondo, aparecen las figuras de María y José que se alegran al encontrarlo y parece que quieren correr hacia él.

Esta cromolitografía es una copia parcial de la obra "Jesús disputando en el templo con los doctores" pintada por Julius Schnorr von Carolsfeld, entre 1852 y 1860, publicada como n'. 165 de la "Gran colección de láminas del Antiguo y Nuevo Testamento"75. (Ilustraciones 37 y 38)

\section{7.- Jesús modelo de obediencia y piedad filial (Le 2, 51)}

En Lc 2, 51 se nos dice que después del episodio del templo de Jerusalén, Jesús bajó con María y José a Nazaret y les estaba sujeto.

Este grabado lleno de color es una reconstrucción de la vida de la Sagrada Familia en Nazaret. En esta obra se quiere resaltar uno de los valores más importantes de la cultura china: la piedad filial. Se trata no solo de obediencia, sino también de respeto y veneración hacia los padres y los ancianos, en este caso hacia María y José y hacia Joaquín y Ana, los padres de la Virgen. Todos ellos están contemplando a un Niño Jesús que está trabajando en la carpintería, siguiendo las instrucciones de José el carpintero, que le observa. Todos están sentados, a excepción de José, que está arrodillado, atento a cómo Jesús maneja la sierra. En la pared de la casa se abre un gran ventanal por el que pueden verse árboles de coco y palmeras, y, al fondo, las montañas y un castillo ${ }^{76}$. (Ilustración 39)

\section{8.- El Sermón de la Montaña (Mt 5, 1-11)}

Este grabado nos muestra a Jesús con los brazos abiertos, predicando desde lo alto de un monte. Tiene a su lado, de pie, a sus discípulos, tres a cada lado. Detrás de Él se ven a algunas personas que escuchan con atención. Delante, en primer plano, hay dos grupos de personas. A la izquierda cuatro mujeres recostadas en el suelo que aparentan cansancio. A la derecha cuatro hombres sentados. Dos parecen escuchar a Jesús con atención y le están mirando. Otro - probablemente un pastor, pues lleva un cayado en la mano-, está concentrado mirando al suelo mientras escucha. El cuarto,

\footnotetext{
${ }^{75}$ SchnORR VON CAROLSFEld, Julius, Gran colección de láminas, grabado n ${ }^{\circ} .165$.

${ }^{76}$ Para comprender este grabado hay que tener en cuenta la doctrina confuciana sobre la piedad filial y los diseños cómo ésta es representada. Vease: Ershisi XIAO, 24 Filial Pieties, Beijing 1993. Facsimil de una edición Ming.
} 
parece un soldado, pues lleva un puñal o una espada en la mano izquierda. Está pensativo con la cabeza apoyada en su mano.

Esta cromolitografía es una copia de la obra "El Sermón de la Montaña" pintada por Julius Schnorr von Carolsfeld, entre 1852 y 1860, publicada como n". 178 de la "Gran colección de láminas del Antiguo y Nuevo Testamento" 77 . (Ilustraciones 40 y 41)

\section{9.- La resurrección de Lázaro (Jn 11, 1-43)}

Jesús, acompañado de sus discípulos y de Marta y María se ha acercado al lugar donde estaba enterrado Lázaro. Él está de pie, vestido con una túnica roja y un manto azul. Una vez que ha hecho que abran la tumba, está ordenando a Lázaro: “SSal fuera!”.

Frente a Él vemos a Lázaro envuelto en vendas que está saliendo de la tumba. Todos miran sorprendidos. Uno de los que ha retirado la piedra del sepulcro se tapa la nariz, para evitar el mal olor. Las hermanas de Lázaro, Marta y María, están arrodilladas junto a Jesús en actitud orante, con las manos juntas. Dos de los discípulos y una mujer miran con sorpresa lo sucedido

Esta cromolitografía es la reproducción parcial de la obra "Resurrección de Lázaro" pintada por Julius Schnorr von Carolsfeld, entre 1852 y 1860, publicada como no. 194 de la "Gran colección de láminas del Antiguo y Nuevo Testamento" ${ }^{\text {". }}$. (Ilustraciones 42 y 43)

\section{0.- La oración del Huerto (Lc 22, 39-46)}

El grabado nos muestra a Jesús, fuera de la ciudad, en el Monte de los Olivos. Está de rodillas orando a Dios Padre, para que pase de él esta hora. Frente a él aparece un ángel entre nubes, que le está dando una cruz. En la parte baja del diseño -vestidos con vivos colores rojo, azul, amarillo, morado, verde y rosa-, están tres de los apóstoles, Pedro, Santiago y Juan. Vencidos por el cansancio, están durmiendo. Pedro tiene entre sus manos una espada. Al fondo del diseño, por la parte derecha, se ve entrar por la puerta un grupo de soldados con antorchas encendidas que viene dispuesto a capturar a Jesús.

En la esquina inferior izquierda se ven las iniciales "TW" que podrían referirse al grabador, que realizó la obra. Esta cromolitografía es la repro-

\footnotetext{
${ }^{77}$ SCHNORR VON CAROLSFELD, Julius, Gran colección de láminas, grabado n ${ }^{\circ} .178$.

${ }^{78}$ SCHNORR VON CAROLSFELD, Julius, Gran colección de láminas, grabado n ${ }^{\circ} .194$.
} 
ducción bastante fiel del grabado "Jesús en el Huerto de Getsemaní" pintado por Julius Schnorr von Carolsfeld, entre 1852 y 1860, publicado como $\mathrm{n}^{\circ}$. 200 de la "Gran colección de láminas del Antiguo y Nuevo Testamento"

\section{(Ilustraciones 44 y 45)}

\section{1.- Jesús con la cruz a cuestas camino del calvario (Lc 23, 26-28)}

La escena se desarrolla fuera de las murallas de Jerusalén. La arquitectura de las torres parece estar inspirada en una ciudad italiana. Jesús -vestido con una túnica roja y con la corona de espinas a la cabeza-, ha caído al suelo, vencido por el peso de la cruz que lleva a hombros. Un soldado intenta coger la cruz para que él pueda levantarse. En este momento se le acerca su madre llorando, que le tiende las manos. Jesús la mira compasivo. Acompañan a María otras tres mujeres -las Tres Marías-, y un anciano, probablemente, José de Arimatea.

A pesar del dramatismo de la escena, el fuerte colorido de la vestimenta de los personajes da a la obra un tono alegre. Este, como los anteriores temas, está inspirado en obras de arte europeo. Concretamente, esta cromolitografía es una reproducción parcial simplificada de la famosa obra de Rafael Sanzio "Caída en el camino del calvario", conocida también como "El Pasmo de Sicilia”. Esta pintura, realizada entre 1515-1516, se encuentra en el Museo del Prado de Madrid. El artista chino probablemente se basó en el grabado de dicha obra de Domenico Cunego realizado al aguafuerte y buril sobre papel verjurado en $1781^{80}$. (Ilustraciones 46 y 47)

\section{2.- La crucifixión de Jesús (Lc 23, 33-46)}

El grabado muestra a Jesús crucificado y con la cabeza ya inclinada hacia abajo, señal de que ya ha fallecido. De su costado, así como de los pies y las manos, brota la sangre. Su cabeza está rodeada de un aura de resplandor situado debajo del letrero INRI (Jesús Nazareno Rey de los Judíos). A los pies de la cruz está su madre, que, llorando, tiene entre sus brazos la cruz y los pies de su hijo muerto. A su lado, otras dos mujeres compungidas; y, postrada en tierra, la Magdalena, son su larga cabellera. A un lado, con las manos en actitud orante, vemos al Discípulo Amado, Juan, que

${ }^{79}$ SCHNORR VON CAROLSFELD, Julius, Gran colección de láminas, grabado no ${ }^{\circ} 200$.

${ }^{80}$ Ver más información sobe esta famosa pintura y el grabado correspondiente en la página web del Museo del Prado: https://www.museodelprado.es/coleccion/obra-de-arte/caidaen-el-monte-calvario/870c8293-1691-4a90-88ff-b554a2bc3fe8 
mira compasivo al Crucificado, su maestro. Por detrás, se ve una gran multitud de gente y soldados con lanzas que, -una vez terminado el espectáculo-, parecen estar retirándose.

Esta cromolitografía es la reproducción bastante fiel -con algunas acomodaciones-, del grabado “Jesús en la cruz” pintado por Julius Schnorr von Carolsfeld, entre 1852 y 1860, publicado como n'. 208 de la "Gran colección de láminas del Antiguo y Nuevo Testamento"81. (Ilustraciones 48 y 49)

\section{3.- La Resurrección de Jesús (Mc 16,9)}

El grabado nos muestra a Jesús con una túnica roja y un estandarte en la mano derecha, que está saliendo del sepulcro. A su alrededor, se ve un gran resplandor del luz entre nubes. Al lado un ángel vestido de blanco y amarillo, que ha retirado la losa del sepulcro. En primer plano dos soldados -uno con la espada en la mano y otro en la vaina-, parecen estar despertándose, sobresaltados ante tal acontecimiento: la resurrección de un muerto.

Esta cromolitografía es la reproducción parcial del grabado "Resurrección de Jesús” pintado por Julius Schnorr von Carolsfeld, entre 1852 y 1860 , y grabado por Jungtow, publicado como n". 210 de la "Gran colección de láminas del Antiguo y Nuevo Testamento”. (Ilustraciones 50 y 51)

\section{4.- La Iglesia, una, santa, católica y apostólica}

En el centro -bajo un dosel con las figura del Espíritu Santo en forma de paloma-, se encuentra sentado el Papa. Lleva en su cabeza la tiara, en la mano izquierda un báculo con triple cruz, mientras con su mano derecha indica el símbolo de la Trinidad. A ambos lados están -báculo o libro en mano-, obispos y patriarcas. En primer plano, a los pies de la escalera, arrodillados, vemos una representación de los hombres de distintas razas: negros, europeos, chinos, indios, y, en medio, dos niños arrodillados en actitud orante. En la parte superior hay dos recuadros. En uno se muestra a Cristo entregando las llaves a san Pedro y, en el otro, pidiéndole que se haga cargo de su rebaño.

Esta obra parece haber salido de la mano de un artista chino, si tenemos en cuenta los rasgos de los ojos de los personajes y la expresión de sus rostros todos ellos "achinados". (Ilustración 52)

\footnotetext{
${ }^{81}$ SCHNORR VON CAROLSFELD, Julius, Gran colección de láminas, grabado n ${ }^{\circ} .208$.
} 


\section{5.- La gloria del cielo}

La gloria del cielo tiene como centro la Trinidad, representada en el interior de un círculo rodeado de ángeles en la parte superior. Al igual que en el primer diseño de esta obra, el Padre se caracteriza por la esfera del mundo, el Hijo por la cruz y el Espíritu Santo se representa en forma de paloma. Debajo de ellos está la Virgen María entre los arcángeles san Gabriel y san Miguel. A uno y otro lado se encuentran san José, san Juan Bautista y los apóstoles, entre ellos san Pedro y san Pablo. En la parte inferior, a nuestra izquierda, están un conjunto de santos, vírgenes y mártires, entre ellos sta. Isabel de Hungría, sta. Inés y sta. Cecilia. En la parte derecha, vemos a varios santos, papas, obispos, monjes, mártires, reyes,... Dos de ellos están caracterizados con vestimenta y gorro chino.

Al igual que la cromolitografía anterior esta ha salido también de la mano de un artista chino. (Ilustración 53)

\section{6.- La muerte del justo}

En este grabado se nos muestra la muerte de un anciano. El moribundo está recostado en una cama creada para la ocasión, poniendo un tablero sobre dos mesas. A su cabecera, está un ángel que le invita a mirar al cielo. A sus pies, están sus hijos -marido y mujer-, y sus nietos. A lado derecho el sacerdote y el acólito. El primero, con roquete y estola, está ungiéndole las manos. El acólito, en una mano sostiene un crucifijo y, en la otra, los santos óleos. Detrás, hay un altar, cubierto con un mantel blanco. Sobre él está una imagen de la Virgen María y el Niño Jesús entre dos velas. En la parte superior,-entre nubes, dispuestos a recibir al moribundo-, las imágenes de Jesús, la Virgen y san José. En el ángulo inferior, a la derecha -en medio de las llamas-, un diablo negro que huye, constatando que en esta ocasión no tiene nada que hacer.

Tanto el diseño del moribundo como el de los personajes nos revela que se trata de una obra de artista chino. De todos modos parece estar inspirada en el grabado $\mathrm{n}^{\circ} 57$, realizado por P. Grenier, para la obra "Catecismo en estampas”, publicada en París en $1909^{82}$. (Ilustración 54)

\section{7.- Llamamiento al juicio final}

En la parte superior, al centro, aparece la figura de Cristo Juez Universal. Está vestido con una túnica roja y el manto azul, con la cabeza cu-

${ }^{82}$ Maison de la Bonne Presse, Catecismo en estampas, Casa de la Buena Prensa, París $1909, \mathrm{n}^{\circ} 57$. 
bierta por una corona. Tiene a sus espaldas la cruz y, a sus pies, el globo del universo poblado de estrellas. Todo alrededor, en semicírculo, lleva una corte de cabezas de ángeles. A su derecha, tiene la Virgen María Reina y, a su izquierda, el arcángel san Miguel con un libro abierto con caracteres chinos. A uno y otro lado -sobre una nube blanca-, están san Pedro, san Pablo, Apóstoles y multitud de santos. En la parte central, un ángel con túnica roja está tocando la trompeta y convocando a toda la humanidad al juicio final. En la parte inferior se ven a todos los muertos saliendo de los sepulcros. A un lado se observan a los ángeles que están llevando a los santos justos -entre ellos tres mandarines chinos-, hacia el cielo. A otro lado una legión de diablos -representados en formas grotescas-, están conduciendo a los condenados a un infierno de fuego.

También esta obra ha salido, indudablemente, de la mano de un artista chino, como revelan la abundancia de ideogramas chinos que aparecen en diversos lugares. (Ilustración 55)

\section{8.- El purgatorio}

El grabado está estructurado en tres partes. En la parte superior, entre nubes, está la Virgen María con el Niño Jesús en brazos, rodeada de dos ángeles, que dan la bienvenida al cielo a un mandarín chino. En la parte central, un sacerdote vestido con ornamentos litúrgicos chinos está celebrando una misa, a la que asiste un grupo de gente. A cada uno de los lados, un ángel acompaña a un mandarín hacia el cielo. En la parte inferior vemos tres ángeles. Uno, está rezando y, los otros dos, están derramando sobre las almas del purgatorio un cáliz con la sangre de Cristo. Por debajo, puede verse toda una multitud de almas del purgatorio, que están purificándose en medio de las llamas.

También esta obra -como podemos deducir, por las vestimentas y las expresiones de los rostros-, ha salido de la mano de un artista chino. (Ilustración 56)

\section{9.- Muerte del pecador impenitente}

El moribundo es un chino, acostado al lado de una mesita con una pipa de opio. Tiene el rostro desesperado. A sus pies está la mujer y dos niños en lágrimas. A un lado aparece un ángel con un libro en la mano, desconsolado porque se ve impotente. El moribundo está rodeado de varios diablos de diversos colores y un dragón que sale del fuego y echa fuego por sus fauces. En la parte superior vemos dos ángeles. Uno muestra una lista en blanco, 
indicando la falta de obras buenas. El otro, san Miguel -con una balanza en una mano y una espada en la otra-, está rechazando a un demonio que transporta, probablemente, lo que sería el espíritu o alma del moribundo. En medio de la nube, vemos a Cristo sentado en el trono, que, ante el rechazo del moribundo de reconocerlo, se ve impotente para salvarlo.

Nadie que no sea chino podría representar esta escena como aquí la encontramos. La actitud de todos los protagonistas, contrasta, grandemente con la que hemos visto anteriormente sobre la muerte del justo. (Ilustración 57)

\section{0.- Las penas del infierno}

El artista chino muestra los castigos del infierno, que se asemejan mucho a las representaciones occidentales sobre este mismo tema.

En la parte superior vemos a cinco mujeres llorando desconsoladamente, en medio de las llamas. Una de ellas está maniatada y, a la otra, le está atacando un diablo horrible de color azul. En la zona central, tres hombres desnudos, entre las llamas, se están arañando y peleando entre ellos. A un lado, un demonio serpiente, está mordiendo la cabeza de una mujer. En el lado derecho, otra serpiente ha rodeado el cuerpo de otro condenado y lo está estrangulando, al mismo tiempo que le muerde en la boca. En la zona inferior vemos los rostros aterrorizados, en medio de las llamas, de otros siete condenados. Los de la izquierda están siendo atacados por una serpiente con alas. El del medio está siendo mordido por un demonio negro con cuernos. Otro de la derecha está bebiendo en un cáliz que le fuerza a tomar un horrible demonio negro y rojo con cuernos. (Ilustración 58)

\section{C.- LA HISTORIA MÁS FAMOSA, 1950}

La tercera obra que vamos a estudiar es una vida de Jesús en colores, impresa en Shanghai en el año 1950

\section{Datos generales}

El título chino de la obra es "La Historia más famosa" y trata de la vida de Jesús. La primera edición se realizó en septiembre de 1950, en Shanghai. El autor de los dibujos es Chen Guanyi, mientras que el autor de los textos es Chen Wanlin. Consta como editor Tian Wanglin y los amigos 
de la religión católica. Fue editado por la Asociación de la promoción y ayuda de asuntos de la religión católica y distribuido por la misma asociación que tenía su domicilio en el no 197 de la Calle Yueyang de Shanghai ${ }^{83}$.

En la portada el artista Chen Guanyi muestra a una madre y cuatro niños sosteniendo un libro, precisamente, esta vida de Jesús "La Historia más famosa”. A su lado, en el ángulo superior derecho, observan el libro, su marido y sus padres. Es decir, el artista quiere mostrarnos cómo la vida de Jesús era centro de atención -y es de suponer que también de la vida-, para tres generaciones de chinos: abuelos, padres y nietos. (Ilustración 59)

La obra está dividida en dos tomos de 13 x $10 \mathrm{cms}$. El primero de ellos, está en los fondos de la Biblioteca del Estudio Teológico Agustiniano con el número antiguo 146.397 y el actual $\mathrm{CH}$ 7. El segundo volumen se encontraba, hasta ahora, en los fondos del Museo Oriental. Los dos tomos llevan una paginación continuada desde la página 1 hasta la 279. El primero lleva una paginación progresiva desde la p. 1 a la 144. En la primera se representa la creación salvaje, mientras que, en la 144 se termina con los preparativos de la Pascua o Última Cena de Jesús. El segundo tomo comienza en la página 145 representando el lavatorio de los pies antes de la Última Cena, y concluye en la 279 , con un texto sobre los sacramentos y un diseño de un sacerdote predicando a un niño.

Cada página lleva un pequeño texto chino en la parte derecha del diseño y otro texto en la parte superior que hacen alusión a la escena representada. La dimensión de las cromolitografías es de 10 x 7’5 cms.

La temática representada es fundamentalmente la vida de Jesús, desde su nacimiento hasta su ascensión al cielo y, brevemente, los inicios de la vida de la iglesia primitiva y las persecuciones. Sintéticamente, algunos de las cromolitografías representan varios de los aspectos histórico culturales promovidos por la religión católica en China. Concluye dedicando un diseño a cada uno de los siete sacramentos.

El autor de los textos, Chen Wanlin, a la hora de presentar la historia de Jesús, usa textos de los cuatro evangelistas: Mateo, Marcos, Lucas y Juan, así como los Hechos de los Apóstoles, como veremos. Pero más que copiar textualmente la historia de Jesús, tal y como nos la cuentan los evangelios,

${ }^{83}$ Chen Wanlin. La Historia más famosa, Tian Wanglin (Edit.) Shanghai 1950. Agradecemos a la investigadora Longling Yu, Presidenta de CCACO (Centro de Cultura y Arte China Occidente) la traducción de estos datos de la portada, así como la traducción de los textos de algunos otros diseños de esta obra, que nos han ayudado para su identificación. 
por lo general, se limita a destacar algunos aspectos, y hacer breves comentarios explicativos.

El autor de las imágenes es el artista chino Chen Guanyi. Él muestra de forma extraordinariamente atractiva toda la historia de Jesús. No tenemos datos sobre él, pero, sin duda alguna, era un ilustrador punta en los talleres de impresión de Shanghai en la primera mitad del siglo XX. Él demuestra un buen conocimiento de la cultura de la época y de las costumbres romanas y judías, como puede deducirse de la vestimenta de los personajes y de la ambientación. Se ve en el trabajo que posee un perfecto dominio del diseño y la composición, así como de la combinación del color. Aunque no deja de quedar claro que está profundamente enraizado en la tradición pictórica china, como puede constatarse, sobre todo, a la hora de representar paisajes y montañas. El colorido y la fuerza y expresividad de los diseños, hace que no sea necesario entender el chino, para poder comprender de qué trata la historia. Salvo en raros casos, los dibujos hablan por sí mismos.

Dada la diferencia de estilo pictórico, pensamos que las últimas siete imágenes, que hacen referencia a los siete sacramentos, no son obra del artista Chen Wanlin, sino que han salido de la mano de otro diseñador menos creativo y experto.

\section{Descripción de los grabados}

Pasamos a continuación a describir brevemente cada uno de estas cromolitografías. Los títulos que hemos dado a cada una no pretenden ser la traducción del texto chino, sino que corresponden a la idea principal del dibujo, según nuestra percepción personal. A cada uno de los grabados hemos intentado emparejarle el texto evangélico al que se hace referencia.

\section{1.- La ley de la jungla}

Este primer grabado muestra una naturaleza exuberante en la que los animales sobreviven matándose unos a otros. Un tigre está atrapando con sus garras a un cérvido, que intentaba escapar al galope. A su vez, una serpiente intenta capturar un pájaro en vuelo.

\section{2.- Un mundo en guerra}

Jinetes a caballo y carros de guerra tirados por caballos se persiguen en medio de una batalla. Están atacando con espadas, lanzas y flechas. En primer plano, yacen en el suelo un jinete y un caballo muertos. 


\section{3.- El egoísmo de los ricos}

En el interior de una casa, un rico está banqueteando opíparamente, en una mesa con abundante comida y bebida. Le atienden dos camareros. Uno le está sirviendo vino y el otro le trae un gran recipiente de comida. En primer plano, un tercer sirviente, con látigo en la mano, trata de expulsar a un mendigo harapiento que está pidiendo limosna.

\section{4.- Los chinos adorando el dinero}

Al centro de un gran templo se encuentra un altar en el que hay expuestos lingotes de oro gigantes que tienen la típica forma de los "yuanbao" o lingotes de plata chinos. Dentro del templo se encuentra una multitud de chinos que están arrodillados en el suelo, adorando al "Dios dinero" ${ }^{\prime 4}$. (Ilustración 60)

\section{5.- Comienzo de una nueva era}

Un rayo de luz divide el cielo en diagonal y anuncia una nueva era. Por debajo, bajo un cielo oscuro -entre altas montañas, a orillas de un puerto con embarcaciones de vela-, se ve acercarse un ejército con lanzas y banderas. En la otra mitad, un cielo azul con la luna y las estrellas preanuncia la llegada de una nueva era.

\section{6.- La tierra de promisión}

El globo terrestre está rodeado por un cielo oscuro. En él se indican los territorios de Asia, parte de África y parte de Europa. Una flecha señala la situación donde se encuentra Palestina.

\section{7.- Todo comienza en Nazaret}

En una visión aérea del territorio de Palestina, se indica a la izquierda el mar Mediterráneo; a la derecha el lago de Tiberíades y el río Jordán y, en medio, diversas ciudades. Una flecha en la parte superior, señala la ciudad de Nazaret.

${ }^{84}$ Thierry, Francois, Monnaies de Chine, Bibliothèque Nationale, Paris 1992, pp. 68-71; Xinhua Publishing House, A History of Chinese Currency $\left(16^{\text {th }}\right.$ Century BC-20 $0^{\text {th }}$ Century $A D)$ Hong Kong 1983, p. 35. 


\section{8.- La villa de Nazaret}

Nazaret es presentada como una pequeña ciudad entre montañas, por donde pasa un riachuelo, en el que una mujer está recogiendo agua. A lo largo de la calle se ven pequeñas casas de piedra, rodeadas de verdes palmeras. En primer plano podemos ver una carpintería, con algunos troncos arrimados a la pared. Dentro, se ve trabajando a dos personas. El primero de ellos -que está serrando un tronco-, es José de Nazaret.

\section{9.- La joven María cosiendo}

En el interior de una casa vemos a María de Nazaret. Tiene el rostro joven y los cabellos largos, de color negro, que le bajan hasta el pecho. Cubre su cabeza con un pañuelo blanco. Está vestida con una túnica rosa y un manto verde. Está cosiendo. Tiene entre sus manos una tela amarilla y una aguja.

\section{0.- La Anunciación del ángel a María (Lc 1, 26-38)}

En medio de una habitación en penumbra, un rayo de luz amarilla entra por el ángulo izquierdo. Un joven ángel, con grandes alas, vestido de blanco, está haciendo un anuncio a María. Esta se encuentra sentada, al lado de una alacena con recipientes de cocina, y con las manos juntas. Mira al ángel sorprendida y escucha atenta su propuesta. (Ilustración 61)

\section{1.- Las reflexiones de José}

José es presentado como un hombre maduro, calvo, con barba negra. Está sentado en su carpintería, con un tablón a su espalda y, de frente, el banco de trabajo y la sierra. Está en actitud pensativa, apoyando su mentón sobre el brazo, que a su vez reposa sobre su rodilla. Le han anunciado que María, su prometida, espera un hijo. Pero, este no es suyo. ¿Qué hacer?

\section{2.- El anuncio del ángel a José en sueños (Mt 1, 18-25)}

José está acostado en su lecho, con las sábanas blancas y una colcha verde. Mientras duerme, un ángel se le aparece y le revela cuál es el origen del niño que espera María: “José, Hijo de David, no temas tomar contigo a María, tu mujer, porque lo engendrado en ella es del Espíritu Santo” (Mt 1, 20-21).

\section{3.- El edicto de César Augusto (Lc 2, 1-3)}

En uno de los muros de la ciudad está pegado un edicto de César Augusto. José, junto con otras personas, están leyéndolo atentamente. En él se ordenaba que todo el mundo fuese a empadronarse a su ciudad de origen. 


\section{4.- José comunica a María que deben viajar a Belén}

Dentro de la casa -en cuya pared hay colgada una sierra-, José le está comunicando a María la orden del edicto. Deben ponerse de viaje e ir a Belén a empadronarse. María escucha con atención y, con un gesto de la mano, parece objetar, indicando que se encuentra en avanzado estado de gestación.

\section{5.- María y José camino de Belén (Lc 2, 4-5)}

"Subió también José, desde Galilea, de la ciudad de Nazaret a Judea, a la ciudad de David, que se llama Belén, por ser él de la casa y familia de David, para empadronarse con María, su esposa, que estaba encinta (Lc 2, 4-5).

En medio de un paisaje nevado contemplamos a José conduciendo el borriquillo sobre el que va sentada María. Están leyendo una indicación que les muestra el camino a seguir. (Ilustración 62)

\section{6.- María y José buscan posada (Lc 2,7)}

En medio de una noche gélida, sin estrellas, María y José buscan posada. José va a pie, María sobre la cabalgadura. Se abre una puerta y aparecen los posaderos con una vela en la mano, pero,... "no tenían sitio en la posada” (Lc 2,7).

\section{7.- María y José se cobijan en una cueva}

Fuera de la ciudad, María y José encuentran una cueva. José con una expresión bastante angustiada, le está indicando a María que no tienen más opciones. María escucha atentamente la propuesta y la acepta.

\section{8.- Nacimiento de Jesús (Lc 2 6-7)}

“... y dio a luz a su hijo primogénito, le envolvió en pañales y le acostó en un pesebre" (Lc 2, 6-7).

Una vez que Jesús ha nacido, su madre María lo sostiene entre sus brazos. José le está acercando una cuna con paja para que coloque allí al niño. A la puerta de la cueva está el asno y, en primer plano, el buey, que aquí es un "carabao" o búfalo de agua, mamífero típico del Oriente. (Ilustración 63)

\section{9.- El anuncio a los pastores (Lc 2, 8-12)}

En medio de la noche invernal, con el suelo cubierto de nieve, dos grupos de pastores se están calentando en las hogueras. Un ángel del Señor se 
apareció primero a unos y después a los otros y les anuncia que "en la ciudad de David ha nacido un Salvador, que es Cristo el Señor” (Lc 2,11).

\section{0.- Adoración de los pastores (Lc 2, 15-18)}

Tras el anuncio del ángel, los pastores "fueron a toda prisa y encontraron a María, a José y al niño acostado en el pesebre" (Lc 2,16).

La cueva se ha llenado con la presencia de los pastores que adoran al niño Jesús, María está a un lado arrodillada. En primer plano, José de pie y, al lado izquierdo, el buey-carabao y el asno.

\section{1.- Los magos contemplan una nueva estrella}

Tres magos, desde la terraza de un palacio, están contemplando la noche estrellada y les sorprende la aparición de una nueva estrella, que presagiaba el nacimiento de alguien importante. Están concentrados estudiando el fenómeno sin preocuparse de un sirviente que les ha traído una bandeja con frutas.

\section{2.- Los magos guiados hasta Belén (Mt 2, 1-11)}

"Los magos se pusieron de viaje (...) La estrella que habían visto en Oriente, iba delante de ellos, hasta que llegó y se detuvo encima del lugar donde estaba el niño" (Lc 2,9).

Los tres magos montados en camellos llegan a Belén guiados por la estrella, que se ha detenido encima de una casa de piedra.

\section{3.- La adoración de los magos (Mt 2,11)}

Los magos "entraron en la casa, vieron al niño con María su madre y, postrándose le adoraron; abrieron luego sus cofres y le ofrecieron dones de oro, incienso y mirra" (Mt 2,11).

El diseño refleja este momento, en el que los magos están ofreciendo sus regalos al Niño Jesús, sentado en el regazo de su madre, que tiene a su lado a san José.

\section{4.- El ángel invita a José a huir a Egipto (Mt 2, 13)}

"El ángel del Señor se apareció en sueños a José y le dijo: Levántate, toma contigo al niño y a su madre y luego huye a Egipto y estate alli hasta que yo te lo diga" (Mt 2,13).

En medio de la noche José se incorpora en el lecho y escucha atento el anuncio del ángel que le ordena que escape de la furia de Herodes. 


\section{5.- La matanza de los inocentes (Mt 2,16)}

"Herodes (...) se enfureció terriblemente y envió a matar a todos los niños de Belén y de toda la comarca, de dos años para abajo" (Mt 2,16).

De casa en casa los soldados de Herodes están arrebatando los niños de los brazos de sus madres y les están matando. A unos los estrangulan; a otros les clavan una lanza; a otros más les golpean contra la pared y arrojan al suelo. (Ilustración 64)

\section{6.- Regreso de la Sda. Familia a Nazaret (Mt 2, 19-23)}

"Muerto Herodes, el ángel del Señor se apareció en sueño a José en Egipto y le dijo: ¡Levántate, toma contigo al niño y a su madre y vete a la tierra de Israel!" (Mt 2,19-20).

El diseño recoge el momento de la llegada a Nazaret de la Sagrada Familia. Son recibidos con gran alegría por parientes y vecinos. Mientras tanto, un criado está dando de beber a la cabalgadura que, cargada de equipaje, está sedienta, después del largo viaje.

\section{7.- Vida de la Sagrada Familia en Nazaret}

Se nos muestra una de las calles de Nazaret, un día de mercado, vista desde la carpintería de José. La calle está llena de gente, que va y viene entre los puestos de venta bajo los toldos. En primer plano, José, ayudado por Jesús niño, están serrando un tronco. Retirada, a un lado, se ve a María cosiendo.

\section{8.- Subiendo a Jerusalén (Lc 2, 41-42)}

Los padres de Jesús "iban todos los años a Jerusalén a la fiesta de la Pascua. Cuando cumplió los doce años subieron como de costumbre a la fiesta" (Lc 2, 41-42).

Se ve a Jesús correteando con otros niños de su edad que va junto a sus padres y otras muchas personas caminando hacia Jerusalén. La ciudad aparece al fondo, sobre una colina.

\section{9.- Regreso de Jerusalén sin Jesús (Lc 2, 43-45)}

"Al volver ellos, pasados los días, el Niño Jesús se quedó en Jerusalén, sin saberlo sus padres. Creyendo que estaría en la caravana hicieron un día de camino y le buscaban entre los parientes y conocidos (Lc 2,43-45).

Se nos muestra a María y a José de regreso de Jerusalén. Están echando de menos al niño Jesús. Al no encontrarlo entre la comitiva, se proponen volver a Jerusalén a buscarlo. 


\section{0.- María y José vuelven a Jerusalén buscando a Jesús (Lc 2, 45)}

“Al no encontrarlo se volvieron a Jerusalén en su busca” ( $\operatorname{Lc} 2,45)$.

Vemos a José corriendo y a María sobre la cabalgadura a galope, que regresan a Jerusalén. José parece que va preguntando a la gente si saben algo de Jesús. María lo está llamando en alta voz.

\section{1.- Jesús discutiendo con los doctores (Le 2, 46)}

"Al cabo de tres días lo encontraron en el templo sentado en medio de los maestros, escuchándolos y haciéndoles preguntas" $(\mathrm{Lc} 2,46)$.

El pequeño Niño Jesús, de pie, vestido con una túnica blanca, está dando explicaciones a siete doctores de la ley que, como dice el evangelio, “estaban estupefactos por su inteligencia y respuestas" (Lc 2, 47).

\section{2.- María y José encuentran a Jesús en el templo (Lc 2, 49-50)}

Se nos muestra el momento en el que María y José encuentran a Jesús entre los doctores, y a la pregunta de María. "Hijo, ¿por qué nos has hecho esto?, Jesús les contesta: “¿Por qué me buscabais? No sabíais que yo debía estar en la casa de mi Padre? Pero ellos no comprendieron la respuesta que les dio" ( Lc 2, 49-50). Al mismo tiempo señala con su mano al cielo, para indicar a qué Padre se está refiriendo.

\section{3.- La muerte de José}

Vemos a Jesús arrodillado a la cabecera de la cama de José, que está a punto de fallecer. Le tiene cogida la mano, como gesto de ternura y com-

pañía. Junto al lecho, de pie, está María, enjugándose las lágrimas por el dolor de la separación.

\section{4.- Jesús trabajando en la carpintería}

Jesús tenía que mantenerse a él y a su madre, viuda. Para ello se ganaba la vida trabajando en la carpintería. Aquí le observamos en plena faena sacando virutas a un tablón, con el rostro pensativo. En la pared están apoyadas unas tablas y colgada una sierra.

\section{5.- Jesús se despide de su madre}

Jesús toma de la mano a su madre, que está sentada, dentro de casa, a la orilla de una ventana. Con la otra mano indica al cielo y explica a su 
madre que, siguiendo su vocación, debe irse de casa para anunciar el Reino de Dios. Su madre le escucha comprensiva y, a la vez, adolorada. En la mano derecha tiene un pañuelo para enjugarse las lágrimas.

\section{6.- María contempla a Jesús que se aleja}

Tras la despedida, María observa, desde la ventana de casa, cómo Jesús se aleja por el camino, dirigiéndose hacia el desierto. Tiene la mente llena de inquietudes y preocupaciones, pensando en el futuro de su hijo.

\section{7.- Jesús orando en el desierto $(M t 4,1)$}

“Jesús fue llevado por el Espíritu al desierto para ser tentado por el diablo” (Mt 4,1).

En medio de un desierto árido y rocoso, Jesús está arrodillado orando, durante la noche, bajo un cielo estrellado. Tiene las manos juntas y el rostro dirigido hacia el cielo. Detrás de él, se acerca una serpiente y, por la derecha, viene rugiendo un león. (Ilustración 65)

\section{8.- Las tentaciones de Jesús (Mt 4, 7-10)}

Este diseño nos muestra la tercera de las tentaciones de Jesús en el desierto. Un diablo -diseñado al estilo típicamente chino-, le está mostrando las ciudades del mundo y le dice: "Todo esto te lo daré si, postrándote me adoras". A lo que Jesús, impasible, y con las manos juntas en oración, responde: “Apártate, Satanás, porque está escrito: Al Señor tu Dios adorarás y solo a él darás culto" (Mt 4, 9-10).

\section{9.- Los ángeles sirven a Jesús $(M t 4,11)$}

Tras las tentaciones "se acercaron unos ángeles y le servían" $(M t 4,11)$. El demonio, una vez vencido, se está retirando por la derecha. Mientras, por la izquierda, están descendiendo del cielo tres ángeles vestidos de blanco. El primero trae una bandeja con frutas y verduras; el segundo otra con una jarra de vino y una copa; y el tercero otra bandeja con panecillos y dulces.

\section{0.- Jesús va al encuentro de Juan el Bautista (Mt 3, 13)}

Jesús “viene de Galilea al Jordán, a donde Juan, para ser bautizado por él” (Mt $3,13)$.

Juan Bautista, vestido de piel, está a orillas del Jordán con un grupo de discípulos. A lo lejos, por una senda tortuosa, se ve acercarse a Jesús. Este 
tiene a sus espaldas unas hermosas montañas, diseñadas de la forma típica de la pintura china de paisaje. Todos, tanto Juan como sus discípulos, miran hacia él.

\section{1.- Bautismo de Jesús (Mt 3, 13-17)}

La obra representa la venida del Espíritu Santo sobre Jesús, después de ser bautizado por Juan. Este, metido dentro del río, mira sorprendido cómo la paloma desciende sobre Jesús. Parece que tanto él, como los discípulos que están de frente oyen la voz celeste que proclama: "Este es mi Hijo amado en quien me complazco” (Mt 3,17). (Ilustración 66)

\section{2.- Los primeros discípulos (Jn 1, 35-40)}

"Fijándose en Jesús que pasaba, Juan dice: He ahí el Cordero de Dios" (...) Andrés, el hermano de Simón Pedro, era uno de los dos que habían oído a Juan y habían seguido a Jesús" (Jn 1,35-40).

Este dibujo evoca, precisamente, este momento en el que los dos discípulos, Andrés y Juan, siguen a Jesús.

\section{3.- La vocación de Pedro (Jn 1, 41-42)}

Andrés, al encontrar a su hermano Simón, le dice: "Hemos encontrado al Mesías, que quiere decir el Cristo y le llevó a Jesús. Fijando Jesús su mirada en él, le dijo: Tú eres Simón, el Hijo de Juan. Tú te llamarás Cefas, que quiere decir "Piedra" (Jn 1, 41-42).

En este diseño vemos cómo Andrés está presentando a su hermano Simón a Jesús y este le interpela tal y como nos narra el evangelista Juan.

\section{4.- La vocación de Felipe (Jn 1, 43-44)}

"Al día siguiente Jesús encuentra a Felipe y le dice: ;Sígueme! Felipe era de Betsaida, de la ciudad de Andrés y Pedro" (Jn 1, 43-44).

En el diseño encontramos dentro de casa a Juan, Andrés, Pedro y a Jesús. Este último, desde el dintel de la puerta, está llamando a Felipe que pasa por la calle.

\section{5.- La vocación de Natanael (Jn 1, 45-51)}

"Vio Jesús que se acercaba Natanael y dijo de él: Ahí tenéis a un israelita de verdad, en quien no hay engaño" (Jn 1,47).

Felipe está conduciendo Natanael a la presencia de Jesús que lo acoge con palabras de aprecio. 


\section{6.- Jesús en las bodas de Cana (Jn 2, 1-12)}

Jesús, acompañado de su madre y los discípulos, entran en la sala del banquete de bodas. Allí se encuentran con los nuevos esposos. El esposo le está presentando a Jesús a la esposa.

\section{7.- La conversión del agua en vino ( Jn 2, 6-10)}

Jesús, a instancias de su madre, está invitando a los sirvientes que llenen de agua las tinajas vacías. Ellos obedecen y están realizando lo que Jesús les ordena.

\section{8.- EI Maestresala prueba el nuevo vino (Jn 2, 9-10)}

El maestresala -un personaje barbudo con turbante, ricamente vestido-, felicita a los novios por el nuevo vino, muy superior al anterior.

\section{9.- Jesús sube a la barca de Pedro (Lc 5, 3)}

"Subiendo a una de las barcas, que era la de Simón, le rogó que se alejase un poco de tierra" $(\operatorname{Lc} 5,3)$.

Vemos el momento en el que Jesús va a subirse a la barca de Pedro. Este se está acercando a la orilla para que Jesús pueda subir a bordo.

\section{0.- La pesca milagrosa $(\operatorname{Lc~} 5,4-7)$}

A instancia de Jesús, Pedro echa las redes y consigue capturar una gran cantidad de peces. Ante la imposibilidad de dominar la situación, pide ayuda a los compañeros de la otra embarcación, para que le echen una mano.

\section{1.- Pedro llamado a ser pescador de hombres (Lc 5, 8-11)}

Tras la pesca milagrosa, Pedro se postra ante Jesús sintiéndose pecador indigno. Este le dice: “iNo temas! Desde ahora serás pescador de hombres ( ...) y dejándolo todo le siguieron" (Lc 5, 10-11).

\section{2.- Entrevista con Nicodemo (Jn 3 1-21)}

En medio de la noche, el magistrado judío Nicodemo viene a visitar a Jesús, considerándolo un enviado de Dios. Aquí les vemos dialogando sentados a la luz de un candelabro. Jesús le dice: "El que no nazca de nuevo no puede ver el Reino de Dios” (Jn 3, 3). (Ilustración 67) 


\section{3.- Cómo nacer de nuevo (Jn 3, 3-21)}

Jesús explica a Nicodemo cómo nacer de nuevo, aunque se sea viejo. "En verdad en verdad te digo: el que no nazca del agua y del Espíritu no puede entrar en el Reino de Dios. Lo nacido de la carne es carne. Lo nacido del Espíritu es espíritu” (Jn 3,5).

\section{4.- Jesús y sus discípulos bautizando (Jn 3, 22)}

"Se fue Jesús con sus discípulos al país de Judea; y allí estaba con ellos bautizando" (Jn 3, 22).

El dibujo nos muestra a Jesús y sus discípulos, al lado de una cascada, que están bautizando a la gente que acude a ellos.

\section{5.- Jesús enseñando en la sinagoga de Nazaret (Lc 4, 16-30)}

En medio de una sinagoga abarrotada de gente, Jesús se está dirigiendo a los vecinos de Nazaret. Tras leer el texto de Isaías 61, 1-2 "El Espíritu del Señor está sobre mí, él afirma: "Esta escritura que acabáis de oír se ha cumplido hoy" (Lc 4,21). Los oyentes se escandalizan y lo expulsan de la ciudad.

\section{6.- Curación de un endemoniado en Cafarnaún (Lc 4, 31-37)}

Mientras Jesús estaba hablando en la sinagoga de Cafarnaún, un endemoniado se puso a gritar: “¿Qué tenemos nosotros contigo, Jesús de Nazaret? ¿Has venido a destruirnos? Sé quién eres: El Santo de Dios” (Lc 4,34).

Este es el momento que recoge el diseño, ante el asombro de todos los presentes.

\section{7.- Jesús expulsa al demonio $(\operatorname{Lc} 4,35)$}

"Jesús entonces le conminó diciendo:¡Cállate y sal de él! Y el demonio, arrojándole en medio, salió de él, sin hacerle ningún daño” (Lc 4,35).

$\mathrm{El}$ artista muestra la silueta negra de un demonio saliendo del cuerpo del hombre que estaba poseído. Este se postra de rodillas ante Jesús y lo adora.

\section{8.- Los amigos transportan un paralítico $(\operatorname{Lc} 5,18)$}

Una gran multitud intenta escuchar a Jesús que está predicando dentro de una casa. En primer plano "Unos hombres trajeron en una camilla a un paralítico y trataban de introducirlo, para ponerlo delante de él” $(\mathrm{Lc} 5,18)$.

La tarea parece imposible dada la afluencia de gente. 


\section{9.- Bajan al paralítico por el tejado $(\operatorname{Lc} 5,19)$}

"Pero, no encontrando por dónde meterlo, a causa de la multitud, subieron al terrado, le bajaron con la camilla a través de las tejas" (Lc 5, 19).

Los amigos han hecho un boquete en la azotea y por allí van a bajar al paralítico, para ponerlo delante de Jesús.

\section{0.- Tus pecados te son personados (Lc 5, 20)}

El paralítico es colocado delante de Jesús, en medio de una gran multitud. Jesús le dice. "Hombre, tus pecados te quedan perdonados" (Lc 5, 20). Los escribas y fariseos presentes, al oírlo empiezan a pensar. “¿Quién es este que dice blasfemias? ¿Quién puede perdonar pecados sino solo Dios? (Lc 5, 21).

\section{1.- Levántate, toma tu camilla y vete a tu casa (Lc 5, 23-25)}

Ante el asombro de todos los presentes, Jesús se dirigió al paralítico diciéndole "A ti te digo: Levántate, toma tu camilla y vete a tu casa”. Y, al instante (...) tomó la camilla en que yacía y se fue a su casa glorificando a Dios" (Lc 5, 24-25).

\section{2.- Se presenta ante Jesús un leproso (Lc. 5, 12-13)}

En medio de la gente se adelanta hacia Jesús un hombre con turbante, que tiene todo el rostro deformado. Es un leproso. Este ruega a Jesús: "Señor, si quieres puedes limpiarme. Él extendió la mano, le tocó y dijo: Quiero. Queda limpio” (Lc 5, 12-13).

Vemos el momento en el que Jesús le está tocando el rostro con la mano.

\section{3.- Curación del leproso (Lc 5, 13-14)}

Tras las palabras de Jesús "al instante desapareció la lepra” y le ordenó que no se lo dijese a nadie (Lc 5, 13-14).

$\mathrm{El}$ antiguo leproso, ahora sanado, se muestra la mar de feliz, y se está tocando la cara, constatando que es otro. La gente, sorprendida, comenta el acontecimiento.

\section{4.- La misión de los apóstoles de dos en dos (Mc 6,7)}

“Jesús llamó a los doce y comenzó a enviarles de dos en dos, dándoles poder sobre los espíritus inmundos” (Mc 6,7). 
Aquí se nos muestra a Jesús mandando en misión a dos de sus discípulos. Uno de ellos -vestido de verde y amarillo, con la bolsa en la mano-, es Judas.

\section{5-67.- El sermón de la montaña (Mt 5-6)}

Vemos a Jesús predicando. Detrás de él están Pedro y Juan; delante otros discípulos y un gran gentío. Les está instruyendo con las bienaventuranzas y otras cuestiones como la oración, el ayuno, el amor a los enemigos, la providencia... Estas enseñazas están resumidas en las pp. 66-67.

\section{8.- Regreso de la misión de los 72 (Lc 10, 17)}

"Regresaron los 72 y dijeron alegres: "Señor, hasta los demonios se nos sometían en tu nombre" (Lc 10,17).

Jesús se encuentra a la sombra de un árbol. Se nos muestra a los discípulos que, tras ir de misión de dos en dos, van regresando y le cuentan cómo los espíritus les obedecían. En medio de un amplio paisaje, se ve que van regresando por diversos caminos.

\section{9.- Retirado en Betsaida (Lc 9, 10)}

El evangelista Lucas cuenta que "cuando los apóstoles regresaron le contaron cuanto habían hecho y él, tomándolos consigo, se retiró aparte, hacia una ciudad llamada Betsaida” (Lc 9,10).

Aquí uno de los discípulos está dando cuenta a Jesús del éxito de la misión.

\section{0.- El emisario del centurión (Lc 7-1-10)}

Al entrar en Cafarnaún, el centurión le envió a un emisario para pedirle que fuese a salvar a uno de sus siervos. Aquí en el diseño, el siervo enviado, está llegando apresuradamente, para hacer la solicitud a Jesús.

\section{1.- No soy digno,... (Lc 7,8)}

Mientras iban de camino, el centurión mandó un emisario para decirle a Jesús: "No soy digno de que entres bajo mi techo (...) Mándalo de palabra y quedará sano mi criado” ( Lc 7,8), Jesús admira su gran fe.

El diseño muestra a un emisario a caballo que viene para decirle a Jesús que basta una orden suya. 


\section{2.- Jesús y los niños (Lc 18, 15-17)}

Sentado bajo un árbol contemplamos a Jesús rodeado de niños. Pacientemente está conversando con ellos, mientras, a un lado, sus madres están charlando.

\section{3.- Dejad que los niños vengan a mí (Lc 18, 15-17)}

Mientras está con los niños parece que uno de los discípulos intenta impedirlo, porque considera que están cansando al maestro. Jesús, indicando con su mano hacia el cielo, responde: "Dejad que los niños vengan a mí (...) porque de los que son como estos es el Reino de Dios” (Lc 18, 17).

\section{4.- Visita de Jairo (Lc 8, 40-50)}

"Llegó entonces un hombre llamado Jairo, que era jefe de la sinagoga, y cayendo a los pies de Jesús le suplicaba entrara en su casa, porque su hija única, de unos doce años, se estaba muriendo" (Lc 8. 41-42).

Este es el momento aquí representado. Jairo se inclina respetuosamente ante Jesús y le pide el favor.

\section{5.- Jesús llega a casa de Jairo (Lc 8, 48-56)}

Al llegar a casa de Jairo, Jesús encuentra en la habitación a la niña muerta, y a la madre y la criada en lágrimas. Él les dice: "No lloréis. No ha muerto, está dormida” (Lc 8, 52). El evangelista comenta que la gente se burlaba de Jesús, porque sabían que la niña estaba realmente muerta.

\section{6.- Resurrección de la hija de Jairo (Lc 8, 54-56)}

"Él, tomándola de la mano, dijo en voz alta: ¡Niña, levántate! Retornó el espíritu a ella y, al punto se levantó y él mandó que la dieran de comer" (Lc 8, 54$55)$.

El diseño recoge este momento, con la niña incorporándose en la cama y la alegría de los padres y la criada, que presenciaron el milagro. (Ilustración 68)

\section{7.- Entierro del hijo de la viuda de Naín (Lc 7, 11-17)}

Jesús se encuentra con el cortejo del entierro del hijo de la viuda de Naín. Cuatro porteadores están llevando el féretro. Al lado, su madre llora llena de tristeza. Jesús se acerca, lleno de compasión y le dice: “ No llores!” (Lc 7,13). 


\section{8.- Resurrección del hijo de la viuda de Naín (Le 7, 14-16)}

Jesús mandó detenerse el cortejo y, dirigiéndose al muerto, le dice: "¡Joven, a ti te lo digo, levántate! Y el muerto se incorporó y se puso a hablar y él se lo dio a su madre" (Lc 7, 14-15). En los rostros de los testigos se refleja en unos gran sorpresa, y, en otros, alegría. Un detalle curioso es, que el perro de la familia, está saltando, loco de contento, encima del féretro.

\section{9.- Solicitando la ayuda de Jesús}

Dentro de una estancia, Pedro se está dirigiendo a Jesús, en presencia de otros discípulos y le está pidiendo su intervención para liberar a un endemoniado que se está acercando.

\section{0.- Presentan a Jesús un endemoniado encadenado (Lc 8, 26-38)}

Podría tratarse del "Endemoniado de Gerasa” del cual dice el evangelio que "en muchas ocasiones un espíritu inmundo se apoderaba de él y, aunque lo sujetaban con cadenas y grillos para custodiarlo, rompía las ligaduras y el demonio le empujaba al desierto" $(\mathrm{Lc} 8,29)$.

Aquí, en el diseño, vemos que Pedro está pidiendo a Jesús que lo libere del maligno. Mientras, uno de los discípulos trata de sujetarlo y, detrás, una mujer llora.

\section{1.- Expulsión del demonio}

El endemoniado se arrodilla ante Jesús, que esta rodeado de sus discípulos. Jesús ordena al demonio que salga. El artista ha representado a un demonio negro y peludo, con grandes cuernos y orejas, y las manos convertidas en garras, que está saliendo del hombre que estaba poseído.

\section{2.- Multitud de gente sigue a Jesús $(\mathrm{Mt} 14,15)$}

Vemos a Jesús rodeado de gente en una región montañosa y desértica. Uno de los discípulos está, precisamente, aconsejándole que les despida: "despide pues a la gente para que vayan a los pueblos y se compren comida" (Mt 14, 15).

\section{3.- ¿Dónde nos procuraremos panes para que coman estos? $(\mathrm{Jn} 6,7)$}

A la pregunta de Jesús, el apóstol Felipe le contestó: “Doscientos denarios de pan no bastan para que cada uno tome un poco” (Jn 6,7). Este parece ser el diálogo que están manteniendo Jesús y Felipe en presencia de la multitud. 


\section{4.- El niño con cinco panes y dos peces $(\mathrm{Jn} 6,9)$}

Andrés, el hermano de Simón Pedro, le dice a Jesús: “Aquí hay un muchacho que tiene cinco panes de cebada y dos peces...” (Jn 6,9).

En la cromolitografía vemos al niño entregando a Jesús una bandeja con los cinco panes y los dos peces. Jesús lo está mirando con afecto y gratitud.

\section{5.- Jesús distribuyendo los panes $(\mathrm{Jn} 6,11)$}

“Tomó entonces Jesús los panes y, después de dar gracias, los repartió entre los que estaban recostados, y lo mismo los peces, todo lo que quisieron" (Jn 6,11).

Aquí vemos a Jesús distribuyendo los panes a los discípulos y a la gente, que se lo están llevando a la boca.

\section{6.- Canastos de panes sobrantes $(\mathrm{Jn} 6,13)$}

"Llenaron doce canastos con los trozos de los cinco panes de cebada que sobraron a los que habían comido" (Jn 6,13).

El dibujo nos muestra a Jesús ordenando que recojan lo que ha sobrado. Los discípulos lo están haciendo. En primer plano se ven ya nueve cestos llenos. (Ilustración 69)

\section{7.- Jesús huye al monte él solo $(\mathrm{Jn} 6,14-15)$}

"Sabiendo Jesús que intentaban venir a tomarle por la fuerza para hacerle rey, huyó de nuevo al monte él solo" (Jn 6,14-15).

Se nos muestra aquí a la multitud que está aclamando a Jesús, pero él se va alejando hacia la montaña.

\section{8.- Embarcándose para Cafarnaún (Jn 6, 16-17)}

"Al atardecer, bajaron sus discípulos a la orilla del mar y, subiendo a una barca, se dirigieron al otro lado del mar, a Cafarnaún" (Jn 6,16-17).

Vemos a los discípulos en el momento de embarcar y a Pedro y a Felipe charlando todavía en la orilla.

\section{9.- Jesús camina sobre las aguas (Mt 14, 24-25)}

"La barca se hallaba ya distante de la tierra muchos estadios, zarandeada por las olas, pues el viento era contrario. Y, a la cuarta vigilia de la noche, vino él hacia ellos caminando sobre el mar" (Mt 14,24-25).

En medio de la noche, la barca lucha contra el viento y las olas. En el horizonte aparece Jesús, con un manto rojo, caminando sobre las olas. (Ilustración 70) 


\section{0.- Creían que era un fantasma (Mt 14, 26-27)}

"Los discípulos, viéndole caminar sobre el mar, se turbaron y decían: Es un fantasma. Y de miedo se pusieron a gritar. Pero, al instante les habló Jesús y les dijo: ¡Ánimo! Soy Yo. ¡No temáis! (Mt 14, 26-27).

A un lado se ve a todos los discípulos en la oscuridad apiñados, unos junto a otros, llenos de temor. De frente, Jesús con la túnica blanca y el manto rojo, que les invita a no temer.

\section{1.- Pedro caminando sobre el mar (Mt 14, 28-31)}

"Bajó Pedro de la barca y se puso a caminar sobre las aguas yendo hacia Jesús. Pero viendo la violencia del viento, le entró miedo y, como comenzara a hundirse gritó: ¡Señor, sálvame! Al punto Jesús, tendiendo la mano le agarró y le dice: Hombre de poca fe ¿Por qué dudaste? (Mt 14, 28-31).

La escena representa gráficamente este episodio.

\section{2.- Se acercan a tierra $(M t 14,34)$}

“Terminada la travesía llegaron a tierra en Genesaret” (Mt 14,34).

El mar se ha calmado. Está amaneciendo. Jesús indica a los discípulos en la barca que están llegando a tierra.

\section{3.- Tomó Jesús consigo a Pedro, Santiago y Juan (Mt 17, 1)}

"Tomó Jesús consigo a Pedro, Santiago y a su hermano Juan y los llevó aparte a un monte alto" (Mt 17,1).

Aquí Jesús se está despidiendo de algunos apóstoles y se va hacia el monte con Pedro, Santiago y Juan. Es la escena que precede a la transfiguración.

\section{4.- La transfiguración (Mt 17, 2)}

" $Y$ se transfiguró ante ellos: su rostro se puso brillante como el sol y sus vestidos se volvieron blancos como la luz" (Mt 17,1-2).

Los tres discípulos contemplan a Jesús transfigurado. Del cielo baja un mensaje escrito en chino: "este es mi Hijo amado, en quien me complazco" (Mt 17,5).

\section{5.- No se lo contéis a nadie $(M t 17,9)$}

“Jesús les ordenó: no contéis a nadie la visión hasta que el Hijo del Hombre haya resucitado de entre los muertos" (Mt 17,9). 
En la cromolitografía vemos a Jesús haciendo esta advertencia a Pedro, Santiago y Juan.

\section{6.- Curaciones en el país de Genesaret (Mt 14, 34-35)}

“...Llegaron a tierra de Genesaret. Los hombres de aquel lugar, apenas le reconocieron, pregonaron la noticia por toda aquella comarca, y le presentaron todos los enfermos (Mt 14, 34-35).

Van al encuentro de Jesús varios cojos y lisiados con piernas amputadas, un leproso con la cara deformada y otros enfermos.

\section{7.- Curación de enfermos (Mt 14, 36)}

"Le pedían que tocaran siquiera la orla de su manto y cuantos lo tocaron quedaban salvados" (Mt 14,36).

Jesús, en este dibujo, está tocando a cojos y lisiados, que quedan curados. Un leproso, a la izquierda, se está tocando la cara. Loco de contento parece no creerse que haya quedado limpio.

\section{8.- Pedro protege el descanso de Jesús}

Un grupo de madres con sus hijos intenta acercarse a Jesús, que está sentado, descansando. Pedro se interpone en medio y trata de evitar que le molesten. Jesús le pide a Pedro que les permita acercarse.

\section{9.- Jesús y los niños (Lc 18, 15-17)}

Ante la mirada llena de sorpresa de Pedro, Jesús está jugando con los niños. A uno le está haciendo gestos con las manos; otros dos se le han subido a sus espaldas; un tercero le está haciendo una travesura desatándole las sandalias; otra niña observa.

\section{0.- Dejad que los niños se acerquen a mí (Lc 18, 15-17)}

A un cierto momento parece que Pedro quiere que los niños dejen a Jesús en paz. Pero el maestro replica: "Dejad que los niños vengan a mí y no se lo impidáis, porque de los que son como estos es el Reino de Dios” (Mt 18,15-17).

\section{1.- La mujer adúltera (Jn 8, 3-5)}

"Los escribas y fariseos le llevan una mujer sorprendida en adulterio (...) Moisés nos manda en la ley apedrear a estas mujeres ¿Tú qué dices? (Jn 8, 3-5).

La mujer está arrodillada en el suelo en medio de Jesús y los fariseos, esperando el veredicto. 


\section{2.- Quien esté sin pecado que tire la primera piedra (Jn 8,7)}

"Jesús, inclinándose, se puso a escribir con el dedo en la tierra (...) y les dijo: Aquel de vosotros que esté sin pecado que le arroje la primera piedra" (Jn 8,7).

En primer plano la mujer agachada en el suelo; a la derecha, Jesús escribiendo en la tierra; detrás los escribas y fariseos perplejos ante el interrogante de Jesús. (Ilustración 71)

\section{3.- Vete y en adelante no peques más (Jn 8, 10-11)}

"Incorporándose Jesús le dijo (...) Mujer, nadie te ha condenado (...) Tampoco yo te condeno. Vete y, en adelante, no peques más” (Jn 8,10-11).

Una vez puestos de pie, Jesús está despidiendo a la mujer con las palabras que nos cuenta Juan.

\section{4.- Curación del ciego de nacimiento (Jn 9, 1-7)}

"Vio, al pasar a un hombre ciego de nacimiento (...) escupió en tierra, hizo barro con la saliva y le dijo: Vete, lávate en la piscina de Siloé” (Jn 9, 1-7).

Se representa a Jesús untando con barro los ojos del ciego, ante el asombro de los presentes.

\section{5.- El ciego lavándose en la piscina de Siloé $(\mathrm{Jn}$ 9,7)}

"El fue, se lavó y volvió ya viendo" (Jn 9,7).

La cromolitografía muestra al ciego lavándose los ojos en la piscina, mientras los presentes le observan sorprendidos.

\section{6.- Los fariseos incrédulos (Jn 9, 13-34)}

Un fariseo, incrédulo está interrogando al ciego, y este le está respondiendo. No cree que fuese ciego de nacimiento y le pregunta: "¿Y tú qué dices de él, ya que te ha abierto los ojos? Él respondió: Que es un profeta” (Jn 9,17).

\section{7.- Jesús reencuentra al ciego (Jn 9, 35-38)}

Los fariseos repudian al ciego porque defiende que Jesús, que le ha curado, es alguien que viene de Dios. Reencontrándose con Jesús se postra ante él, reconociéndole como el Hijo del Hombre.

\section{8.- Invitación a casa de Simón (Lc 7,36-50)}

"Un fariseo le rogó que comiera con él y entrando en la casa del fariseo se puso a la mesa” (Lc 7, 36-50). 
Aquí tenemos el momento de la llegada de Jesús y sus discípulos a casa de Simón, que le da la bienvenida a la puerta.

\section{9.- La pecadora unge los pies de Jesús (Lc 7, 37-38)}

Una mujer pecadora está derramando un vaso de perfume sobre los pies de Jesús. Por detrás de ella, Judas parece reprobar la acción. Jesús, por su parte, deja actuar a la mujer y rechaza la postura de Judas.

\section{0.- Simón, tengo algo que decirte (Lc 7, 40-43)}

Los presentes, mientras la mujer unge los pies de Jesús, murmuran en su interior. Entonces Jesús cuenta a Simón la historia de los dos deudores. Este es el momento que representa la escena. (Ilustración 72)

\section{1.- Tus pecados quedan perdonados $(\mathrm{Lc} 7,48)$}

"Tus pecados quedan perdonados. Los comensales empezaron a decirse entre sí: ¿Quién es este que hasta perdona los pecados? Pero Jesús dijo a la mujer:Tu fe te ha salvado. Vete en paz" (Lc 7, 48-50).

Todos los ojos están puestos en Jesús y la mujer que está arrodillada ante él y escucha el mensaje liberador: ¡Vete en paz!

\section{2.- El joven rico (Lc 18, 18-22)}

"Se le acercó uno y le dijo: Maestro, ¿qué he de hacer de bueno para conseguir la vida eterna? (...) Si quieres entrar en la vida, guarda los mandamientos" (Lc 18, 18-22).

Jesús está respondiendo a un joven rico elegantemente vestido y con collar. Aquí el artista ha colocado este encuentro dentro del contexto del banquete.

\section{3.- ¿Qué más me falta? (Mt 19, 20-22)}

“¿Qué más me falta? Jesús le dijo: Si quieres ser perfecto, anda, vende lo que tienes y dáselo a lo pobres y tendrás un tesoro en los cielos; luego sígueme. Al oír estas palabras el joven se marchó entristecido, porque tenía muchos bienes"(Mt 19,20-22).

El grabado refleja el momento en el que el joven se aleja.

\section{4.- Te seguiré adondequiera que vayas ( $\operatorname{Lc} 9,57-58)$}

"Mientras iban de camino, uno le dijo: Te seguiré adondequiera que vayas. Jesús le dijo: Las zorras tienen guaridas y las aves del cielo nidos; pero el Hijo del Hombre no tiene donde reclinar la cabeza" (Lc 9, 57-58). 
Aquí en el diseño, Jesús está dirigiendo estas palabras al candidato. Entre ellos, en lugar de representar una zorra, pone a un perro en su caseta ${ }^{85}$.

\section{5.- Misión de los setenta y dos discípulos (Lc 10, 1-2)}

"Después de esto designó el Señor a otros setenta y dos y los envió por delante, de dos en dos, a todas las ciudades y sitios adonde él había de ir" (Lc 10,1).

En el grabado se ve a los discípulos, en grupos de dos en dos, mezclándose con la multitud.

\section{6.- Curación de dos ciegos (Mt 20, 29-34)}

“¿Qué queréis que os haga?. Dícenle: Señor que se abran nuestros ojos; y, al instante, recobraron la vista" (Mt 20,33-34).

En la imagen Jesús se está dirigiendo a los ciegos que le han llamado, preguntándoles qué es lo que desean.

\section{7.- La alegría de la curación}

Los dos ciegos del diseño anterior han recobrado la vista y se sorprenden mirándose el uno al otro. Se ven la cara por primera vez. La alegría es desbordante y ellos deciden seguir a Jesús.

\section{8.- La verdadera oración: el padrenuestro (Mt 6, 7-14)}

Aquí se nos presenta a Jesús instruyendo a sus discípulos en la oración. El diseño nos muestra el rostro de Jesús de perfil, orando, con Pedro detrás. La mitad del diseño lo ocupa el texto de las instrucciones.

\section{9.- Importantes instrucciones (Mt 6, 1-34)}

La imagen nos muestra a Jesús con la mano alzada instruyendo sobre algunos temas que están colocados en recuadros escritos encima de él: la oración secreta, el ayuno secreto, las obras de misericordia, la providencia.

\section{0.- Curación de los diez leprosos (Lc 17, 11-14)}

"Salieron a su encuentro diez leprosos (...) y levantando la voz dijeron: Jesús, maestro, ten compasión de nosotros. (...) El les dijo: Id y presentaos a los sacerdotes" (Lc 17,12-14).

\footnotetext{
${ }^{85}$ Agradecemos al Profesor Jesús Pérez, de la Universidad de Valladolid, la traducción de los textos chinos de los grabados 114 al 121, que nos han ayudado a la identificación de las imágenes.
} 
La imagen nos muestra a Jesús de espaldas, rodeado de los diez leprosos que suplican ser curados.

\section{1.- EI leproso agradecido (Lc 17, 15-19)}

"Uno de ellos, viéndose curado se volvió glorificando a Dios (...) y postrándose rostro en tierra a los pies de Jesús, le daba gracias; y este era un samaritano" (Lc 17,15-16).

El diseño representa, precisamente, al leproso arrodillado ante Jesús, dándole las gracias por la curación.

\section{2.- Avisan a Jesús de la enfermedad de Lázaro (Jn 11, 1-6)}

"Señor, aquel a quien tú quieres está enfermo" (Jn 11,3).

Mientras Jesús y sus discípulos estaban atendiendo a un enfermo, llega un emisario -enviado por Marta y María- que informa a Jesús de la enfermedad de Lázaro.

\section{3.- Jesús decide ir a ver a Lázaro (Jn 11, 7-11)}

"Volvamos de nuevo a Judea ( ...) Nuestro amigo Lázaro duerme, pero voy a despertarle" (Jn 11, 7 y 11).

Aquí vemos cómo Pedro y los demás discípulos tratan de disuadirle, pues hace poco que en Judea querían apedrearle. Pero, a pesar de todo, Jesús decide ir.

\section{4.- Jesús llega a casa de Lázaro (Jn 11)}

Jesús y sus discípulos llegan a casa de Lázaro. Allí le informan que lleva ya cuatro días enterrado. Sus hermanas Marta y María están en duelo. Aquí se las muestra llorando con un pañuelo en la mano, mientras dialogan con Jesús.

\section{5.- Diálogo entre Marta y Jesús (Jn 11, 21-28)}

Marta reprocha a Jesús que "si hubieras estado aquí no habría muerto mi hermano" (Jn 11,21). Jesús le responde: "Yo soy la resurrección. El que cree en mí, aunque haya muerto vivirá” (Jn 11,25-27). Y le invita a creer.

\section{6.- Jesús va al sepulcro de Lázaro (Jn 11, 32-38)}

Acompañado de Marta y María, Jesús va hacia el sepulcro donde han enterrado a Lázaro. En primer plano del grabado se ve a algunos que están criticando a Jesús: "Este que abrió los ojos al ciego ¿no podía haber hecho que este no muriera? (Jn 11,37). 
127.- Quitan la piedra del sepulcro de Lázaro (Jn 11, 39-41)

"¿No te he dicho que, si crees verás la gloria de Dios? Quitaron pues la piedra" (Jn 11, 39-41).

El grabado muestra el momento en el que están quitando la piedra. En primer plano se ve el cuerpo embalsamado de Lázaro. Al fondo, al quitar la losa, aparecen Jesús, con Marta y María.

\section{8.- ¡Lázaro, sal afuera! (Jn 11, 43)}

"Jesús se puso a orar al Padre y después gritó con fuerte voz: ;Lázaro sal afuera” (Jn 11, 43).

Vemos a Jesús a la boca del sepulcro dando la orden a Lázaro, mientras las hermanas están expectantes detrás. Inmediatamente, Lázaro obedece y comienza a incorporarse. Se ha retirado ya el paño que cubría su rostro.

\section{9.- ¡Desatadlo y dejadle andar! (Jn 11, 44)}

" $Y$ salió el muerto atado de pies y manos con vendas y envuelto el rostro en un sudario. Jesús les dice: ¡Desatadlo y dejadle andar!” (Jn 11, 44).

Vemos aquí cómo, ante la admiración de los presentes, Lázaro se ha puesto de pie. Sus hermanas, Marta y María, se han abalanzado sobre él y le están quitando las vendas.

\section{0.- Las autoridades judías deciden matar a Jesús (Jn 11, 45-54)}

Tras la resurrección de Lázaro, y ante el gran éxito de Jesús, los sacerdotes y fariseos "decidieron darle muerte" (Jn 11, 53).

El dibujo nos muestra a un grupo de fariseos, quienes, observando el éxito de Jesús, a quien sigue mucha gente, están organizando deshacerse de él.

\section{1.- Entrada triunfal en Jerusalén (Jn 12, 12-13)}

Vemos a Jesús -acompañado de sus discípulos-, caminar hacia la puerta de Jerusalén. Salen a su encuentro, corriendo, una gran multitud con palmas en sus manos ovacionándole:“ ¡Hosanna! ¡Bendito el que viene en nombre del Señor!” (Jn 12, 12-13).

\section{2.- Jesús entra montado en un borriquillo (Jn 12, 14-15)}

"Jesús, habiendo encontrado un borriquillo, se montó en él, según está escrito: No temas, Hija de Sión; mira que viene tu rey montado en un pollino de asna" (Jn 12, 14-15). 
Montado en un asno Jesús entra en Jerusalén. A su paso van poniendo en el suelo mantos. La muchedumbre le aclama. Muchos ondean palmas en sus manos.

\section{3.- Preocupación de los sacerdotes y fariseos $(\mathrm{Jn} 12,19)$}

El dibujo nos muestra en primer plano los rostros de dos sacerdotes y fariseos que están preocupados y hacen planes para eliminar a Jesús: “¿Veis cómo no adelantáis nada? Todo el mundo se ha ido con él” (Jn 12,19).

\section{4.- Jesús entra en el templo}

La cromolitografía nos muestra a Jesús entrando en el templo con sus discípulos. Delante de él se encuentra todo un mercado. Pueden verse mercaderes con palomas y cabras. En primer plano un cambista de dinero con su mesa llena de monedas, que está haciendo un trato con un cliente.

\section{5.- Expulsión de los mercaderes (Mt 11, 15-19)}

"Entrando en el templo comenzó a echar fuera a los que vendían (...) volcó las mesas de los cambistas y los puestos de los que vendían palomas" (Mt 11,15).

Jesús, con un látigo en la mano, está expulsando a los mercaderes del templo. (Ilustración 73)

\section{6.- Mi casa es casa de oración $(\mathrm{Mt} 11,17)$}

"Mi casa será llamada casa de oración, para todas las gentes. Pero vosotros la tenéis hecha una cueva de bandidos" (Mt 11,17).

En el diseño tenemos en primer plano a Jesús proclamando la sacralidad del templo. Frente a él, por un lado, los mercaderes que están huyendo aterrorizados y, por otro, los sacerdotes que vienen a rechazar el comportamiento de Jesús.

\section{7.- Enfrentamiento con los sacerdotes $(\mathrm{Mc} 11,18)$}

"Se enteraron de esto los sumos sacerdotes, y los escribas y buscaban cómo podrían matarle; porque le tenían miedo, pues toda la gente estaba asombrada de su doctrina" (Mc 11, 18).

Jesús se está enfrentando a un sacerdote y a un escriba que están delante de él.

\section{8.- El óbolo de la viuda (Le 21, 1-4)}

En primer plano vemos a la viuda, de espaldas, depositando su óbolo. Más allá está Jesús denunciando la falsedad de las apariencias: "todos estos 
(los ricos) han echado como donativo lo que les sobra. Esta, en cambio, ha echado de lo que necesita, de todo lo que tiene para vivir" (Lc 21, 1-4).

\section{9.- Conspiración de Judas (Lc 22, 3)}

"Satanás entró en Judas, llamado Iscariote, que era un de los doce" (Lc 22, 3).

Judas, comenzó a tramar cómo entregar a Jesús. En este grabado podemos observar en primer plano el rostro de Judas -que el artista representa con apariencia de malvado-, que está espiando los movimientos de Jesús.

\section{0.- Judas vende a Jesús por 30 monedas de plata (Mt 26, 14-16)}

"Judas fue a ver a los sumos sacerdotes y les dijo: ¿Qué queréis darme y yo os lo entregaré? Ellos le asignaron 30 monedas de plata y, desde ese momento andaba buscando una oportunidad para entregarle "(Mt 26,16-16).

El grabado nos muestra el momento en el que Judas está sellando el acuerdo con los sumos sacerdotes.

\section{1.- Preparativos para la Pascua (Lc 22, 7-13)}

"Llegó el día de los Ácimos (...) y envió a Pedro y a Juan diciendo: ;Id y preparadnos la Pascua para que la comamos! Ellos le dijeron: ¿Dónde quieres que la preparemos? ( $\mathrm{Lc} 22,7-9)$. Y les dio las instrucciones.

En este dibujo se nos muestra precisamente el momento en el que Jesús le está dando instrucciones a Pedro.

\section{2.- Pedro encuentra al hombre con el cántaro de agua $(\operatorname{Lc~22,10)}$}

"Cuando entres en la ciudad os saldrá al paso un hombre que lleva un cántaro de agua; seguidle hasta la casa en que entre" (Lc 22,10).

Vemos a Pedro entrando en la ciudad y encontrándose con el hombre que lleva el cántaro de agua, tal y como Jesús les había dicho.

\section{3.- ¿Dónde está la sala para celebrar la Pascua? (Lc 22, 11-12)}

"El Maestro te dice: ¿Dónde está la sala donde pueda comer la Pascua con mis discípulos? El os enseñará en el piso superior una sala grande bien dispuesta. Haced alli los preparativos" (Lc 22, 11-12).

El dueño de la casa -donde le condujo a Pedro el hombre del cántaro-, le está señalando una sala en la planta superior.

\section{4.- Preparando la Pascua (Lc 22, 13)}

"Fueron y lo encontraron tal y como les había dicho Jesús y prepararon la Pasсиа" (Lc 22,13). 
El diseño nos muestra a Pedro dando órdenes a uno de los sirvientes. En primer plano se ve una mesa con panes, frutas, vino y un cordero; detrás, una gran mesa elíptica y, al lado, los lugares para recostarse.

\section{5.- Jesús lava los pies de los discípulos (Jn 13, 3-5)}

"Durante la cena (...) se levantó de la mesa, se quitó sus vestidos y, tomando una toalla se la ciñó. Luego echó agua en un librillo y se puso a lavar los pies de los discípulos y a secárselos con la toalla con que estaba ceñido" (Jn 13, 3-5).

Mientras Jesús lava los pies a los discípulos, se nos muestra a Pedro, a un lado, de pie, receloso, mirando a Jesús. (Ilustración 74)

\section{6.- Señor, ¿tú lavarme a mí los pies? (Jn 13, 6-8)}

"Llega a Simón Pedro. Este le dice: Señor ¿̇ú lavarme a mí los pies? (...) No me lavarás los pies jamás. Jesús le respondió: "Si no te lavo no tienes parte conmigo" (Jn 13, 6-8).

El diseño escenifica este diálogo entre Jesús y Pedro, que, a toda costa, se resiste a que Jesús le lave los pies.

\section{7.- No solo los pies,... (Jn 13, 9-10)}

"Señor, no solo los pies, sino también hasta las manos y la cabeza" (Jn 13, 9-10).

Tras la resistencia inicial, Pedro cede. Aquí le vemos ya dispuesto a que Jesús le lave los pies.

\section{8.- Uno de vosotros me va a entregar (Jn 13, 21-30)}

El diseño nos muestra a Jesús recostado a la mesa, entre Juan y Judas. Tras declarar que "Uno de vosotros me va a entregar" (Jn 13,21) Juan le pregunta ¿Quién es? Y Jesús responde que aquel a quien le dé el bocado. Aquí en la pintura Jesús está entregando a Judas un cuenco, en lugar de un bocado.

\section{9.- Esto es mi cuerpo (Lc 22, 19)}

"Tomó luego pan, dio gracias, lo partió y se lo dio diciendo: este es mi cuerpo que se entrega por vosotros" ( $\mathrm{Lc} 22,19)$.

Jesús, de pie, en el grabado, está elevando el pan hacia lo alto, mientras los discípulos, recostados, adoran con reverencia.

\section{0.- Esto es mi sangre (Lc 22, 20)}

Aquí se nos muestra a Jesús arrodillado, con el cáliz en la mano, frente a sus discípulos, que están recostados mirando con reverencia. Entonces él 
dijo: "Esta copa es la Nueva Alianza en mi sangre que se derrama por vosotros” (Lc 22, 20).

\section{1.- Os doy un mandamiento nuevo (Jn 13, 34-35)}

"Os doy un mandamiento nuevo: que os améis los unos a los otros" ( Jn 13,34).

Jesús se está dirigiendo a los discípulos, que lo escuchan con reverencia, inclinados y con las manos juntas.

\section{2.- Yo he rogado por ti (Lc 22, 31-32)}

"Simón (... yo he rogado por ti para que tu fe no desfallezca. Y tú cuando hayas vuelto, confirma a tus hermanos" (Lc 22, 31-32).

Jesús se está dirigiendo a Pedro. Todos los presentes están escuchando con atención.

\section{3.- Me negarás tres veces (Lc 22, 33-34)}

En primer plano se presenta a Jesús, cara a cara, frente a Pedro, anunciando que va a renegar de él. Simón Pedro replica: "Señor, estoy dispuesto a ir contigo hasta la cárcel y la muerte. Pero él contestó: Te digo, Pedro, que antes de que cante el gallo, habrás negado tres veces que me conoces" (Lc 22, 33-34).

\section{4.- La hora del combate (Lc 22, 37-38)}

El diseño nos muestra a un Jesús grave, anunciando que llegan tiempos difíciles. Dice a sus discípulos: "Es necesario que se cumpla en mí esto que está escrito: ha sido contado entre los malhechores. Porque lo que se refiere a mí, toca a su fin. Ellos dijeron. Señor, aquí hay dos espadas. Él les dijo: ¡basta!” (Lc 22, 37-38).

\section{5.- Salió hacia el Monte de los Olivos $(\operatorname{Lc} 22,39)$}

"Salió y, como de costumbre, fue al Monte de los Olivos. Los discípulos le siguieron" (Lc 22, 39).

El artista nos representa a la comitiva, en medio de la noche estrellada, atravesando un puente sobre el torrente Cedrón.

\section{6.- Quedaos aquí y velad conmigo (Mt 26, 36-38)}

"Tomando consigo a Pedro y a los dos hijos de Zebedeo comenzó a sentir tristeza y angustia. Entonces les dice: Mi alma está triste hasta el punto de morir, quedaos aquí y velad conmigo" (Mt 26,36-38). 
Entre olivos, de pie, Jesús pide a tres de sus discípulos que velen con él.

\section{7.- Jesús ora mientras los discípulos duermen (Mt 26, 39-44)}

Jesús se aparta un poco de sus discípulos y, de rodillas -con el rostro elevado al cielo y las manos juntas-, ora al Padre. Mientras, a la izquierda, los tres discípulos, Pedro, Juan y Santiago, se han quedado dormidos.

\section{8.- Aparta de mí este cáliz (Mt 26, 39)}

"Padre mío, si es posible, que pase de mi esta copa, pero no sea como yo quiero, sino como quieres tú" (Mt 26,34).

Jesús ora al Padre con estas palabras. En el grabado contrasta el color blanco de la túnica de Jesús, frente al negro y el verde del tronco y las ramas de los olivos.

\section{9.- No habéis podido velar ni una hora (Mt 26, 40-41)}

Vemos a los tres discípulos desperezarse, mientras Jesús les reprocha que no hayan velado con él: “¿No habéis podido velar una hora conmigo?. Velad y orad, para que no caigáis en tentación; que el espíritu está pronto, pero la carne es débil” (Mt 26, 40-41).

\section{0.- EI beso de Judas (Lc 22, 47-48)}

“...se acercó a Jesús para darle un beso. Jesús le dijo: Judas, con un beso entregas al Hijo del Hombre" (Lc 22, 47-48).

En el centro del grabado Judas está besando a Jesús. Esta era la señal para que los soldados supiesen a quién tenían que prender. A un lado están los soldados con lanzas y antorchas; al otro, Pedro y los discípulos. (Ilustración 75)

\section{1.- Pedro corta una oreja a Malco (Jn 18, 10-11)}

"Entonces Simón Pedro, que llevaba una espada, la sacó e hirió al siervo del sumo sacerdote, y le cortó la oreja derecha. El siervo se llamaba Malco” (Jn 18, 10-11).

De forma muy gráfica, el artista ha representado este hecho. Jesús, con una mirada desaprueba el comportamiento de Pedro.

\section{2.- Tocándole la oreja, le curó (Lc 22, 51)}

Después de que Pedro cortase la oreja a Malco, Jesús interviene diciendo: "Basta ya. Y tocando la oreja le curó” (Lc 22, 51). 
En el grabado vemos a Jesús colocando la oreja en su sitio, mientras dirige una mirada de desaprobación a Pedro, que está envainando la espada.

\section{3.- Prendimiento de Jesús (Lc 22, 52-53)}

"Como contra un salteador habéis salido con espadas y palos. Estaba yo todos los días con vosotros y no me pusisteis las manos encima; pero esta es vuestra hora y el poder de las tinieblas" (Lc 22, 52-53).

Jesús está increpando a los que han venido a prenderlo. Delante tiene soldados con lanzas, al lado, ancianos con palos; por detrás se ve a Pedro y Juan.

\section{4.- Los discípulos a la fuga}

En este grabado se ve la gran soledad de Jesús. Frente a él, sus enemigos con antorchas, espadas y lanzas. Por detrás, los discípulos que se han dado a la fuga corriendo y dejándole solo.

\section{5.- Esposado entre dos soldados}

Vemos a Jesús por detrás, con las manos esposadas a la espalda. Es escoltado por cuatro soldados. Uno de ellos le lleva agarrado por la túnica.

\section{6.- Llevado a casa del sumo sacerdote}

La comitiva de los soldados con lanzas, espadas y antorchas, que llevan apresado a Jesús, están subiendo por las escaleras de la casa del Sumo Sacerdote.

\section{7.- Jesús ante Caifás (Mt 26, 57-59)}

"Los que prendieron a Jesús le llevaron ante el sumo sacerdote, Caifás, donde se habían reunido los escribas y ancianos,...” (Mt 26, 57).

Jesús, entre dos soldados, está siendo interrogado por Caifás, en presencia del sanedrín.

\section{8.- Si he hablado bien ¿Por qué me pegas? (Jn 18, 19-23)}

"Apenas dijo esto, uno de los guardias que allí estaba, dio una bofetada a Jesús diciendo: ¿Así contestas al sumo sacerdote? Jesús le respondió: Si he hablado mal, declara lo que está mal; pero si he hablado bien, ¿por qué me pegas?

Uno de los soldados está dando una bofetada a Jesús, mientras el resto de los presentes le acusan con el dedo. 


\section{9.- Es reo de muerte (Mt 26, 63-66)}

"Te conjuro, por Dios vivo, que nos digas si tú eres el Cristo, el Hijo de Dios. Dícele Jesús: Tú lo has dicho (...) Entonces el sumo sacerdote rasgó sus vestiduras y dijo: Ha blasfemado (...) iEs reo de muerte!” (Mt 26, 63-66).

Todos los presentes le están señalando con el dedo y condenando a muerte.

\section{0.- Negaciones de Pedro (Lc 22, 54-57)}

"Habian encendido una hoguera en medio del patio y estaban sentados alrededor. Pedro se sentó entre ellos. Una criada (...) se le quedó mirando y le dijo: Este también estaba con él. Pero Pedro lo negó: Mujer, no le conozco" (Lc 22, 54-57).

El grabado nos muestra el momento en el que estando alrededor del fuego, Pedro niega por tres veces que conoce a Jesús. En el ángulo se ve un gallo cantando.

\section{1.- El Señor se volvió y miró a Pedro (Lc 22, 60-62)}

"El Señor se volvió y miró a Pedro. Recordó Pedro las palabras que le había dicho el Señor:Antes que cante hoy el gallo, me habrás negado tres veces" (Lc 22, 60-62).

Se representa aquí el momento en el que, tras las negaciones, Pedro se cruza la mirada con Jesús.

\section{2.- Pedro rompió a llorar amargamente (Lc 22, 62)}

“...y saliendo fuera rompió a llorar amargamente $(\mathrm{Lc} 22,62)$.

En este grabado se nos muestra un doble arrepentimiento. Por un lado, Pedro, que, tras las negaciones, se echa a llorar; por otro, Judas, que regresa corriendo ante los sumos sacerdotes para devolverles el dinero que le han dado por entregar a Jesús.

\section{3.- Pequé entregando sangre inocente (Mt 27, 3-5)}

"Entonces Judas, el que le entregó, viendo que había sido condenado, fue acosado por el remordimiento y devolvió las treinta monedas de plata a los sumos sacerdotes y a los ancianos diciendo: Pequé entregando sangre inocente. Ellos dijeron: a nosotros ¿qué? Tú verás. Él tiró las monedas en el santuario” (Mt 27, 3-5).

Se nos muestra a Judas ante los sumos sacerdotes que está vaciando su bolsa y arrojando las monedas al suelo. 


\section{4.- Judas tirando al suelo las monedas (Mt 27, 6)}

"Los sumos sacerdotes recogieron las monedas" (Mt 27,6).

Esta es una escena dramática y jocosa a la vez. Dramática, porque Judas está realmente amargado y las 30 monedas le queman en las manos y las está arrojando al suelo; jocosa, porque muestra la avidez y avaricia de los sumos sacerdotes y ancianos que se están apresurando a tirarse al suelo para recogerlas.

\section{5.- Fue y se ahorcó (Mt 27, 5)}

$$
\text { “..después se retiró y fue y se ahorcó” (Mt 27,5). }
$$

Se trata de una escena trágica en medio de la noche. Judas, desesperado, se ha ahorcado en uno de los olivos. Parece querer aflojarse la cuerda que lleva al cuello. Pero ya es tarde. Está sacando la lengua fuera de la boca y ha perdido ya una de sus sandalias. (Ilustración 76)

\section{6.- Se pusieron a escupirle en la cara (Mt 26, 67)}

"Se pusieron a escupirle en la cara y a abofetearle" (Mt 26, 67).

Jesús, indefenso, con las manos atadas a la espalda, está rodeado de soldados que le están pegando y escupiendo.

\section{7.- Adivina, ¿quién es el que te ha pegado? (Lc 22, 63-65)}

"Los hombres que le tenían preso se burlaban de él y le golpeaban. Y cubriéndole con un velo le preguntaban: ¡Adivina! ¿Quién te ha pegado? (Lc 22, 63-65).

Con gran realismo se representa esta escena. Unos soldados están pegando a Jesús con palos, otros se ríen. Otro lo interroga. Jesús calla y llora. Por debajo de la venda se ven caer las lágrimas rostro abajo. (Ilustración 77)

\section{8.- ¿Qué acusaciones traéis contra este hombre? (Jn 18, 28-32)}

"Salió Pilato fuera hacia ellos y dijo: ¿Qué acusación traéis contra este hombre? Si este no fuera malhechor no te lo habríamos entregado" (Jn 18, 28-30).

Jesús está dentro del Pretorio, con las manos atadas a la espalda. Un soldado lo tiene agarrado por la túnica. Pilato está saliendo hacia el balcón para dialogar con los acusadores de Jesús.

\section{9.- ¿Eres tú el rey de los judíos? (Jn 18, 33-37)}

"Pilato llamó a Jesús y le dijo: ¿eres tú el Rey de los Judíos? (...) Sí, como tu dices, soy Rey” (Jn 18, 33-37). 
Solo en un salón -frente a Pilato sentado en su trono-, Jesús contesta al interrogatorio que le está haciendo el procurador de Roma.

\section{0.- ¿Qué es la verdad? (Jn 18, 37-38)}

En un plano de medio cuerpo Jesús está frente a Pilato al que le dice: "Yo para esto he nacido y para esto he venido al mundo, para dar testimonio de la verdad. Todo el que es de la verdad escucha mi voz”. Le dice Pilato: ¿Qué es la verdad? (Jn 18, 37-38).

\section{1.- No encuentro ningún delito en él $(\mathrm{Jn} \mathbf{1 8 , 3 8 )}$}

"Yo no encuentro ningún delito en él" (Jn 18,38).

Tras interrogar a Jesús, Pilato comunica al pueblo que no encuentra delito en él. Pero los presentes insisten en que lo condene. El diseño nos muestra a un Pilato impotente ante una turba encendida, que pide sangre.

\section{2.- Pilato manda azotar a Jesús (Jn 19, 1)}

"Pilato tornó a Jesús y mandó azotarlo" (Jn 19,1).

Ante la insistencia del pueblo de que castiguen a Jesús, aquí Pilato está dando la orden de castigo. Al fondo del grabado se ve a un soldado que está llevando a Jesús para azotarlo.

\section{3.- Los azotes de Jesús atado a la columna}

Jesús está atado a una columna con cadenas. Ha recibido ya muchos azotes y está medio agotado, en el suelo. Su cuerpo, semidesnudo está sangrando. A pesar de ello, dos soldados siguen azotándolo con saña, mientras otros dos, detrás, observan. (Ilustración 78)

\section{4.- El manto de púrpura (Mt 27, 27-28)}

"Entonces los soldados del procurador llevaron consigo a Jesús al pretorio y reunieron alrededor de él a toda la cohorte. Le desnudaron y le echaron encima un manto de púrpura" (Mt 27,27-28).

Jesús, abatido y sin fuerzas, está semidesnudo sentado en el suelo. Un soldado intenta reincorporarlo, mientras otro le pone encima un manto de púrpura. Otros seis observan divertidos la escena.

\section{5.- La coronación de espinas (Mt 27, 29)}

"Trenzando una corona de espinas se la pusieron sobre la cabeza y en su mano derecha una caña” (Mt 27,29). 
Un soldado está colocando la corona de espinas sobre la cabeza de Jesús; otro le está dando una caña; y los demás se mofan.

\section{6.- ¡Salve, Rey de los Judios! (Mt 27, 29-30)}

"Doblando la rodilla delante de él, le hacían burla diciendo: ;Salve, Rey de los Judios! Y después de escupirle, cogieron la caña y le golpearon en la cabeza" (Mt 27, 29-30).

Los soldados se están mofando de Jesús, vestido con un manto de púrpura y coronado de espinas.

\section{7.- Pilato se lava las manos (Mt 27, 24-25)}

"Pilato (...) tomó agua y se lavó las manos delante de la gente diciendo: Inocente soy de la sangre de este justo. Vosotros veréis” (Mt 27,24-25).

A un lado, vemos a Pilato lavándose las manos; al otro, a un soldado llevando a Jesús hacia el balcón; al centro, el pueblo que grita: ¡Crucifícalo!

\section{8.- "Ecce Homo" (Jn 19, 4-6)}

"Salió entonces Jesús fuera, llevando la corona de espinas y el manto de púrpura. Díceles Pilato: ¡Aquí tenéis al Hombre! Cuando lo vieron los sumos sacerdotes y los guardias gritaron: ¡Crucifícale! ¡Crucificale! (Jn 19, 4-6).

El diseño representa gráficamente esta escena.

\section{9.- ¡Crucifícale! (Mt 23, 20-22)}

"Pilato le habló de nuevo con la intención de liberar a Jesús, pero ellos seguían gritando: ¡Crucificale! ¡Crucifícale! (Mt 23, 20-22).

Pilato hace un esfuerzo por liberar a Jesús, pero la gente, instigada por los sacerdotes, grita y le exige que lo crucifique.

\section{0.- Jesús o Barrabás (Mt 27, 15-22)}

"Les dijo Pilato: ¿A quién queréis que os suelte a Barrabás o a Jesús? (...) Respondieron: A Barrabás. Díceles Pilato: Y que voy a hacer con Jesús, el llamado Cristo? Dicen todos: ¡Sea crucificado!” (Mt 27,15-22).

En el estrado está representado Pilato al centro y, a un lado, Barrabás y, al otro, Jesús. Frente a ellos, el pueblo gritando que crucifiquen a Jesús y liberen a Barrabás.

\section{1.- Camino del calvario (Mt 27,31)}

"Cuando se hubieron burlado de él, le quitaron el manto, le pusieron sus ropas y le llevaron a crucificarle" (Mt 27,3). 
En medio de un gran gentío se está preparando la marcha de Jesús y los otros dos ajusticiados, camino del calvario. Van a poner la cruz sobre los hombros de cada uno de ellos.

\section{2.- Jesús cae por primera vez}

Cansado y agotado como está, después de las torturas sufridas, Jesús cae por primera vez bajo el peso de la pesada cruz. Los esbirros le azotan; otro lo lleva atado con cuerdas y tira de ellas para que se incorpore y siga caminando.

\section{3.- Jesús encuentra a su madre}

Camino del calvario, Jesús encuentra a su madre. Ella intenta acercarse a él, cuando está caído en el suelo, pero uno de los soldados se lo impide. Mientras, otro, lo azota para que se levante. (Ilustración 79)

\section{4.- Intercambio de miradas entre Jesús y su madre}

Los soldados impiden que madre e hijo se encuentren. Ambos se miran uno a otro entre lágrimas. Mientras, Jesús intenta ponerse de pie, cargando con el pesado madero de la cruz.

\section{5.- La Verónica enjuga el rostro de Jesús}

Una joven, conocida como "La Verónica” consigue acercarse hasta Jesús. Con un paño seca el sudor, las lágrimas y la sangre de su rostro. Un soldado intenta separarla de Jesús ${ }^{86}$.

\section{6.- La Santa Faz}

La Verónica queda admirada al contemplar que el rostro de Jesús ha quedado impreso en su lienzo. También el soldado muestra una expresión de sorpresa. Mientras, Jesús sigue adelante, sereno, con la cruz a cuestas.

\section{(Ilustración 80)}

\section{7.- Jesús cae por segunda vez}

Aunque a Jesús le llevan atado con unas cuerdas al pecho y a los hombros, para que se mantenga en pie, su debilidad es grande, y el peso de la cruz también. Todo ello hace que de nuevo caiga en tierra por segunda vez.

${ }^{86}$ REAU, Louis, Iconografía de los santos Vol. 2, P-Z, Ediciones del Serbal, Barcelona 2001, pp. 315-319. Aquí se explica la leyenda sobre la Verónica y las diversas iconografías de la misma. 
198.- Jesús y las mujeres de Jerusalén (Lc 23, 27-32)

"Le seguían una gran multitud del pueblo y mujeres que se dolían y se lamentaban por él. Jesús se volvió a ellas y les dijo: Hijas de Jerusalén. No lloréis por mí. Llorad más bien por vosotras y por vuestros hijos" (Lc 23, 27-28).

Vemos a Jesús dirigiéndose hacia un grupo de mujeres que están llorando y llevan pañuelos en las manos.

\section{9.- Jesús cae por tercera vez}

Se nos muestra a Jesús arrodillado en tierra. Delante, se ve el pie y la pantorrilla de un soldado, protegida con una placa metálica. En primer plano un perro le está ladrando para que se levante.

\section{0.- ¿Soldado amigo o enemigo?}

Jesús está en tierra abatido por el peso de la cruz. Vemos que un soldado se agacha y le agarra del brazo, pero, al mismo tiempo, con el pie le está pisando la mano. Jesús le fija la mirada interrogante.

\section{1.- El Cireneo ayuda a Jesús a llevar la cruz $(\mathrm{Lc} 23,26)$}

"Echaron mano de un cierto Simón de Cirene, que venía del campo, y le cargaron con la cruz, para que la llevara detrás de Jesús" (Lc 23, 26).

Están subiendo unas escaleras. El camino se hace más difícil. El Cireneo carga la cruz sobre sus espaldas. Jesús va a su lado, ya sin fuerzas, seguido por los soldados. (Ilustración 81)

\section{2.- El expolio}

Llegados al calvario los soldados desnudan a Jesús. Este se encuentra débil. Ya no se tiene en pie. Está sentado en el suelo. Al quitarle la túnica, aparece el cuerpo desnudo, ensangrentado, todo lleno de heridas. Por detrás, un soldado intenta alejar a las santas mujeres.

\section{3.- Jesús colocado sobre la cruz}

Jesús, está tan agotado, que no tiene fuerzas para moverse por sí mismo. Dos de los esbirros levantan su cuerpo -como un cuerpo muerto-, y lo están colocando sobre la cruz tendida en el suelo.

\section{4.- Los golpes del martillo}

Es un primer plano de una fuerza increíble. El martillo del verdugo parece estar bajando con fuerza sobre el clavo que está siendo introducido 
en la muñeca de Jesús. Puede también verse su brazo lleno de heridas, atado con cuerdas al madero, su rostro sangrante y la cabeza coronada de espinas. (Ilustración 82)

\section{5.- Los clavos y las cuerdas}

Jesús se encuentra semidesnudo, extendido sobre la cruz. Uno de los verdugos le está atando el brazo derecho al madero, mientras que el otro le está clavando el brazo izquierdo. Jesús, desde el suelo, tiene la mirada dirigida hacia el cielo.

\section{6.- Lágrimas de la Magdalena}

Los pies de Jesús están atados a la cruz. Un verdugo comienza a sujetarlos al madero, con un clavo. En ese momento una mujer -la Magdalena en lágrimas-, le agarra por el brazo para impedírselo. Por la esquina aparece otro brazo más fuerte, de un soldado, que quiere alejar a la joven de la escena.

\section{7.- Alzando a Jesús crucificado}

Una vez que el cuerpo de Jesús fue clavado al madero, los verdugos levantan la cruz con el crucificado. Unos están tirando de las sogas atadas a los travesaños; otros están empujando por detrás. Al lado izquierdo, se ven a las santas mujeres llorando.

\section{8.- Jesús es ultrajado en la cruz (Lc 23, 35-38)}

La cruz de Jesús se levanta en medio de otras dos cruces de dos malhechores, ajusticiados también con él. Frente a ellos, a sus pies, está una multitud que increpa a Jesús: "Ha salvado a otros; que se salve a sí mismo si el es el Cristo de Dios, el Elegido” (Lc 23, 35).

\section{9.- El mal ladrón (Lc 23, 39)}

Uno de los malhechores que estaba crucificado al lado de Jesús se dirige a él de modo insultante: “ ¿ No eres tú el Cristo? Pues sálvate a ti y a nosotros? (Lc 23, 39). Jesús no le responde. De las heridas causadas por los clavos se ve gotear la sangre.

\section{0.- El buen ladrón (Lc 23, 41-43)}

El buen ladrón, crucificado también al lado de Jesús, reconoce que él "nada malo ha hecho" a diferencia de ellos y, desde la cruz, invoca a Jesús 
diciéndole: “Jesús, acuérdate de mí cuando vengas con tu Reino. Jesús le dijo: Te aseguro que hoy estarás conmigo en el Paraíso” (Lc 23, 42-43).

\section{1.- ¡Mujer, ahí tienes a tu hijo! (Jn 19, 25-27)}

"Jesús, viendo a su madre y, junto a ella, al discípulo a quien amaba, dice a su madre: Mujer, ahí tienes a tu hijo. Luego dice al discípulo: Ahí tienes a tu madre. $Y$ desde aquella hora el discípulo la acogió en su casa" (Jn 19, 25-27).

Desde la cruz, Jesús se está dirigiendo a Juan y María, de pie ante él.

\section{2.- La tierra en tinieblas (Lc 23, 44)}

"Era ya cerca de la hora sexta cuando se oscureció el sol y toda la tierra quedó en tinieblas, hasta la hora nona" (Lc 23, 44).

Es una escena llena de dramatismo. En medio de la oscuridad, una ráfaga de luz que baja del cielo, ilumina el cuerpo de Jesús crucificado. La gente está atemorizada. Algunos escapan. A la izquierda un caballo huye al galope.

\section{3.- En tus manos encomiendo mi espíritu (Lc 23, 46)}

"Jesús dando un fuerte grito dijo: Padre, en tus manos pongo mi espíritu. Y dicho esto expiró" $(\mathrm{Lc} 23,46)$.

Aunque todavía gotea sangre de las heridas de sus clavos, Jesús está ya muerto. Su cabeza y sus cabellos cuelgan sobre el pecho, por donde se ve correr la sangre.

\section{4.- La lanzada (Jn 19, 31-37)}

“... al llegar a Jesús, como le vieron y a muerto, no le quebraron las piernas, sino que uno de los soldados le atravesó el costado con una lanza y, al instante, salió sangre y agua" (Jn 19, 33-34).

$\mathrm{Al}$ introducir el soldado la lanza en el costado de Jesús crucificado, la sangre está brotando a borbotones. A la derecha aparece su madre cubriéndose el rostro. (Ilustración 83)

\section{5.- El descendimiento (Lc 15, 45-46)}

"Concedió el cuerpo a José de Arimatea, quien comprando una sábana le descolgó de la cruz,...” (Lc 15, 45-46).

En el grabado vemos a José de Arimatea que, con la ayuda de Juan, está bajando de la cruz el cuerpo muerto de Jesús. Están presentes, entre llantos, María, la Madre de Jesús y la Magdalena. 


\section{6.- El traslado al sepulcro (Mc 16, 46)}

Una vez que el cuerpo de Jesús fue descolgado de la cruz, José de Arimatea "lo envolvió en la sábana y lo puso en un sepulcro que estaba excavado en la roca" (Mc 16, 46).

Vemos a José de Arimatea, Nicodemo y Juan que están transportando al sepulcro -envuelto en una sábana blanca-, el cuerpo de Jesús. Por detrás, llorando, vienen María, la Madre de Jesús, y la Magdalena.

\section{7.- La sepultura de Jesús (Lc 23, 50-56)}

José de Arimatea colocó el cuerpo de Jesús "en un sepulcro excavado en la roca, en el que nadie había sido puesto todavía (...) Las mujeres que habían venido con él, desde Galilea, fueron detrás y vieron el sepulcro y cómo era colocado su cuerpo" (Lc 23, 53-55).

En el grabado Juan y José de Arimatea están colocando en el sepulcro el cuerpo de Jesús. A la derecha, María y un grupo de mujeres observan.

\section{8.- La guardia del sepulcro (Mt 27, 62-66)}

"Ellos fueron y aseguraron el sepulcro, sellando la piedra y poniendo la guardia” (Mt 27, 66).

Vemos a los sacerdotes ordenando a tres soldados que hagan la guardia, ante el sepulcro sellado. (Ilustración 84)

\section{9.- La resurrección (Mc 16,9)}

“Jesús resucitó en la madrugada, el primer día de la semana” (Mc 16,9).

El grabado nos muestra a Jesús saliendo del sepulcro. Su resplandor ilumina las tinieblas y asusta y deslumbra a los tres soldados que estaban de guardia.

\section{0.- Soborno a los soldados (Mt 28, 11-15)}

"Dieron una buena suma de dinero a los soldados, advirtiéndoles: Decid: Sus discípulos vinieron de noche y lo robaron, mientras nosotros dormíamos" (Mt 28, 12-13).

La imagen nos muestra a los sacerdotes entregando monedas de plata a los tres soldados que custodiaban el sepulcro.

\section{1.- El sepulcro vacío. Mensaje del ángel (Mc 16, 1-7)}

“...el primer día de la semana, a la salida del sol, van al sepulcro (...) Vieron a un joven (...) El les dijo: No os asustéis. Buscáis a Jesús de Nazaret, el crucificado. Ha resucitado. No está aquí” (Jn 16, 1-5). 
En la imagen vemos a las tres mujeres, María Magdalena, María la de Santiago y Salomé, dialogando con el joven ángel.

\section{2.- Corrieron a dar la noticia a sus discípulos $(\mathrm{Mt} 28,8)$}

"Partieron a toda prisa del sepulcro con miedo y gran gozo y corrieron a dar la noticia a los discípulos" (Mt 28,8).

Las tres mujeres que vieron el sepulcro vacío y oyeron el mensaje del ángel están entrando en el cenáculo y dan la noticia a Pedro y Juan.

\section{3.- Corriendo hacia el sepulcro (Jn 20, 3-4)}

"Salieron Pedro y el otro discípulo y se encaminaron al sepulcro. Corrían los dos juntos, pero el otro discípulo corría por delante más rápido que Pedro y llegó primero al sepulcro" (Jn 20, 3-4).

La imagen nos muestra a los dos discípulos corriendo a grandes zancadas. Juan le ha cogido la delantera a Pedro.

\section{4.- Vio y creyó (Jn 20, 6-9)}

Aunque Juan es el primero que llega al sepulcro, no entra, sino que espera a que entre Pedro. "Entonces entró también el otro discípulo (...) Vio y creyó, pues hasta entonces no habían comprendido que según la escritura, Jesús debía resucitar de entre los muertos" (Jn 20, 6-9).

En el grabado vemos a los dos discípulos, Pedro y Juan, que contemplan el sepulcro vacío y el sudario plegado encima.

\section{5.- Lo reconocieron al partir el pan (Lc 24, 1-35)}

"Sentado a la mesa con ellos, tomó el pan, pronunció la bendición, lo partió y se lo iba dando. Entonces se les abrieron los ojos y lo reconocieron, pero él desapareció de su vista (Lc 24, 28-31).

El grabado muestra el momento en el que Jesús está partiendo el pan y los discípulos de Emaús lo reconocen.

\section{6.- Corriendo hacia Jerusalén (Lc 24, 33)}

"Y levantándose al momento, se volvieron a Jerusalén" (Lc 24,33).

Los discípulos de Emaús, tras la experiencia del encuentro con Jesús resucitado, se apresuran a volver a Jerusalén. Aquí los vemos corriendo, en medio de un camino entre montañas. 


\section{7.- ¡Es verdad! Ha resucitado (Lc 24, 33-35)}

"Encontraron reunidos a los once y a los que estaban con ellos, que decían: ;Es verdad! El Señor ha resucitado y se ha aparecido a Simón. Ellos, por su parte, contaron lo que había pasado en el camino, y cómo lo habían conocido al partir el pan” (Lc 24, 35-37).

La imagen nos muestra a los discípulos de Emaús que llegan al cenáculo y son recibidos por Pedro, Juan y los demás discípulos.

\section{8.- ¡Paz a vosotros! (Lc 24, 36-40)}

"Se presentó en medio de ellos y les dijo: La paz con vosotros. Sobresaltados y asustados creían ver un espíritu (...) y diciendo esto les mostró las manos y los pies" (Lc 24, 36-40).

Este grabado muestra la gran sorpresa y alegría a la vez de los discípulos, al ver a Jesús Resucitado, que se hace presente en medio de ellos.

\section{9.- Tenéis algo de comer (Lc 24, 41-43)}

"Como no acababan de creérselo a causa de la alegría y estaban asombrados les dijo: ¿Tenéis aquí algo de comer? Ellos le ofrecieron un trozo de pescado. Lo tomó y comió delante de ellos" (Lc 24, 41-43).

La imagen muestra cómo Jesús se está llevando un bocado a la boca, mientras todos los discípulos lo están mirando fijamente.

\section{0.- Últimas instrucciones (Lc 24, 44-48)}

"Así está escrito, que el Cristo debía padecer y resucitar de entre los muertos al tercer día y que se predicaría en su nombre la conversión para el perdón de los pecados a todas las naciones, empezando desde Jerusalén. Vosotros sois testigos de estas cosas" (Lc 24, 46-48).

Jesús resucitado está dando estas instrucciones a los discípulos que le escuchan con atención.

\section{1.- Anuncio del envío del Espíritu Santo $(\operatorname{Lc} 24,49)$}

"Mirad, yo voy a enviar sobre vosotros la Promesa de mi Padre. Vosotros permaneced en la ciudad hasta que seáis revestidos del poder de lo alto” (Lc 24, 49).

Colocado frente a los discípulos, todos de pie, Jesús -con una mano tendida-, les pide que se queden en Jerusalén hasta que reciban el Espíritu Santo. 


\section{2.- Tomás no estaba con ellos (Jn 20, 24-25)}

"Tomás (...) no estaba con ellos cuando vino Jesús. Los otros discípulos le decían: Hemos visto al Señor. Pero él les contestó: Si no veo en sus manos la señal de los clavos y no meto mi mano en su costado lo creeré" (Jn 20, 24-25).

Aquí es Pedro quien le está contando a Tomás la experiencia de la aparición de Jesús. Tomás con su gesto de las manos, está indicando que rechaza admitirlo, hasta que no lo compruebe.

\section{3.- ¡Señor mío y Dios mío! (Jn 20, 26-28)}

“... Luego dijo a Tomás: Acerca aquí tu dedo y mira mis manos; trae tu mano y métela en mi costado y no seas incrédulo sino creyente". Tomás le contestó: ¡Señor mío y Dios mío! (Jn 20, 26-28).

El diseño muestra a Tomás, que, al invitarle Jesús a tocar su costado, se arrodilla ante él, confesándolo como su Dios y Señor. (Ilustración 85)

\section{4.- Id por todo el mundo (Mc 16, 14-16)}

“..se les apareció y les echó en cara su incredulidad y su dureza de corazón, por no haber creído a quienes le habían visto resucitado. Y les dijo: Id por todo el mundo y proclamad la Buena Nueva a toda la creación” (Mt 16, 14-16).

La imagen nos muestra a Jesús entre Pedro y Juan, y, delante, una gran multitud de gente, indicando la misión universal.

\section{5.- ¡Es el Señor! (Jn 21, 1-8)}

Estando en el lago de Tiberíades, después de haber pescado numerosos peces, obedeciendo la orden de Jesús, Juan dice a Pedro: “ ¿Es el Señor! Cuando Simón Pedro oyó ;Es el Señor!, se puso el vestido - pues estaba desnudo-, y se lanzó al mar” (Jn 21, 6-7).

La imagen nos muestra a Jesús a la orilla saludando a los discípulos en la barca y a Pedro que se ha lanzado al agua y va nadando hacia Jesús.

\section{6.- Les dio a comer pan y peces $(\mathbf{J n} 21,9-13)$}

"Nada más saltar a tierra ven preparadas unas brasas y un pez sobre ellas y pan (...) Jesús toma el pan y se lo da; y de igual modo el pez”"(Jn 21, 9-13).

En el grabado Jesús está asando el pescado al fuego, rodeado de Pedro y otros discípulos. 
237.- Simón, ¿me amas más que estos? (Jn 21, 15)

"Después de haber comido, dice Jesús a Simón Pedro: "Simón de Juan, ¿me amas más que estos? Le dice el: Sí, Señor, tú sabes que te quiero. Le dice Jesús: Apacienta mis corderos" (Jn 21,15).

La imagen nos muestra a Pedro dando respuesta a la pregunta de Jesús.

\section{8.- Apacienta mis ovejas (Jn 21, 16-17)}

Preguntado Pedro por tercera vez responde. "Señor, tú lo sabes todo. Tú sabes que te quiero. Le dice Jesús: Apacienta mis ovejas” (Jn 21, 16-17).

Esta imagen es muy similar a la anterior y es continuación de las preguntas de Jesús a Pedro, en presencia de los otros discípulos.

\section{9.- Estoy con vosotros hasta el fin del mundo (Mt 28, 18-20)}

"Id, pues y haced discípulos a todas las gentes, bautizándoles en el nombre del padre, del Hijo y del Espíritu Santo, y enseñándoles a guardar todo lo que os he mandado. $Y$ he aqui que estoy con vosotros todos los días hasta el fin del mundo" (Mt 28, 18-20).

En este grabado se nos muestra a Jesús imponiendo sus manos sobre los discípulos y enviándoles a la misión.

\section{0.- Seréis mis testigos (Hech 1, 6-8)}

"Seréis mis testigos en Jerusalén, en toda Judea, y Samaría y hasta los confines de la tierra" (Hech 1, 6-8).

Jesús tiene en corro, a su alrededor, a los discípulos. Les está invitando a ser sus testigos por el mundo.

\section{1.- Se fue levantando en presencia de ellos (Hech 1,9)}

" $Y$ dicho esto se fue levantando en presencia de ellos, y una nube le ocultó a sus ojos" (Hech 1,9).

Se representa la Ascensión. Jesús se está elevando al cielo en medio de un gran resplandor. Parece transportado por una nube que está bajo sus pies. Los discípulos arrodillados en tierra contemplan su partida. (Ilustración 86)

\section{2.- ¿Por qué permanecéis mirando al cielo? (Hech 1 10-11)}

"Se les presentaron de pronto dos hombres vestidos de blanco que les dijeron: Galileos, ¿por que permanecéis mirando al cielo? Este Jesús (...) volverá así tal como lo habéis visto marchar al cielo” (Hech 1, 10-11). 
En el diseño vemos a los discípulos que están escuchando con atención a los dos mensajeros vestidos de blanco.

\section{3.- Se volvieron a Jerusalén (Hech 1, 12)}

"Entonces se volvieron a Jerusalén, desde el Monte llamado de los Olivos, que está próximo a Jerusalén” (Hech 1,12).

La imagen nos muestra a la comitiva regresando a Jerusalén, después de la Ascensión de Jesús. Van en cabeza Pedro y Juan. Les siguen María y el resto de los discípulos.

\section{4.-Pentecostés (Hech 2, 1-13)}

"De repente vino del cielo un ruido como una impetuosa ráfaga de viento, que llenó toda la casa en la que se encontraban. Se les aparecieron unas lenguas como de fuego, que se repartieron y se posaron sobre cada uno de ellos; se llenaron de Espiritu Santo y se pusieron a hablar en diversas lenguas" (Hech 2,1-4).

El grabado escenifica, precisamente, este episodio. Puede verse cómo el viento entra por la ventana y mueve la cortina y una lengua de fuego se posa sobre cada uno de los presentes. (Ilustración 87)

\section{5.- Discurso de Pedro (Hech 2, 14-36)}

"Entonces Pedro, presentándose con los once, levantó la voz y dijo: (...) Israelitas, a Jesús el Nazareno (...) vosotros le matasteis clavándole en la cruz (...) a este Dios le resucitó" (Hech 2,14-24).

En el grabado, Pedro -en presencia de María y los apóstoles-, está dando este anuncio.

\section{6.- Cada uno le oía hablar en su propia lengua (Hech 2, 5-13)}

"Estupefactos y admirados decían: ¿Es que no son galileos todos estos que están hablando? Pues ¿cómo cada uno de nosotros les oímos en nuestra propia lengua nativa?" (Hech 2, 5-13).

El grabado muestra gente de distintas razas y naciones escuchando atentamente el discurso de Pedro.

\section{7.- Indicando el camino hacia Roma}

En el grabado se nos muestra un mapa del Mediterráneo en la pared, donde pueden verse el norte de África, Sicilia e Italia. Pedro está indicando a los demás apóstoles este mapa, como queriendo indicar que ha llegado la hora de que vayan hacia Roma a predicar el mensaje de Jesús. 


\section{8.- Martirio de Santiago el Menor}

Santiago fue el jefe de la iglesia cristiana de Jerusalén. Intentó convertir al sumo sacerdote Caifás, pero sin éxito. Según la Leyenda Dorada, los judíos le llevaron al pináculo del templo, le dieron un empujón y lo arrojaron al vacío ${ }^{87}$.

\section{9.- Muerte de Santiago el Menor}

Aunque fue arrojado desde lo más alto del templo, Santiago no se hizo nada. Pero los judíos se arremolinaron en torno a él y comenzaron a apedrearlo. Finalmente, con una pértiga de batanero le golpearon el cráneo y le saltaron los sesos ${ }^{88}$.

En el grabado vemos grandes piedras que le están golpeando la cabeza.

\section{0.- Crucifixión de San Pedro}

Según la Leyenda Dorada, san Pedro fue crucificado en Roma con la cabeza hacia abajo y los pies hacia arriba, por explícito deseo suyo. Él no se consideraba digno de ser crucificado en la misma postura que Cristo. En el grabado se nos muestra a Pedro crucificado y a los soldados romanos alejando a la gente con látigos ${ }^{89}$. (Ilustración 88)

\section{1.- El apóstol Felipe crucificado y lapidado}

La Leyenda Dorada asegura que, según san Isidoro, el apóstol Felipe terminó su vida en Hierápolis, ciudad de la provincia de Frigia. Murió crucificado y lapidado y allí descansan tanto él como sus dos hijas. En el grabado vemos cómo es lapidado, mientras está crucificado ${ }^{90}$.

\section{2.- El apóstol Andrés crucificado}

El procónsul Egeas del Peloponeso le reprochaba que predicase la desobediencia al emperador. Por eso, primero lo hizo azotar con varas y, des-

${ }^{87}$ VorÁgine, Santiago de la, La leyenda dorada, Alianza Editorial, Madrid 2001, p. 282; REAU, Louis, Iconografía de los santos Vol. 2, G-O, Ediciones del Serbal, Barcelona 2001, p. 185.

${ }^{88}$ VorÁgine, Santiago de la, La leyenda dorada, p. 282; REAU, Louis, Iconografía de los santos Vol. 2, p. 185.

${ }^{89}$ VorÁgine, Santiago de la, La leyenda dorada, p. 352; REAU, Louis, Iconografía de los santos Vol. 3, p. 66.

${ }^{90}$ VorÁGINE, Santiago de la, La leyenda dorada, p. 277; REAU, Louis, Iconografía de los santos Vol. 1, p. 510. 
pués, ordenó que lo atasen con cuerdas a una cruz en forma de X. Habría agonizado durante dos días en la cruz y expirado al tercero. En el grabado se le representa crucificado con clavos, en lugar de atado con cuerdas ${ }^{91}$.

\section{3.- El apóstol Mateo apuñalado}

Según la Leyenda Dorada, el rey Hirtaco de Etiopía quiso casarse con su sobrina Ifigenia, virgen consagrada al Señor. Cuando Mateo se opuso, decidió matarlo. Mientras estaba celebrando la misa, un sicario, enviado por el rey, le clavó una espada en la espalda y le mató. Este motivo es el que representa el grabado ${ }^{92}$.

\section{4.- Santiago el Mayor decapitado}

Se suponía que había predicado la fe en Siria y Judea y -según la tradición española-, también en España. Regresado a Jerusalén en el año 44, habría sido decapitado por orden de Herodes Agripa, siendo uno de los primeros mártires de Cristo.

En el grabado vemos a unos soldados romanos decapitándole ${ }^{93}$.

\section{5.- San Juan dentro del caldero}

Según la leyenda, el emperador Domiciano -dado que Juan se negaba a ofrecer sacrificios a los ídolos-, le condenó a ser sumergido en una caldera de aceite hirviendo, ante la Puerta Latina de Roma. Pero el santo salió sin la menor quemadura, fresco, y hasta rejuvenecido. El grabado nos lo muestra cuando está sufriendo esta tortura ${ }^{94}$.

\section{6.- El apóstol Bartolomé desollado}

Según la leyenda habría evangelizado en Arabia, Mesopotamia y Armenia, Fue allí donde -según el martirologio romano-, le habría desollado vivo por orden del rey Astiajes, enfurecido porque Bartolomé habría con-

${ }^{91}$ Vorágine, Santiago de la, La leyenda dorada, p. 34; REAU, Louis, Iconografía de los santos Vol. 1, p. 82.

${ }^{92}$ VorÁgine, Santiago de la, La leyenda dorada, p. 604; REAU, Louis, Iconografía de los santos Vol. 2, p. 371.

${ }^{93}$ VorÁGIne, Santiago de la, La leyenda dorada, p. 399; REAU, Louis, Iconografía de los santos Vol. 3, p. 170.

${ }^{94}$ VorÁgine, Santiago de la, La leyenda dorada, p. 295; REAU, Louis, Iconografía de los santos Vol. 2, p. 193. 
vertido al cristianismo a gran número de sus vasallos. El grabado nos muestra el momento en el que le están desollando ${ }^{95}$.

\section{7.- Muerte del apóstol Tomás, alanceado}

Según la leyenda, Tomás habría evangelizado en la India y, tras su muerte, estaría enterrado en Meliapur, cerca de Goa. El grabado muestra cómo murió: alanceado por sacerdotes paganos. Antes había sido sometido a otras torturas. Una de ellas fue meterlo en un horno ardiendo, pero, milagrosamente, el horno se apagó ${ }^{96}$.

\section{8.- Cristianos arrojados a los leones}

Vemos en el grabado la persecución de los cristianos en Roma. Dentro del Coloseo algunos son crucificados. Otros están orando, alrededor de un anciano con los brazos levantados. Todos van a ser devorados por un grupo de leones, que se están abalanzando sobre ellos.

\section{9.- Cristiano decapitado en China}

En una plaza china llena de gente, dos verdugos están decapitando a un cristiano sobre un estrado. Este se encuentra arrodillado y maniatado. Luce una cruz en el pecho de su túnica. Un verdugo le está tirando de los pelos. El otro está a punto de cortarle el cuello con una espada.

\section{0.- Caminando hacia la cruz}

El grabado nos muestra, a un lado una esfera terrestre. De ella están saliendo en procesión todo tipo de personas, que se están encaminando hacia la cruz. Es una representación simbólica que indica la vocación universal del cristianismo.

\section{1.- La defensa de los débiles}

En el grabado se ve enfrentados a dos personajes. El de la izquierda, con turbante, tiene un palo en la mano, con el que está amenazando, y un puñal en la cintura. El de la derecha -un misionero cristiano-, está con los brazos extendidos protegiendo a unas personas que están detrás de él.

\footnotetext{
${ }^{95}$ VorÁGIne, Santiago de la, La leyenda dorada, p. 527; REAU, Louis, Iconografía de los santos Vol. 1, p. 180.

${ }^{96}$ VorÁgine, Santiago de la, La leyenda dorada, p. 51; REAU, Louis, Iconografía de los santos Vol. 3, p. 270.
} 


\section{2.- La consagración a María}

Un misionero católico, vestido con roquete, está celebrando la consagración a la Virgen María de una madre china y su hija. Las dos están de pie ante el sacerdote, que está realizando la bendición. Detrás, en medio de ellos, se encuentra una imagen de María Inmaculada.

\section{3.- Dar de comer al hambriento}

Una de las obras cristianas de misericordia es "dar de comer al hambriento". En el grabado vemos a un misionero que está entregando un cuenco de arroz a un mendigo con muletas. Una sombra detrás, insinúa la silueta de Cristo, indicando que, para los cristianos, Cristo se identifica con el pobre.

\section{4.- Promoción de la agricultura}

$\mathrm{Al}$ fondo se ve la imagen de un monasterio. En primer plano se encuentra un monje cultivando los campos. Con ello se quiere indicar que el cristianismo promovió la agricultura en China.

\section{5.- Promoción de la sanidad}

Dentro de un hospital, en el que hay cuatro enfermos en la cama, vemos a un fraile cristiano que está dando de comer a uno de ellos. Indica que el cristianismo promovió en China la sanidad.

\section{6.- Promoción del arte}

Con la imagen de una catedral gótica se quiere simbolizar que el cristianismo, en todo el mundo, ha promovido el arte y la arquitectura.

\section{7.- Promoción de la educación}

El diseño nos presenta a un fraile en una cátedra y, en los asientos, a diversos alumnos estudiando. Se quiere ilustrar cómo la fe cristiana fue promotora de la educación y la cultura.

\section{8.- Promoción de las universidades}

El grabado muestra un hermoso edificio chino coronado con una cruz. Con ello se quiere indicar que la religión católica fue promotora de universidades en China, concretamente en Pekín. 


\section{9.- Promoción de la ciencia}

Vemos en el dibujo a un joven analizando unos termómetros y unos aparatos científicos. Se quiere ilustrar, de este modo sencillo, cómo la religión cristiana fue promotora de la ciencia.

\section{0.- Una nueva era}

Una multitud de chinos están mirando un calendario de números que termina en 1950 y se remonta en el otro extremo hasta la cruz. Con esta imagen se quiere indicar que la religión católica abrió una nueva era para la humanidad.

\section{1.- Obras de misericordia}

Con varios pequeños diseños entre nubes, se quieren ilustrar las obras de misericordia promovidas por los católicos en China: dar de comer al hambriento; enseñar al que no sabe; visitar a los encarcelados; curar a los enfermos,...

\section{2.- El bautismo}

El sacramento cristiano del bautismo es representado con una mano que derrama agua sobre la cabeza de un varón concentrado en oración.

\section{3.- La confirmación}

El sacramento cristiano de la confirmación es representado con una mano que está ungiendo la cabeza de un hombre joven.

\section{4.- Sacramento de la penitencia}

El sacramento de la penitencia es representado como un hombre arrodillado frente a una celosía que está confesando sus pecados. Al otro lado se puede apreciar la sombra del sacerdote que está escuchando.

\section{5.- Sacramento de la eucaristía}

Un hombre mayor, con barba y pelo blanco, recibe devotamente con las manos juntas, la comunión que le está entregando en la boca la mano de un sacerdote.

\section{6.- Sacramento del matrimonio}

El sacramento del matrimonio es representado como el rito del intercambio de las alianzas. Una mano masculina está colocando un anillo en el dedo anular de una mujer. 


\section{7.- Sacramento del sacerdocio}

El sacramento del orden sacerdotal está representado con dos manos juntas que -una vez ungidas con óleo santo-, las han atado con un paño. De frente se ve el báculo episcopal sostenido por la mano del obispo que ordena.

\section{8.- Sacramento de la unción de los enfermos}

El sacramento de la unción de los enfermos es representado con el rostro de un anciano con barba tendido en el lecho, que está recibiendo de la mano de un sacerdote, la unción en la frente.

\section{9.- Buscar a Cristo}

En el diseño vemos a un sacerdote o catequista que está instruyendo a un niño. El texto chino que está al lado habla de los siete sacramentos e invita a buscar a Cristo.

\section{III.- CONCLUSIÓN}

Los misioneros cristianos, siguiendo la tradición secular, fueron conscientes de la importancia del uso de las imágenes como medio de evangelización. Por su parte, los misioneros agustinos de la provincia de Hunan septentrional -además de utilizar los catecismos con solo texto, para enseñar las verdades cristianas y la vida y enseñanzas de Jesús-, utilizaron también catecismos con ilustraciones y grabados. Las tres obras que hemos estudiado son una pequeña muestra de ello.

Como se ha destacado ya, en la presentación a los chinos del mensaje cristiano en imágenes durante la primera mitad del siglo XX, se podría hablar de un proceso de "sinización", de encarnación en el mundo chino. Se da una evolución desde modelos fundamentalmente europeos a modelos propiamente chinos, que podríamos dividir en tres fases.

En un primer momento -representado por la obra "La Historia Sagrada" de 1920-, todos los diseños están inspirados en modelos europeos. Los grabadores chinos no hacen más que copiarlos y reproducirlos fielmente.

En una segunda fase -representada por la obra "Catecismo chino en láminas policromadas”, impresa hacia 1925-, una mitad de las obras están inspiradas en modelos europeos y los siguen fielmente, como hemos visto. 
La otra mitad, la realización es ya obra de autores chinos. Así nos lo muestran claramente los diseños de los rostros de los personajes, la vestimenta, el paisaje, ...

En una tercera fase -representada por la obra "La historia más famosa" de 1950-, nos encontramos que tanto el autor del texto como el autor de los dibujos grabados son chinos. Podríamos hablar de una completa "sinización" de la historia de Jesús. No obstante, hay que reconocer que el artista chino Chen Guanyi es bien consciente que está contando una historia de personajes hebreos, en la época del imperio romano. Es decir, que no ha "achinado" a los personajes, sino que es un artista chino que representa a personajes del Medio Oriente, con vestimentas propias de la época. Donde más se nota el influjo del arte chino es en la representación de los paisajes.

Hay que constatar que en esta publicación "La Historia más grande" tanto el autor del texto, Chen Wanli, como el autor de las imágenes, Chen Guanyi, muestran una gran familiaridad con los cuatro evangelios -Mateo, Marcos, Lucas y Juan-, y consiguen presentar una síntesis progresiva bien articulada y convincente de la vida de Jesús. Al mismo tiempo nos muestran que están también al corriente de la tradición cristiana y de leyendas que se encuentran en la obra "La Leyenda Dorada". Esto puede verse principalmente a la hora de representar los diversos martirios de algunos de los apóstoles, de los que no tenemos conocimiento en los textos canónicos, pero de los que sí se habla en la citada obra.

Hoy día, en el siglo XXI, el mundo de la imagen ha evolucionado extraordinariamente por medio de las nuevas tecnologías, la informática, Internet, las redes sociales, etc. Si se quiere llegar a la gran masa de población de 1370 millones de chinos será necesario utilizar estos nuevos medios de comunicación y transmisión de la imagen. Todo un reto si pensamos que el cristianismo en China representa, actualmente, sólo el 0’7 de la población. 

IV.- ILUSTRACIONES 